Licentiatavhandling

\title{
Samtals- och skriftspråksorienterade lärarledda aktiviteter i förskoleklass
}

Christina Aminoff

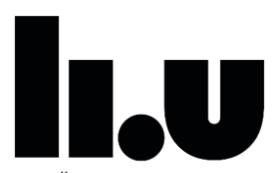

LINKÖPINGS UNIVERSITET

Institutionen för beteendevetenskap och lärande Linköpings universitet

LiU-PEK-R-265

Mars 2017 


\section{LINKÖPINGS UNIVERSITET \\ Institutionen för beteendevetenskap och lärande}

LiU-PEK-R-265

ISBN 978-91-7685-556-0

Linköpings universitet

Institutionen för beteendevetenskap och lärande SE-581 83 Linköping, Sweden

Tel 013-28 1000

Tryck: Linköpings universitet, LiU-Tryck 2017 


\section{Förord}

Det är många personer som har haft en stor betydelse för att det nu finns en färdig text att läsa och som jag vill rikta ett stort och varmt tack till. Det är med tacksamhet jag tänker på alla er lärare och barn som deltagit i studien. Ni har vid varje klassrumsbesök låtit mig ta del av er vardag på ett mycket generöst sätt.

Ett djupt och innerligt tack vill jag rikta till mina handledare, Karin Forslund Frykedal och Marianne Skoog. Vad vore denna licentiatuppsats utan er! Med stort engagemang och till synes outtröttliga har ni gripit er an och kommenterat utkast efter utkast. Era synpunkter och våra samtal har varit ovärderliga!

Jag vill också uttrycka min tacksamhet till Styrelsen för utbildningsvetenskap vid Linköpings universitet och Torsten Söderberg stiftelse som bidragit med finansiellt stöd och därmed gjort det möjligt att genomföra denna studie.

Tack Elisabeth Mellgren för att du granskade mitt manus vid mitt halvtidsseminarium. Det gav mig inspiration att fortsätta skriva på diskussionskapitlet.

Ett stort tack vill jag rikta till mina kolleger vid PEDI, särskilt svenskdidaktikgänget Åsa Elwér, Stefan Gustafson, Magnus Jansson, Annika Mindedal, Ulla-Britt Persson, och Anja Thorsten. Ni har läst och kommenterat manus som bidragit till värdefull utveckling av arbetet. Tack också för alla uppmuntrande ord och den omtanke ni visat mig under resans gång. Ett stort tack riktas även till Margareta Engvall och Cecilia Sveider för den stöttning och omtanke ni visat under hela processen.

Slutligen vill jag uppmärksamma och tacka min underbara härliga familj Pierre, Victoria och Filip. Alla dessa samtal... det vet i sjutton om jag fixat detta utan er. Tack för att ni finns och tror på mig!

Linköping, mars 2017

Christina Aminoff 


\section{Förord}

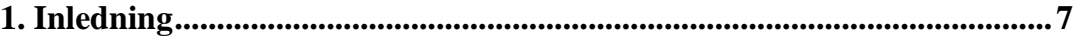

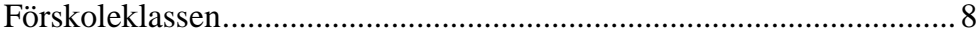

Förskoleklassens tillkomst ...................................................... 8

Resultat av intentionen med förskoleklassen ............................ 10

Förskoleklassverksamheten......................................... 10

Samverkan mellan personalkategorierna ...................... 11

Lärares och barns uppfattningar om förskoleklassen.... 12

Samtals- och skriftspråksorienterade aktiviteter ........... 12

En bild av otydlighet............................................................ 14

Studiens syfte och frågeställningar ................................................... 17

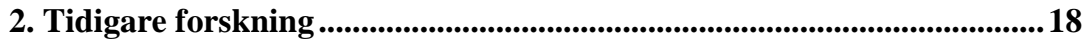

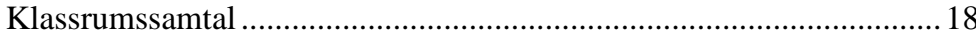

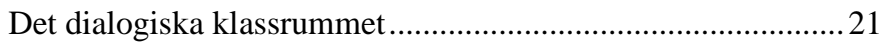

Faktorer av betydelse för läs- och skrivutvecklingen ........................... 23

Att läsa och skriva ............................................................................. 26

En balanserad läs- och skrivundervisning ........................................... 29

Högläsning och samtal om texter ....................................................... 30

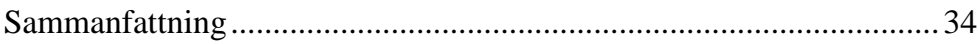

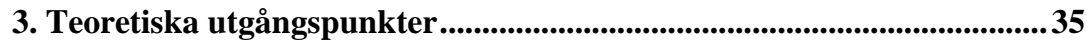

En sociokulturell syn på lärande och utveckling .................................. 35

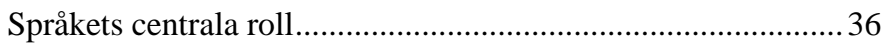

Närmaste utvecklingszonen och stödstruktur ........................... 37

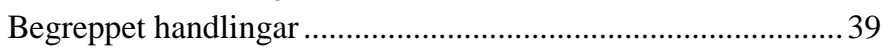

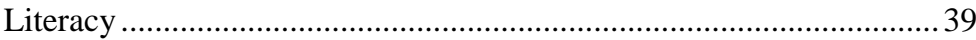

Literacy som social aktivitet ..................................................... 40

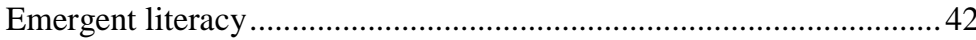

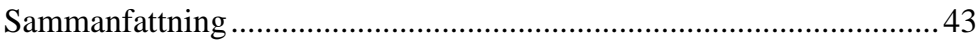

Det sociokulturella perspektivet i denna studie .................................. 43

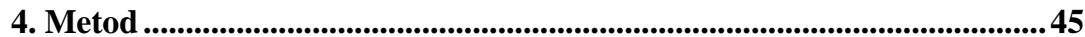

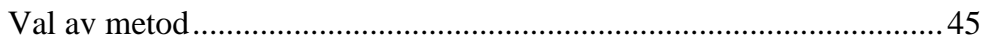

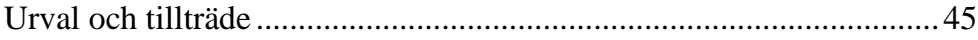

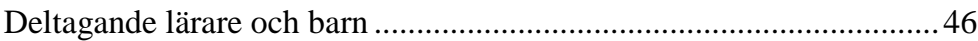

Delvis deltagande observation ................................................................46

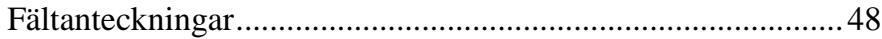

Dokument och informella samtal........................................................ 49

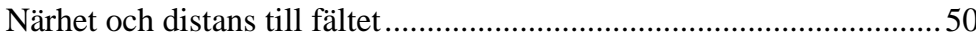

Analys av det empiriska materialet.................................................... 51

Kvalitetsaspekter i forskningsprocessen..............................................54 


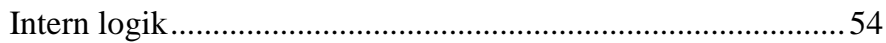

Forskningsetiska överväganden ........................................... 54

5. En presentation av studiens förskoleklasser ..........................................56

Lärarna och barnen ........................................................................... 56

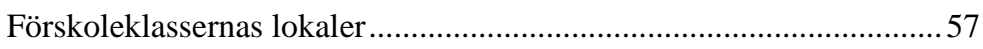

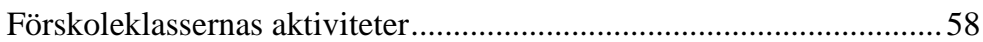

Morgonsamling med berättarstund ....................................... 58

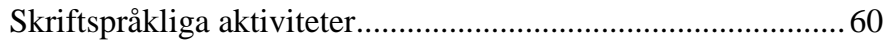

Matematikaktiviteter .............................................................6 60

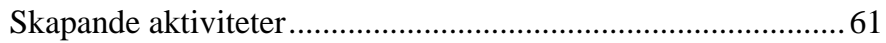

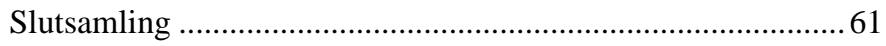

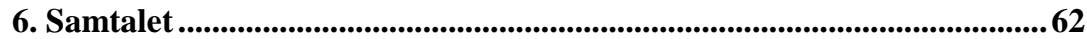

Samtalets möjligheter och begränsningar ............................................ 62

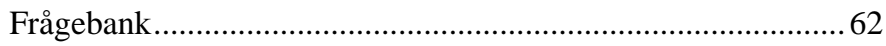

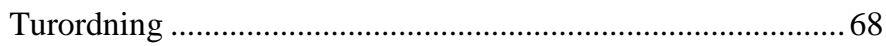

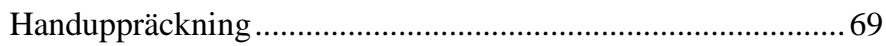

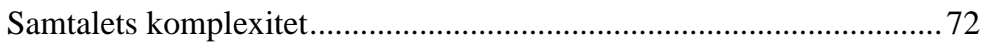

Barnet tar initiativ till att delta i samtalet................................ 72

Läraren tar initiativ till samtal med barnen............................... 74

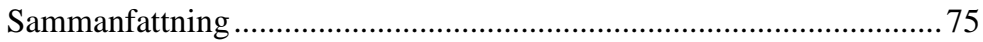

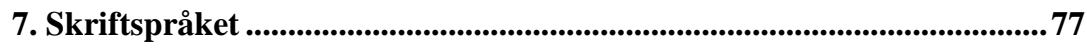

Arbete med den grammatiska koden ................................................. 77

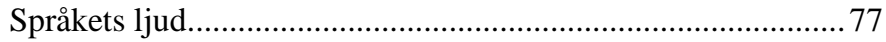

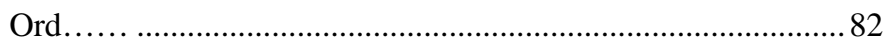

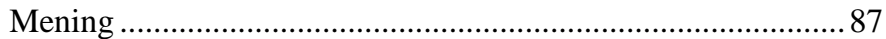

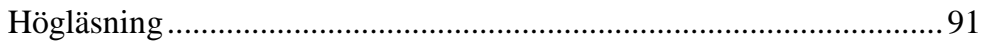

Läsa med avbrott.............................................................. 92

Läsa utan avbrott.................................................................. 95

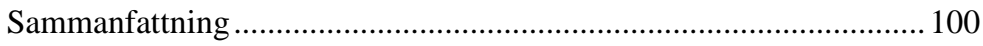

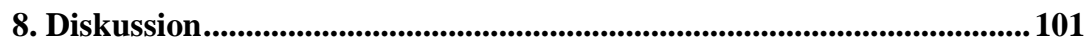

Metodiska reflektioner................................................................. 101

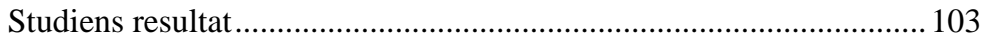

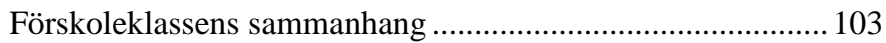

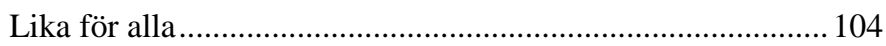

Högläsning - att röra sig i texter på olika sätt ......................... 107

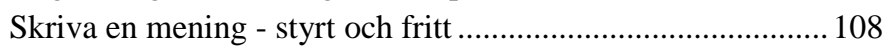

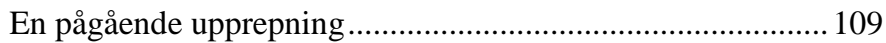

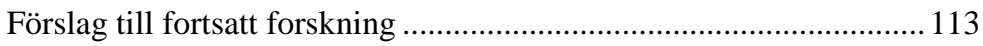


9. Referenser..

115

Tidigare utgivna rapporter 


\section{Inledning}

Detta är en studie om samtal och skriftspråklighet i förskoleklassen. Förskoleklassen är en egen skolform mellan förskola och skola. Här arbetar lärare och barn tillsammans under ett läsår och vanligen skiljs de åt när barnen tar steget in i årskurs 1 och möter en ny lärare.

Förskoleklassen är tänkt att fungera som en bro mellan förskolans och skolans pedagogiska traditioner (Proposition, 1997/98:6). Den ska binda samman verksamheten i förskolan, grundskolan och fritidshemmet för att därigenom öka kvaliteten i alla verksamheterna (Skolverket, 2001). En del av det verksamhetsuppdrag som förskoleklassen har är att förbereda barnen för skolan (Proposition, 1997/98:6), vilket gör att året kan ses som en viktig del av barnens liv och som även kan få betydelse för dem i ett längre tidsperspektiv. Att möta, stödja och utveckla barns språk, läsande och skrivande är delar av ett sådant verksamhetsuppdrag. I skolans styrdokument formuleras det på följande sätt: "Språk, lärande och identitetsutveckling är nära förknippade. Genom rika möjligheter att samtala, läsa och skriva ska varje elev få utveckla sina möjligheter att kommunicera och därmed få tilltro till sin språkliga förmåga” (Skolverket, 2016, s. 9). Utvecklingen av ett barns språkliga förmåga startar emellertid tidigare, redan i förskoleåldern genom att de deltar i olika språkliga sammanhang (Fast, 2007). Barnen kommer således till förskoleklassen med olika erfarenheter av att delta i samtal, läsande och skrivande.

Förskoleklassen har haft en ganska oklar roll som därför behöver förtydligas (Skolverket, 2009; SOU 2010: 67). En central fråga blir då vad som sker i denna verksamhet när ljuset riktas mot samtalandet, läsandet och skrivandet. För att undersöka detta närmare kommer i denna studie de samtals- och skriftspråksorienterade lärarledda aktiviteter som sker i förskoleklassen att vara i fokus. Aktiviteterna studeras genom deltagarnas handlingar i tal och skrift, samt genom deras fysiska handlingar såsom gester och ansiktsuttryck. Handlingarna kommer till uttryck genom de sätt som lärare och barn och barn sinsemellan interagerar med varandra, men också genom deras sätt att interagera med den omgivande fysiska miljön. Enligt Säljö (2000) bidrar människors handlingar till att återskapa eller omskapa den verksamhet som de utförs i. I denna studie innebär det att de handlingar som sker från deltagarnas sida också bildar den verksamhet som studeras. Då studien riktas mot de handlingar som skapar verksamheten i förskoleklassen blir det intressant att först ta del av statens intentioner med införandet av förskoleklassen, vilka därför kommer att beskrivas i nästa avsnitt. Därefter skildras vilket genomslag dessa intentioner fått i praktiken. Kapitlet avslutas med studiens syfte och frågeställningar. 


\section{Förskoleklassen}

I politiska sammanhang har det i decennier diskuterats vid vilken ålder ett barn ska börja skolan och under lång tid har 7 år ansetts vara en lämplig ålder. På senare år har frågan intensifierats och diskussioner om att tidigarelägga skolstarten återkommer med jämna mellanrum i den politiska debatten. Inte minst med tanke på att den svenska skolstartsåldern anses som hög om man ser till ett internationellt perspektiv. En annan fråga som diskuterats mycket handlar om hur många år den obligatoriska skolan ska sträcka sig över, vilket sedan 1962 är nio år (SOU 2010:67). En nordisk jämförelse visar exempelvis att den danska motsvarigheten till den svenska förskoleklassen benämns "bornehaveklasse”. Här börjar barnen när de är cirka 6 år och den är obligatorisk. Det blir barnens första möte med skolan som i Danmark sammanlagt är på tio år. Också i Norge går barnen i skolan i tio år och de börjar det första året i det så kallade ”barnetrinnet” vid sex års ålder. Detta första år är också obligatoriskt för alla barn (SOU 2015:81). Enligt Sandberg (2012) kan den svenska förskoleklassen anses vara ganska ensam i sitt slag då den är en egen och frivillig skolform, inte har några uppnåendemål, och oftast bemannas av förskollärare. Många länders första skolår kan ändå sägas likna den svenska förskoleklassverksamheten till sitt innehåll, då undervisningen bygger på lek och skapande (Sandberg, 2012).

Förskolan och skolan baserar sig på olika traditioner och har olika syn på lärandet. Ett här- och nu perspektiv präglar förskolans kultur på lärande till skillnad från skolans där tonvikten ligger på ett långsiktigt, systematiskt och strukturerat lärande. Förskolan kan sägas ha en mer socialt inriktad verksamhet jämfört med grundskolan som har en mer kunskapsinriktad verksamhet (Proposition 1997/98:6; SOU 2010:67).

Den sexårsverksamhet som tidigare bedrivits inom ramen för förskolan blev 1 januari 1998 en egen skolform inom det offentliga skolväsendet. Skolformen fick benämningen förskoleklass och det är här som förskolans och grundskolans olika uppdrag och traditioner är tänkta att mötas och utvecklas (SOU 2010:67).

\section{Förskoleklassens tillkomst}

Den statliga intentionen med förskoleklassen var att förskolan, skolan och fritidshemmets pedagogiska verksamheter skulle mötas och bilda en gemensam pedagogisk helhet (Proposition 1997/98:6). Tanken var att genom förskoleklassen få till en ökad integration mellan förskola och skola och att den skulle ligga till grund för en fortsatt skolgång. Betydelsen av samverkan mellan de skilda personalkategorierna inom de olika verksamheterna lyftes fram. I förskoleklassen skulle förskollärare, grundskollärare och fritidspedagoger gemensamt bidra med sitt 
professionella kunnande och sina respektive traditioner (Proposition, 1997/98:6). Lärarnas kunskaper beskrivs i förskoleklassen som något som inte finns inom den sedvanliga förskolepedagogiken, men det poängteras också att det finns kunskaper som lärare i grundskolan traditionellt inte har och som är nödvändiga i förskoleklassarbetet (SOU 2008:109).

I förskolans tradition har det enskilda barnets utveckling stått i centrum. Lek, skapande, omvårdnad och omsorg, samt barns eget utforskande vid temainriktade projekt skulle nu även bli en del av skolans verksamhet samtidigt som barnen skulle förberedas för fortsatt lärande (Proposition 1997/98:6). Implementeringen av förskolepedagogiken i skolan skulle således också förändra skolans sätt att arbeta vilket skulle möjliggöra en närmare integration mellan förskolans och skolans verksamheter (Pérez Prieto, Sahlström, \& Melander, 2003).

När olika traditioner möts kan konflikter uppstå, inte minst när traditioner delvis har olika syn på barnet (SOU 1997:21). Inom förskolans tradition har synen på barnet varit att "allt finns i barnet” och barnet måste få frihet att uttrycka sig och utvecklas. Skolans tradition bygger på att förmedla och återskapa kultur. Traditionen är ämnesfokuserad och verksamhetens innehåll fastställs i högre grad av andra än barnet om man jämför med förskolan (Pérez Prieto et al., 2003; SOU 1997:21). Genom att fokusera på gemensamma mål och bygga på de olika kunskaper och erfarenheter som finns inom de båda verksamheterna förskola och skola, skulle en ny praktik och ett nytt pedagogiskt förhållningssätt utvecklas i och med förskoleklassen. Verksamheten skulle på så sätt också bli mer likvärdig för alla sexåringar i Sverige (SOU 1997:21).

För att underlätta implementeringen av förskolepedagogiken integrerades också förskoleklassen i lokaler inom grundskolans verksamhet. Det bestämdes att alla sexåringar ska ha rätt att gå i förskoleklass och att kommunerna skulle bära ansvaret för att verksamheten anordnas (Proposition 1997/98:6; Proposition 1997/98:94). Som nämnts tidigare är förskoleklassen till skillnad från grundskolan en frivillig skolform som de allra flesta barn väljer att delta i (Pérez Prieto et al., 2003). Läsåret 2014/2015 gick 95 \% av alla Sveriges sexåringar i förskoleklass (Skolinspektionen 2015:03). En viktig faktor vid inrättandet av förskoleklassen var att den inte skulle ses som det första året på en tioårig skola. Avsikten var att ge en tioårig pedagogisk verksamhet där barnen ska gå ett år i förskoleklass och nio år i grundskolan alternativt tio år i särskolan eller specialskolan (Proposition 1997/98:6).

Som en följd av inrättandet av förskoleklassen beslutades att en gemensam läroplan skulle införas för det obligatoriska skolväsendet, förskoleklassen och fritidshemmet, Lpo94 (Proposition, 1997/98:6). En reviderad version av Lpo94 började därför gälla från och med 1 augusti 1998. Under denna tid fick även förskolan sin egen läroplan, Lpfö98. En 
avsikt med de två läroplanerna, (samt även den senare tillkomna läroplanen för grundskolan, förskoleklassen och fritidshemmet, Lgr11 från 2011, reviderad 2016 och de reviderade versionerna av Lpfö98 från 2006 och 2016, min kommentar), var att de skulle överensstämma med varandra i förhållande till synen på kunskap, utveckling och lärande. Övergången mellan förskola, förskoleklass och skola skulle i och med det kunna göras på ett mjukt och följsamt sätt. Förskoleklassen är därför tänkt att fungera som en bro mellan förskola och skola (Proposition, 1997/98:6). Även inför den nya skollagen 2010 lyfts vikten av att barnen får en mjuk start in i skolans verksamhet. Inför den nya skollagen framhålls också att det är i förskoleklassen som förskolans och skolans traditioner ska mötas och utvecklas. En annan ståndpunkt som framhävs är att lärandet sker hela tiden och överallt och inte bara i planerade situationer (Proposition 2009/10:165). För att underlätta integrationen mellan förskola och skola hade man även ett par år innan reformen överfört myndighetsansvaret för förskoleverksamhet och skolbarnsomsorg från Socialdepartementet till Utbildningsdepartementet (Proposition 1997/98:6).

\section{Resultat av intentionen med förskoleklassen}

Det finns emellertid forskningsprojekt och rapporter som visar på skilda resultat när det gäller hur väl intentionen med förskoleklassen lyckats.

\section{Förskoleklassverksamheten}

Förskoleklassen har gått mot att vara mer skola där lektioner, raster och ämnen fått stort utrymme enligt Skolverkets rapport (2001). Värden som lek, skapande och barns eget utforskande har då fått komma i skymundan. Rapporten visar att skolans lokaler inte är anpassade till sexåringars rörelsebehov, vilket inneburit att alla aktiviteter inte gått att genomföra. Att undervisningen i förskoleklass liknar skolans upplägg visar även det så kallade FISK-projektet (Förskola och Skola i Samverkan). Projektet utgick ifrån fleråriga studier där barn följts från förskola till förskoleklass och årskurs 1. Även föräldrar- och lärarintervjuer ingick i projektet. Resultatet pekar på att aktiviteterna blivit alltmer vuxenstyrda i förskoleklassen och att de innehåller en ökning av inslag där bokstäver och siffror ingår, samt att barnens individuella ansvar ökat genom att de förväntas göra rätt saker på rätt sätt. Dessutom framhålls att dagen blivit mer uppdelad i olika pass vilket kan sägas efterlikna skolans organisering av verksamheten. Detta betyder att skolstarten i praktiken sker i övergången mellan förskola och förskoleklass istället för som det var tänkt med reformen, mellan förskoleklass och årskurs 1 (Pérez Prieto et al., 2003) (se även Simeonsdotter Svensson, 2009). Ett delvis annat resultat än att 
förskoleklassen kommit att bli "skolifierad" framkommer i en avhandling av Lago (2014). I den studien skildras förskoleklassen mer som en blandning av förskole- och skollika inslag.

Lärande genom lek utmärker ofta undervisningen i förskoleklass, men den "fria leken” förekommer i för stor utsträckning utan lärarnas aktiva stöd och ledning visar en kvalitetsgranskningsrapport från Skolinspektionen (2015:03). Av rapporten framkommer även att undervisningen är varierad och välstrukturerad. Undervisningen genomförs på ett sådant sätt att ingen riskerar att känna sig misslyckad i sitt lärande, men undervisningen behöver anpassas mer med hänsyn till varje barns förutsättningar och behov.

\section{Samverkan mellan personalkategorierna}

Studier och rapporter tyder på att samverkan mellan de olika personalkategorierna i förskoleklass och skola har ökat i ringa omfattning. För lite tid till planering och diskussion har gjort integrationen svårare konstaterar Skolverket (2000; 2001). Liknande resultat framkommer i en studie gjord av Fast (2007) som visar att ett gott samarbete mellan förskoleklass och skola uteblivit eftersom de olika personalkategorierna haft svårt att få tid till gemensamma samtal och planeringar. Även Sandbergs (2012) avhandling visar att det saknas ett gemensamt didaktiskt arbete mellan lärarna i förskoleklass och årskurs 1 (se även Ackesjö, 2010; Skolinspektionen, 2015:03).

Det finns emellertid forskning som tyder på att ett samarbete sker. Genom observationer och intervjuer med lärare i förskolan, förskoleklassen och skolan visar Gannerud och Rönnermans (2006) avhandling att både ett formellt och informellt samarbete sker mellan och inom de olika praktikerna. I det formella samarbetet finns särskild tid avsatt för möten där planering, diskussioner och utvärdering av verksamheten sker. Det informella samarbetet sker på personalens eget initiativ utifrån de behov som finns. Davidsson (2002) har i sin avhandling följt fyra arbetslag på två skolor med start från förskoleklass och cirka tre år framåt. Med hjälp av observationer och intervjuer med lärare och rektorer visar Davidsson att de olika traditionerna från förskola och skola kan få olika genomslagskraft beroende på hur lärarna organiserar sitt arbete. Arbetslag som är fast i den traditionella rollfördelningen mellan förskollärare och grundskollärare lyckas mindre bra med den pedagogiska integrationen jämfört med arbetslag som utgår ifrån vars och ens erfarenheter och sedan bygger vidare på dessa. Att skapa en organisation där tid ges för utbyte av erfarenheter visar sig således vara betydelsefullt. 


\section{Lärares och barns uppfattningar om förskoleklassen}

Att barn och lärare i förskoleklass har en känsla av att varken höra hemma i förskolans eller skolans värld framkommer i en rad studier. I en studie om lärares identitetskonstruktioner i förskoleklassen beskriver Ackesjö (2010) förskoleklassen som en ö eftersom den befinner sig någonstans mitt emellan förskola och skola. Hon har genom dialogseminarier med lärare i förskoleklass påvisat identitetsarbetets paradox. Lärarna talar om sin roll och om arbetet i förskoleklassen som "något annat" än förskoleverksamhet eller skolverksamhet. Lärarna menar att de inte sysslar med att undervisa barnen såsom vi traditionellt tänker oss skolans undervisning, utan allt sker på ett "annorlunda" och mer lekfullt sätt. Det framkommer också att det både finns en önskan och ett motstånd att bli inkluderade i det som skolan står för från lärarnas sida. I Fasts (2007) studie verkar både de förskollärare som arbetar i förskolan och de som arbetar i förskoleklass uppleva en vilsenhet beträffande förskoleklassens uppdrag. Är förskoleklassen förskola eller skola? Eller inte något av det, undrar Fast efter att ha summerat lärarnas tankar. Lago (2014) har i sin avhandling följt tre barngrupper och deras lärare från förskoleklass och in i årskurs 1 . Analysen av de observationer och samtal som förts med deltagarna visar att barnen uppfattar förskoleklassen som någonting mitt emellan förskola och skola, en slags mellanklass. Året i förskoleklass beskrivs som ”...ett både och eller varken eller, där barnen inte längre var förskolebarn men inte ännu skolbarn” (Lago, 2014, s. 176). Verksamheten i förskoleklass visar sig ha både likheter och skillnader från det som händer i förskolan och skolan. I lärarnas berättelser framkommer att de talar om förskoleklassen och skolan på olika sätt. Skolan står för det som är svårt och tråkigt, medan leken mer lyfts fram som något roligt och något som görs i förskoleklassen. Även i barnens berättelser framställs skolan som tråkig, trots att de inte har påbörjat sitt första år i grundskolan (Lago, 2014).

\section{Samtals- och skriftspråksorienterade aktiviteter}

Att ta barnets perspektiv visar sig problematiskt för de flesta av lärarna som arbetar i de förskoleklasser som Simeonsdotter Svensson (2009) studerat. Hon har undersökt barns olika sätt att erfara och hantera svårigheter inom förskoleklassens pedagogiska samling, det vill säga den aktivitet som vanligen inleder dagen. Studien visar att kommunikationen i den pedagogiska samlingen utgår från den vuxnes perspektiv och från den vuxnes sätt att tänka om vad som är angeläget att svara i en given situation. Flertalet av lärarna har ett fokus mot att barnen ska avge rätt eller fel svar snarare än att väcka intresse och engagemang hos barnen. Lärarens fokus mot rätt eller fel svar skapar osäkerhet hos barnen och en viss frustation eftersom de inte alltid vet vad som förväntas av dem. Kommunikationen får 
mindre utrymme och barnens delaktighet i den pedagogiska samlingen blir i mångt och mycket begränsad.

Fast (2007) har följt sju barn under tre års tid från det att barnen fyllde fyra år. Studiens resultat visar att barnen praktiserar läsande och skrivande långt innan den formella läs- och skrivundervisningen tar vid. När barnen kommer till förskola och skola har de stora erfarenheter av läsande och skrivande från bland annat hemmiljö och medier med sig. Somliga barn har möjligheten att ta med sig sina erfarenheter in i klassrummet medan andra inte ges den chansen. Studien visar att den läsinlärning och bokstavsinlärning som sker i förskoleklass och årskurs 1 sker på ett traditionellt sätt där man arbetar med en bokstav i taget. Studien visar också att övningar från förskoleklassen många gånger upprepas i årskurs 1. De lärare som tar över barnen i årskurs 1 verkar veta mycket lite om vad barnen arbetat med i förskoleklass. En progression i lärandet kan därmed enligt Fast utebli.

Att förskoleklassens övningar upprepas i årskurs 1 framkommer även i Skoogs (2012) avhandling. Studien visar att skriftspråksarbetet i förskoleklass till stora delar liknar skolans sätt att gripa sig an den tidiga läs- och skrivinlärningen. Fokus ligger på arbetet med den grammatiska koden och inlärningen kopplas sällan till barnens tidigare erfarenheter.

Både Fasts (2007) och Skoogs (2012) studier pekar på att förskoleklassens arbete med skriftspråket organiseras som ett separat arbetsspår och integreras således inte med den övriga verksamheten. Skoogs studie visar till exempel att förskollärarna inte vid något tillfälle aktivt förde in skriftspråkliga symboler i den så kallade fria leken. Skoog konstaterar att det är "... långt mellan den barninitierade lek som i verksamheten kallas "fri lek" och den lek som framträder i de lärarledda ”språklekarnas” formaliserade övningar” (Skoog, 2012, s. 208).

När läraren undervisar barnen i förskoleklassen om bokstäver förekommer en betoning på att barnen ska skriva bokstäverna på ett korrekt sätt visar Simeonsdotter Svenssons (2009) avhandling (se även Heikkilä, 2006). Detta medför att barnen behöver sitta stilla för att kunna forma en bokstav. Genom de intervjuer hon har gjort med barnen framkommer att barnen upplever det stillasittande arbetet som problematiskt. Barnen talar till exempel om att benen "vill springa iväg". En slutsats Simeonsdotter Svenssons drar av detta är att förskoleklassen inte har funnit sin egen skolform beträffande att hitta en balans mellan lek och lärande.

Att stimulera barns fonologiska medvetenhet är ett förekommande arbete som sker i förskoleklassen. Detta konstaterar Skolverket (2007) efter att ha gjort en fördjupad granskning av tio grundskolor med avseende på elevernas läs- och skrivutveckling. 


\section{En bild av otydlighet}

Förskoleklassen ${ }^{1}$ innefattas av grundskolans läroplan Lgr11, del 1, vilken handlar om skolans värdegrund och uppdrag. Här framhålls att skolan ska vara öppen för skilda uppfattningar och personliga ställningstaganden samt att undervisningen ska vara saklig och allsidig. Det betonas också att utbildningen ska vara likvärdig, vilket betyder att undervisningen ska anpassas till varje elevs förutsättningar och behov. Undervisningen ska främja elevernas fortsatta lärande och kunskapsutveckling utifrån ”... elevernas bakgrund, tidigare erfarenheter, språk och kunskaper” (Skolverket, 2011, s. 8). En likvärdig utbildning innefattar således inte att undervisningen ska organiseras på samma sätt eller att en skolas resurser ska delas upp lika utan det ska ske med hänsyn till elevernas olika förutsättningar och behov. Det finns olika vägar att nå de fastställda målen. Samtalande, läsande och skrivande framhålls genom att eleverna ska ges ”... rika möjligheter att samtala, läsa och skriva” för att på så sätt "... få tilltro till sin språkliga förmåga” (Skolverket, 2011, s. 9).

Den andra delen i Lgr11 gäller också för förskoleklassen, men i tillämpliga delar. Denna del handlar om utbildningens övergripande mål och riktlinjer där målen fastställer inriktningen på skolans arbete. Avsnittet har rubrikerna normer och värden, kunskaper, elevens ansvar och inflytande, skolan och omvärlden samt bedömning och betyg. Vidare finns också riktlinjer för skola och hem, rektorns ansvar samt övergång och samverkan. I den sistnämnda framkommer att lärarna ska utveckla samarbetet mellan förskoleklass, skola och fritidshem, samt med förskolan i syfte att stödja elevernas utveckling och lärande. Under rubriken kunskaper framhålls skolans ansvar att skapa möjligheter för att varje elev kan använda det svenska språket i tal och skrift på ett rikt och nyanserat sätt, samt kan använda sig av ett kritiskt tänkande och på egen hand uttrycka ståndpunkter baserade på kunskaper och etiska överväganden.

Förskoleklassen omfattas däremot inte av styrdokumentets tredje del som gäller kursplaner och kunskapskrav där ämnenas syfte och centrala innehåll finns preciserat. Några konkretiserade verksamhetsmål finns därmed inte beskrivna för förskoleklassen (Skolverket, 2011). Lärarnas uppdrag blir i och med det att de själva får ta ställning till de olika delarna.

I Skolinspektionens kvalitetsgranskningsrapport (2015:03) där tjugo förskoleklasser granskats med utgångspunkt i den ovannämnda andra delen, visas exempel på hur verksamheten kan ta sig olika uttryck. Rapporten visar att många av lärarna inte utgår från de övergripande målen

1 Lgr11 (2011) är den läroplan som gällde vid den empiriska studiens genomförande. Den 01.07.2016 trädde en reviderad läroplan i kraft, Lgr11 reviderad 2016, där ett avsnitt om förskoleklass har införts med avsikt att förtydliga förskoleklassens uppdrag. 
för kunskaper utan planeringen, genomförandet och uppföljningen av undervisningen styrs istället av lärarnas egna intressen och engagemang.

I vilken studietakt läraren genomför undervisningen kan sägas utgå ifrån en styrgrupp (Dahllöf, 1967; 2002). Styrgruppen är de elever som får frågan från läraren för att hon eller han ska veta om eleverna förstått och kan gå vidare till nästa avsnitt. Det handlar också om att undervisningen utgår från styrgruppen vilket gör att de elever som är i utkanten eller utanför inte möts i sina förmågor. Antingen blir undervisningen för lätt eller för svår för dem och på så sätt uteblir en individanpassad undervisning. Begreppet styrgrupp introducerades i Dahllöfs (1967) arbete om effekten av elevdifferentiering och har vidareutvecklats av Lundgren (1972; 1989). De elever som utgör styrgruppen är inte de som är bäst i klassen och inte heller de som lär sig långsammast. Det är istället den grupp av elever som lär sig något snabbare än de som lär sig långsammast. Styrgruppen fungerar som en kontroll av att de flesta eleverna är med och de bestämmer på så sätt studietakten (Lundgren, 1972; 1989).

Varje elev ska ges möjlighet att nå så långt som möjligt i sin kunskapsutveckling (SFS 2010:800). Läraren anpassar många gånger undervisningen till gruppens medelnivå visar en rapport från Skolverket (2015). Elever som kommit längre i sin kunskapsutveckling får således inte alltid de utmaningar de behöver för att kunna utvecklas så långt som möjligt.

Av SOU (2010:67) framgår att förskoleklassens syfte och verksamhet behöver tydliggöras, vilket också ovanstående beskrivning visar då den ger en förhållandevis olikartad bild av förskoleklassen jämfört med de intentioner som fanns med den. Som ett led i att räta ut otydligheten gav Skolverket i oktober 2014 ut stödmaterialet Förskoleklassen - uppdrag, innehåll och kvalitet. Med grund i skollag, läroplan, forskning och beprövad erfarenhet är stödmaterialet tänkt att bidra till ökad kunskap om och förståelse för förskoleklassens uppdrag, innehåll och kvalitetsutveckling. Med avsikt att förtydliga förskoleklassens och fritidshemmens uppdrag samt övergången mellan förskola, förskoleklass, fritidshem och skola, fick Skolverket i januari 2015 i uppgift att lämna förslag till förändringar i de nuvarande läroplanerna för förskola och skola. Utbildningsdepartementet poängterar dock att de tidigare intentionerna med förskoleklassen ska bestå, det vill säga att förskoleklassen ska vara en bro mellan förskola och skola där syftet är att skapa en trygg övergång mellan verksamheterna. Tanken är att de två utbildningstraditionerna ska möta varandra i förskoleklassen och där gemensamt skapa en pedagogik 
som främjar sexåringarnas utveckling och lärande (Utbildningsdepartementet, 2015)2 ${ }^{2}$.

Ovanstående visar att det finns forskning, rapporter och myndighetstexter om barns och lärares vardag i förskoleklassen. Sammantaget finns emellertid relativt få studier som handlar om förskoleklassen (SOU 2010:67). SOU (2010:67) lyfter fram att det behövs fler studier som undersöker hur lärarnas arbete i förskoleklassen ser ut och vilka erfarenheter barnen har av verksamheten, samt vilket lärande som sker där. Att även mer forskning som inriktar sig mot yngre elevers läs- och skrivundervisning behövs visar en kunskapsöversikt från Vetenskapsrådet (2015). Förskoleklassen har haft en ganska oklar roll som därför behöver förtydligas (Skolverket, 2009; SOU 2010:67). Otydligheten gäller även områden där samtalet, läsandet och skrivandet ingår.

Denna studie har förhoppningar om att bidra med kunskaper om en del av de tomrum som ovan lyfts fram och därför riktas intresset mot vad som sker i förskoleklassens verksamhet då lärares och barns handlingar i samtals- och skriftspråksorienterade lärarledda aktiviteter är i fokus. Som tidigare beskrivits studeras aktiviteterna genom deltagarnas handlingar i tal och skrift, samt genom deras fysiska handlingar såsom gester och ansiktsuttryck. Handlingarna kommer till uttryck genom de sätt som lärare och barn och barn sinsemellan interagerar med varandra, men också genom deras sätt att interagera med den omgivande fysiska miljön. Med ovanstående som utgångspunkt där förskoleklassens roll beskrivs som otydlig när det gäller såväl syfte som innehåll och att mer forskning om förskoleklassen efterfrågas kan studiens syfte och frågor formuleras.

2 Under hösten 2016 publicerades en reviderad upplaga av Lgr11 där förskoleklassen har ett eget avsnitt. Avsnittet förtydligar förskoleklassens syfte och centrala innehåll. Dessutom finns ett förtydligande om övergångar från förskoleklassen till skolan och fritidshemmet. Under hösten publicerades också en reviderad upplaga av förskolans läroplan, Lpfö98. Den läroplanen förtydligades gällande övergångarna från förskola till förskoleklass och fritidshem. 


\section{Studiens syfte och frågeställningar}

Syftet med studien är att bidra med kunskaper om förskoleklassens verksamhet med fokus på lärares och barns handlingar i samtals- och skriftspråksorienterade lärarledda aktiviteter.

Syftet tar utgångspunkt i följande frågeställningar:

- Vad händer i mötet mellan läraren och barnen i dessa aktiviteter?

- Vilka förutsättningar för barns samtalande och skriftspråkande skapas i interaktion mellan läraren och barnen i de lärarledda aktiviteterna? 


\section{Tidigare forskning}

I följande kapitel presenteras tidigare forskning med relevans för studiens fokus, det vill säga mot lärares och barns handlingar i samtals- och skriftspråksorienterade lärarledda aktiviteter. Kapitlet inleds med forskning om interaktion och samtal i klassrummet. Sedan följer en presentation av forskning med fokus på barns tidiga skriftspråkslärande och skriftspråksutveckling.

\section{Klassrumssamtal}

Genom åren har forskning om hur klassrummets interaktion är organiserad och vad det betyder för elevers och lärares deltagande intresserat många forskare. Här har bland annat forskning kring organiseringen av turtagandet i klassrummet och fördelningen av talutrymmet mellan lärare och elever varit i fokus (jfr Einarsson, 2003; Granström, 2005; Mehan, 1979; Sahlström, 2002; Sinclair \& Coulthard, 1975; Wells; 2007).

Det finns en skillnad mellan hur ett klassrumssamtal i helklass och ett vardagssamtal är utformat (Sahlström, 2008). Klassrumssamtal bygger företrädesvis på att interaktionen är organiserad så att när en elev talat klart så talar läraren. I ett vardagssamtal hade det istället kunnat komma in en annan person som talare. Sahlström lyfter fram tre olika lyssnarpositioner som en elev kan inta vid klassrumssamtal i helklass. Den första lyssnarpositionen handlar om att eleven visar i handling att man lyssnar, exempelvis genom att vara vänd mot den talande eller genom att räcka upp handen. I den andra lyssnarpositionen visar eleven inte detta, men pratar heller inte med någon kamrat vid sidan om. I den tredje lyssnarpositionen småpratar en elev med någon eller några av sina kamrater under tiden som läraren talar. När elever deltar i "bänksamtal” vilka Sahlström liknar vid den interaktion som sker vid vardagssamtal, har eleverna avsevärt större inflytande över talsituationen än vad de har vid samtal i helklass.

Inom klassrumsforskningen har samtalsstrukturen IRE/F, Initiering Respons - Evaluering eller Feedback fått stor uppmärksamhet när det handlar om att se mönster för turtagande i klassrummet. IRE/F handlar om att någon, oftast läraren, initierar en handling genom att exempelvis ställa en fråga (I). Responsen (R) som ges av elever bedöms i sin tur av läraren i en evaluerande tredje tur (E) eller så följer läraren upp elevens svar med en ny fråga alternativt utvecklar läraren svaret själv (F) (Mehan, 1979; Sahlström, 2008; Sinclair \& Coulthard, 1975). 
Jämfört med IRE-strukturen kan IRF-strukturen sägas ha ett mer öppnande sätt eftersom läraren följer upp elevens svar istället för att värdera det svar som eleven ger. Sahlström (2008) menar att det finns ett behov av en viss nyansering av IRE-strukturen. Elever är inte så passiva som strukturen vill göra gällande och elever har ett större inflytande över det som sker i klassrummet än vad som framkommer i forskningen om IRE. Elever tar till exempel egna initiativ till samtal genom att de frågar läraren om saker som de undrar över.

När läraren ger respons på en elevs svar så sker det genom olika tekniker. Dessa tekniker kan sägas motsvara den tredje turen i IRE/F-strukturen enligt Mercer (1995). En vanlig teknik är att läraren bekräftar en elevs svar till exempel genom att säga "Det är rätt”. Läraren upprepar också en elevs svar. Upprepningen sker i syfte att uppmärksamma alla elever i klassen på svaret för att det ska kunna vara en hjälp i deras lärande. Genom att omformulera en elevs svar ger läraren en version av det sagda som passar bättre med det som läraren vill lyfta fram. Även att vidareutveckla en elevs svar i sammanhang där eleven uttrycker sig i det närmaste obegripligt framträder som en teknik. Läraren utvecklar då elevens svar och förklarar innebörden för eleverna. När en elev ger ett felaktigt eller opassande svar menar Mercer (1995) att läraren antingen avvisar eller ignorerar svaret.

Lärarens respons på en elevs svar kan även ses genom Hargreaves, McCallum, och Gipps (2000) två kategorier, "evaluting feedback strategies" och "descriptive feedback strategies". Kategorin evaluting feedback strategies innebär att läraren ger respons i form av belöning eller straff, samt uttrycker uppskattning eller missnöje. En belöning kan till exempel vara att en elev får gå fram och skriva på whiteboardtavlan eller att hela klassen applåderar. Ett straff kan exempelvis vara att en elev får flytta ifrån sina kamrater eller får arbeta med en uppgift under lunchtid. Läraren uttrycker uppskattning eller missnöje genom icke verbala handlingar, verbalt och i skrift. Icke verbala handlingar kan till exempel vara att läraren nickar, tar ögonkontakt med barnet, stirrar hårt eller knäpper med fingrarna. Genom att till exempel uttrycka "Bra gjort" eller "Prata inte strunt” visar läraren uppskattning eller missnöje verbalt. På liknande sätt ger också läraren skriven respons till eleverna. I kategorin descriptive feedback strategies fastställer inte bara läraren hur väl eleverna lyckats utan läraren berättar också för eleverna när de har rätt eller fel, beskriver varför ett svar är rätt, berättar för eleverna vad de har uppnått och inte har uppnått, visar på ett bättre sätt att göra något, samt får eleverna att själva föreslå hur de kan göra för att lyckas bättre.

Genom "talk moves” kan ett samtal utvecklas och hålla fokus på det ämne som det är avsett att diskutera (Chapin \& O'Connor, 2007). Talk moves är samtalshandlingar som har potential att höja kvalitén på diskussionen. Chapin och O'Connnor (2007) lyfter fram fem 
samtalshandlingar som läraren kan använda. Den första benämns "revoicing" och kan användas när en elevs svar är oklart. Genom att uttrycka ”Du säger att... Är det rätt? kan en elev få hjälp med att klargöra sin tanke och förbättra sin förståelse. Chapin och O'Connor rekommenderar att läraren försöker repetera så likt det som eleven uttryckt som möjligt för att därefter fråga om det var så eleven menade att säga. Revoicing liknar IRE-strukturen, men skillnaden i den tredje turen innebär att läraren och eleven samarbetar för att utveckla en uppfattning istället för lärarens envägskommunikation (O'Connor \& Michaels, 2007). Den andra samtalshandlingen som lyfts fram av Chapin och O'Connor (2007) är att en elev får repetera det som en annan elev sagt. Syftet med "repeating" kan vara att göra eleverna medvetna om att diskussionen angår alla i klassen. Ett annat syfte kan vara att läraren får möjlighet att lyfta fram ett bidrag, inte för att det var förvirrande utan för att det eleven sa var särskilt betydelsefullt. Ett ytterligare syfte kan vara att genom att repetera en annan elevs uttalande måste eleven reflektera över det som sagts. En tredje samtalshandling "reasoning” är att låta elever ta ställning till ett uttalande genom att fråga om en elev håller med eller inte och också be eleven berätta varför hon eller han gör det ställningstagandet. Genom att läraren frågar om någon har något att tillägga till ett samtal "adding on” kan många elever involveras i samtalet. Denna fjärde samtalshandling möjliggör för elever att noggrant överväga andras idéer, tänka över vad de förstår och formulera det med egna ord. Den femte samtalshandlingen "waiting” och som egentligen inte är någon handling enligt Chapin och O'Connor, innebär att ge eleverna tid att fundera över en fråga innan läraren ber eleverna att svara.

Ett annat mönster som framträder i klassrumsamtal är att uttrycka sig i vi-form. Att prata i vi-form förekommer i samband med att läraren återkopplar till tidigare gemensamma erfarenheter för att presentera en kommande aktivitet (Mercer, 1995). Läraren kan exempelvis säga "Förra veckan lärde vi oss hur man skriver bokstaven S”. Att läraren hjälper eleverna att upptäcka att de har gemensamma erfarenheter är värdefullt. Detta eftersom eleverna får möjlighet att återkoppla till den kunskap som ligger till grund för den aktuella aktiviteten vilket kan vara stöd i deras fortsatta lärande (Mercer, 1995).

I den tidiga klassrumsforskningen har regeln om två-tredjedelar lyfts fram när det gäller fördelningen av talutrymmet mellan lärare och elever vid helklassundervisning. Regeln innebär att läraren i genomsnitt talar två tredjedelar av tiden och den resterande tiden av talutrymmet delar eleverna på (exempelvis Einarsson \& Hultman, 1984; Mehan, 1979; Sinclair \& Coulthard, 1975). Sahlström (2008) menar att senare års forskning pekar på att två-tredjedelsregeln spelat ut sin roll vid beskrivning av hur 
klassrumsinteraktion organiseras. Sahlström framhåller att dagens klassrum i större utsträckning verkar vara organiserade på andra sätt än som helklassundervisning. Han menar även att den tidiga forskningen fokuserat på det officiella och lärarledda samtalet i klassrummet medan den språkliga interaktion som sker mellan eleverna inte beaktats, vilket Sahlström också menar pågår under den tid som helklassundervisningen sker. ”Om man inkluderar dessa samtal i beräkningarna av fördelningen av talutrymmet så blir siffrorna helt annorlunda än i två-tredjedelsregelns formulering, med en betydande övervikt för eleverna” (Sahlström, 2008, s. 27). Granström (2005) som i sin forskning intresserat sig för klassrummets sociala dynamik menar också att interaktion mellan eleverna är mycket mera vanligt än elevernas interaktion med läraren. Sahlström (2008) konstaterar att sättet att se på lärande och klassrumsprocesser har i senare års klassrumsforskning gått från att ha varit lärarorienterad till att även sätta elevernas interaktion med varandra i fokus oberoende av deras relation till av läraren givna uppgifter. Denna vidgning har gett en något annorlunda bild av det som händer i ett klassrum än vad som tidigare framhållits.

Ovanstående avsnitt utgår från forskning om klassrumssamtal i skolan, men liknande processer förekommer i förskoleklassen eftersom det handlar om likartade kontexter.

\section{Det dialogiska klassrummet}

Inom det sociokulturella perspektivet anses såväl interaktion som kommunikation viktiga för att förstå lärande och utveckling på både kollektiv och individuell nivå (Säljö, 2000). Olga Dysthe är en av de forskare som tar sin utgångspunkt i ett sociokulturellt perspektiv och som inspirerats av litteraturteoretikern, språk- och kulturfilosofen Michail Bathkins tankar om dialogens betydelse. Dysthe (1996) beskriver Bakhtins dialogbegrepp som att en människas själva existens i grunden är dialogisk. En person kan inte uppfatta sig som en helhet om denne inte relaterar sig till andra och personen kan bara få kännedom om sig själv genom kommunikation med andra. Språket som dialog är något mycket mera än överföring av budskap från en individ till en annan individ. Förståelse är något som uppstår i dialogen och i samspelet mellan deltagarna. Det budskap som mottagaren tar emot bemöts med någon slags reaktion, till exempel att mottagaren muntligt svarar på ett tidigare yttrande och det är i detta möte som mening och förståelse uppstår. "Understanding comes to fruition only in the response. Understanding and response are dialectically merged and mutually condition each other; one is impossible without the other” (Bakhtin, 1981, s. 282). Dialoger är inte bara något som sker muntligt mellan människor utan är även något man till exempel för med sig 
själv eller i relation till skrivna texter. Att lyssna till "rösten" bakom ett muntligt eller skriftligt yttrande får på så sätt betydelse (Dysthe, 1996).

Dysthe (1996) har i sin forskning från två amerikanska high school klassrum och en norsk gymnasieklass påvisat vikten av det flerstämmiga klassrummet eller det dialogiska klassrummet som Dysthe också uttrycker det. Med det dialogiska klassrummet avser Dysthe ett klassrum där lärarens röst endast är en av alla röster som hörs. I analysen av de dialoger (muntlig och skriftlig kommunikation) som försiggår mellan å ena sidan lärare och elever och å andra sidan mellan eleverna använder sig Dysthe av begreppen "autentiska frågor", "uppföljning" och "positiv bedömning". Autentiska (öppna) frågor är sådana frågor som inte har ett på förhand givet svar och eleverna har då tillfälle att komma med egna yttranden i diskussionen, vilket ger eleverna tillfälle att tänka och reflektera och inte bara minnas och återge. Genom att ställa autentiska frågor får läraren tillfälle att följa upp elevernas svar genom att integrera svaret med den fråga läraren ställer härnäst. Autentiska frågor leder också till "positiv bedömning”, vilket betyder att läraren tar det som eleven uttrycker seriöst och drar nytta av det i den fortsatta undervisningen. Mot det dialogiska klassrummet ställer hon det monologiska klassrummet, vilket kännetecknas av en envägskommunikation där tonvikten ligger på att förmedla och reproducera kunskap. Även om samtal också försiggår i ett monologiskt klassrum så svarar eleverna på lärarens frågor, som är av karaktären "fråga - svar", utifrån vad de tror att läraren förväntar sig. Dysthe menar att ett dialogiskt klassrum är en nödvändighet ”... inte bara för att man ska lära sig ämnen och lära sig tänka självständigt, utan också för att det är en modell för hur människor fungerar i ett demokratiskt samhälle (Dysthe, 1996, s. 249).

Den enskilt viktigaste handlingen som en lärare kan använda för att skifta från ett monologiskt till dialogiskt förhållningssätt är att ställa öppna frågor på vilka det finns flera möjliga svar och sedan uppmuntra eleverna att göra inlägg på kamraternas bidrag. Detta konstaterar Wells och Arauz (2006) efter att ha studerat lärare som under den pågående studien fick lära sig mer om dialogisk interaktion. I början av studien var lärarnas uppföljande inlägg ofta inriktade på vad som var rätt och fel. Efterhand reducerades de inläggen och på så sätt tilläts samtalet ta en mer dialogisk riktning. I början av studien ställde lärarna ofta även frågor som de själva redan visste svaret på, men med större fokus på samtalet och elevernas kunskapskonstruktion deltog lärarna gradvis mera i förhandling om kunskap med eleverna. Wells och Arauz menar att i ett klassrum behöver dialogisk och monologisk hållning sammanflätas och därför är en uppdelning dem emellan av mindre betydelse när läraren ska planera för barns deltagande i samtal. Det som måste avgöra är i vilket syfte en aktivitet sker. De framhåller emellertid att i grunden behöver läraren utgå ifrån ett dialogiskt förhållningssätt. 
Samtal som stödjer barns språkutveckling utmärks av en klassrumsmiljö där samtalet bygger på respekt för varandra (Chapin \& O'Connor, 2007). Ett respektfullt samtal innebär att varje elevs idéer tas på allvar och ingen förlöjligas eller förolämpas. Det innebär även att ingen elev blir ignorerad. Ett antal villkor behöver vara uppfyllda för att respektfulla samtal ska kunna utvecklas i klassrumsmiljön. Det måste finnas (a) tydliga förväntningar på eleverna när det gäller deras roll i klassrumsdiskussionen, (b) klara regler om vad som utgör respekt och respektlöshet, samt att det finns (c) tydliga sanktioner mot respektlöst beteende. Samtal som stödjer barns språkutveckling utmärks även av en klassrumsmiljö, där deltagandet i samtalet innebär att varje barn ges möjligheter att ställa frågor, göra uttalanden och uttrycka sina idéer (Chapin \& O’Connor, 2007).

\section{Faktorer av betydelse för läs- och skrivutvecklingen}

Forskning lyfter fram ett antal faktorer som är av betydelse för ett barns skriftspråkstillägnande. Det finns till exempel ett brett forskningsstöd för att det föreligger ett starkt samband mellan språklig medvetenhet och ett barns läs- och skrivförmåga. Språklig medvetenhet handlar om att ha förmågan att kunna skifta perspektiv från språkets innehåll till dess form, alltså att kunna skifta mellan vad som sägs och hur något sägs. Språklig medvetenhet innefattar olika slags medvetenheter; fonologisk, morfologisk, syntaktisk, semantisk och pragmatisk. Av dessa medvetenheter är det främst det starka samband som föreligger mellan fonologisk, särskilt fonemisk medvetenhet, och barns läs- och skrivutveckling som lyfts fram i forskning (Adams, 1990; Bus \& van Ijzendoorn, 1999; Ehri, Nunes, Willows, Schuster, \& Yaghoub-Zadeh, 2001; Gillon, 2004; Liberg, 2003; Lundberg, Larsman, \& Strid, 2012).

Fonemisk medvetenhet refererar till förmågan att fokusera och manipulera fonemen (språkljuden) i det talade språket, till exempel att kunna lägga till, byta ut eller dra ifrån ett fonem i ett ord. Fonemisk medvetenhet ingår i det vidare begreppet fonologisk medvetenhet. Fonologisk medvetenhet innefattar språkets ljudmässiga uppbyggnad där även rim och stavelser ingår (Ehri et al., 2001; Liberg 2003). Den fonologiska medvetenheten kan därmed sägas ha två dimensioner, en ytlig och en djup. Den ytliga dimensionen innebär att ha medvetenhet om de stora enheterna i språket (rim och stavelser) medan djup känslighet refererar till fonemen. Den ytliga dimensionen anses vara den som uppnås först, vilket ofta sker i förskoleåldern medan en djup dimension utvecklas i samband med den tidiga läsningen (Goswami \& Bryant, 1990). 
Den optimala tidslängden för hur länge arbetet med fonemisk medvetenhet bör pågå är mellan 5 och 18 timmar, max 30 minuter per gång. Tidslängden ska ses som en riktlinje då vissa barn kan komma att behöva mer tid för träning än så (Ehri et al., 2001). Arbetet med fonemisk medvetenhet behöver ske genom lek med språket och samtal kring det man läser och skriver om (Liberg, 2007b).

Ett klassiskt projekt i detta sammanhang skedde på Bornholm mellan åren 1985-1990. Projektet utgick ifrån barn i bornehaveklasser som dagligen uppmärksammades på språkljuden genom strukturerade språklekar. Barnen från Bornholm som fick leka med språkljuden jämfördes kontinuerligt med grupper av barn på Jylland som inte ingick i något språkträningsprogram. Resultatet visade att träning av språkljud gav effekt och barnen på Bornholm blev senare bättre på att läsa och stava jämfört med barnen på Jylland. Störst nytta av träningen hade speciellt de språksvaga barnen. Projektet visade att det går att stimulera barns fonologiska medvetenhet och det ger effekt på barns läsning och skrivning (Lundberg, Frost, \& Petersen, 1988).

Det finns forskning som visar att språkljud som sammankopplas med bokstäver (grafem) bidrar mer effektivt till barns läsutveckling kontra övningar som endast fokuserar på medvetenhet om språkljud (Bradley \& Bryant, 1983; Bus \& van Ijzendoorn, 1999; Hatcher, Hulme, \& Ellis, 1994; Liberg, 2003; National Reading Panel, 2000). En viktig del i läslärandet är att barnet kan koppla samman språkljud och bokstav. Barnet behöver ha förståelse för att de talade orden kan delas upp i språkljud, de behöver också kunna identifiera språkljuden och koppla dessa till de korrekta bokstäverna. Det är när barnet förstår sambandet emellan dem som den alfabetiska koden knäcks. Enligt Scarborough (1998) är bokstavskunskap en central faktor för den första läsinlärningen. Barn som kan många bokstäver i förskoleåldern klarar i regel den inledande läsningen bra.

I Oslo genomfördes mellan åren 1986-1989 ett projekt där syftet var att se hur tal- och skriftspråket kan stimuleras genom lek för barn i åldern kring sex år. Grunden för projektet var att barns lärande av skriftspråket utvecklas i en miljö som är naturlig för barnen. Lärarens uppgift var att inspirera och skapa ramar så att barnen på eget initiativ och i egen takt fick lust att utforska och leka sig in i skriftspråket. Olika skriftspråksstimulerande aktiviteter genomfördes exempelvis att uppmärksamma begynnelseljud i ord. Lekskrivning och lekläsning uppmuntrades från början. Resultatet visade att av de 50 barn som deltog i studien knäckte 43 av dem den alfabetiska koden innan de gick vidare till skolan. Vikten av att den fonologiska träningen behöver ske tillsammans med övningar i att läsa och skriva lyftes fram. Det framkom också att barnen upplevde att det var de själva som lärt sig läsa och skriva. Resultatet visade även att periodvis var 
vissa barn i behov av en mer systematisk undervisning av bokstävernas namn och språkljud (Eriksen Hagtvet \& Pálsdóttir, 1993).

Forskning om läs- och skrivsvårigheter har visat att ett barn som riskerar att få svårigheter i sin läsning och skrivning tidigt behöver en ordnad och strukturerad undervisning i den alfabetiska kodens principer (Adams, 1990; Moats, 2009; Myrberg, 2001) och med det blir det därför också viktigt att som lärare vara medveten om den enskilda elevens aktuella kunskapsnivå (Hattie, 2009).

Förutom att framför allt fonemisk medvetenhet och bokstavskunskap har stor relevans för ett barns läs- och skrivutveckling finns det också andra faktorer som är av betydelse. Ordförrådets storlek är ett exempel på en sådan faktor som påverkar läsförståelsen (Braze, Taber, Shankweiler, \& Mencl, 2007; Elleman, Lindo, Morphy, \& Compton, 2009; Elwér, 2014; Schoonen \& Verhallen, 2008; Stanovich, 2000; Snow \& Juel, 2007). Scarborough (1998) redogör i en metaanlys för ett antal språkliga färdigheter i förskoleåldern som förutsäger läsutvecklingen i de tidiga skolåren. Här lyfts barns aktiva ordförråd fram, men även till viss del det passiva. Ordförrådet kan utökas med hjälp av flera olika undervisningsmetoder men det går inte att avgöra vilken ordkunskapsstrategi som bäst främjar förståelsen. Detta konstaterar Vetenskapsrådet (2015) efter att ha kartlagt och sammanställt ett antal internationella och nationella forskningsresultat med relevans för skola och förskola. Att nya ord behöver förklaras utifrån det sammanhang de ingår i visas i en studie gjord av Weizman och Snow (2001). Antingen genom direkt undervisning av ordet, till exempel förklaring av ordet muntligt, förklaring genom att peka på en bild eller med hjälp av gester eller indirekt undervisning där samtalskontexten ger betydelsen av ordet. Även Mc Cormack och Lee Pasquarelli (2010) menar att förklaringar av nya ord behöver ske utifrån det sammanhang de ingår i. När nya ord förklaras behöver orden sättas samman med barnens tidigare erfarenheter. Att upprepa de nya orden i olika sammanhang, samt ge möjligheter för barnen att använda de nya orden på ett för dem meningsfullt sätt lyfts också fram som fördelaktigt för att utöka barns ordförråd (Cormack \& Lee Pasquarelli, 2010).

En annan faktor som lyfts fram i forskning och som har betydelse för ett barns läs- och skrivutveckling är medvetenhet om morfem (minsta betydelsebärande enhet i ord). Medvetenhet om morfem har tydliga och positiva effekter på barns ordavkodning och stavning (Kirk \& Gillon, 2009; Wolter, Wood, \& D’zatko, 2009). Att stimulera barns morfologiska medvetenhet kan exempelvis göras genom att analysera sammansatta ord eller genom att identifiera, ta bort och lägga till stavelser i ord (Vetenskapsrådet, 2015). I en studie gjord av Wolter et al., (2009) framkommer att barn som gick i första klass redan var morfologiskt 
medvetna och att de använde sin morfologiska kunskap när de stavade ord. Detta betyder att den morfologiska kunskapen kan stimuleras tidigare hos barn än i första klass. Att i tidig ålder stimulera barns kunskap om ords struktur är sannolikt att ge dem en strategi som de kan använda för att stava, identifiera, avkoda och förstå morfologiskt komplexa ord (Wolter et al., 2009).

För att förstå innehållet i en text är syntaktisk medvetenhet av betydelse (Vellutino, 2003). Syntaktisk medvetenhet underlättar övervakningen av förståelsen i termer av att barnet kan upptäcka om det finns något grammatiskt fel i en mening.

Andra faktorer som har betydelse för ett barns läs- och skrivutveckling är förmågan att återge meningar och historier, samt förmågan att vara en aktiv samtalspartner (Liberg, 2007b; Snow, Burns, \& Griffin, 1998). Barns uppväxtmiljö har stor betydelse för det språkliga samspelet. Forskning visar att det är gynnsamt för barns kognitiva och språkliga utveckling att växa upp i en miljö med god tillgång till läs- och skrivmaterial och med läs- och skrivförebilder i form av vuxna som interagerar språkligt med dem. Därmed ges barnen möjlighet att delta i olika läs- och skrivaktiviteter, där språkliga stödstrukturer skapas. Alla barn ges inte dessa förutsättningar, vilket betyder att barn kommer till skolan och förskoleklassen med olika erfarenheter av att delta i samtal, läsande och skrivande (Liberg, 2007b; Myrberg, 2001).

\section{Att läsa och skriva}

Den forskningsinriktning som genom åren dominerat synen på hur barn utvecklar läs- och skrivförmågan finns inom det perspektiv som brukar kallas för det intraindividuella perspektivet (Liberg, 2003). Inom perspektivet har till exempel forskning om hur barn utvecklar sin fonologiska medvetenhet och vilken betydelse den har för barns avkodningsförmåga varit framträdande. Under den senare delen av 1900talet växte enligt Liberg (2003) en ny forskningsinriktning fram där forskare betonade det sociala sammanhanget för barns tidiga läsande och skrivande. Forskningsinriktningen benämndes "early literacy". Denna forskningsinriktning brukar sägas ha ett interindividuellt perspektiv på läsoch skrivförmågan där utvecklingen av förmågan antas betyda att individen blir mer och mer avancerad i att delta och vara medaktör i ett skriftspråkligt meningsskapande. Här har till exempel forskning om hur barns läs- och skrivförmåga utvecklas i förskoleåldern och den läs- och skrivmiljö som de är en del av varit framträdande. En annan aspekt som också varit framträdande har handlat om de samtal som barnen för med andra som de 
läser och skriver tillsammans med (Liberg, 2003).”Early literacy”/litercy3 forskningen innebär ett vidgat sätt att se på läsning och skrivning. Skriftspråklighet förknippas inom detta perspektiv dels med människors sociokulturella förutsättningar, dels med de funktioner som användning av skrift kan ha i olika situationer och för olika människor (Liberg, 2003; Liberg, Folkeryd Wiksten, \& Af Geijerstam, 2012). De flesta forskare som rör sig i fältet kring "early literacy” och "språklig medvetenhet” har med åren skapat en samstämmighet på barns tidiga skriftspråkstillägnande (Liberg, 2007b). "Det handlar inte om ett antingen eller, utan om ett både och" (Liberg, 2007b, s. 35).

Läsning innefattar både avkodning och förståelseprocesser. Ett vanligt sätt att definiera detta är utifrån modellen The simple view of reading, vilken uttrycks som Läsning = Avkodning x Förståelse (Gough \& Tunmer, 1986). Forskare som tar sin utgångspunkt i denna formel har den enskilde individen och hans eller hennes utveckling av de två komponenterna i fokus (Adams, 1990; Hoien \& Lundberg, 1999).

Avkodning handlar om att identifiera bokstäverna, omkoda dem till ljud och foga samman ljuden till ord. Avkodningen brukar beskrivas som den tekniska sidan av läsningen. Det gäller för läsaren att utnyttja den alfabetiska koden för att lyckas avläsa vad som står skrivet. Avkodningen byggs upp över tid och allteftersom läsaren stöter på ett särskilt ord stärks minnesbilden av det och så småningom kan ordet kännas igen snabbt och säkert. Avkodningen är den komponent som behöver bli automatiserad (Adams, 1990; Hoien \& Lundberg, 1999). Förståelseprocessen handlar om att förstå innehållet $\mathrm{i}$ det man läser och om att kunna koppla till egna erfarenheter, kunna dra slutsatser, göra värderingar av det lästa och så vidare (Hoien \& Lundberg, 1999). Med åren har också en del forskare utökat läsmodellen med ytterligare en komponent, motivation (Dalby, Elbro, Jansen, \& Krogh, 1992).

Skrivning innefattar liknande komponenter som läsningen. Skrivning kan definieras med modellen Skrivning $=$ Inkodning $\mathrm{x}$ Budskapsförmedling. Inkodning handlar om att omkoda språkljud till bokstäver, omskapa en intention att förmedla något till ett budskap och att integrera bokstäver, ord och satser till det tänkta budskapet (Eriksen Hagtvet, 2009).

Barns tidiga skrivande har sitt ursprung i deras ritande. Barnen avbildar till exempel saker som finns i deras närhet eller upplevelser som de har varit med om. När barn ritar, till exempel en sol, fungerar tecknandet som skriftspråket enligt Vygotskij (1934/2010). De bokstäver som barnet skriver i ett första skede får då samma funktion som tecknandet. Det här

3 För vidare läsning om begreppen hänvisas till kapitlet om teoretiska utgångspunkter. 
betyder att när barnet skriver en speciell bokstav så symboliserar den ett särskilt objekt för barnet. När ett barn förstår att det talade språket kan skrivas ned och att det består av ljud som motsvaras av bokstäver har skriftspråksutvecklingen gått från avbildningar av objekt till avbildning av talspråket.

Liberg (1990), som i sin avhandling undersökt elva förskolebarns vägar till skriftspråket, menar att det tidiga utforskandet av skriftspråket sker med hjälp av det hon kallar för gemensamt effektivt läsande och skrivande. Barnen deltar i de läs- och skrivaktiviteter som initieras av vuxna, vilket väcker barnens intresse och kunskap om vad läsande och skrivande innebär. Vid den nästkommande typen av läsning och skrivning som benämns begränsat effektivt läsande och skrivande går barnet mer självmant på upptäcktsfärd i skriftspråket. Många barn tar då också spontant in läsandet och skrivandet i leken och prövar på så sätt själva på att läsa och skriva. I den här typen av läsning och skrivning ingår det som Liberg (1990; 2006: 2007b) kallar för preläsande och preskrivande. Barnet beter sig då som en utvecklad läsare och skrivare gör, men skriver till exempel egna påhittade krumelurer istället för konventionella bokstäver. Ett situationsläsande och situationsskrivande där ett slags kopierande sker, samt ett läsande och skrivande utifrån helord innefattas också i ett begränsat effektivt läsande och skrivande. I ett grammatiskt läsande och skrivande förstår barnet sambandet mellan språkljud och bokstav. Målet är att nå ett utvecklat effektivt läsande och skrivande, det vill säga ett konventionellt läsande och skrivande, men för att lyckas med detta behöver barnet under hela sin skriftspråksutveckling ha den vuxne som stödstruktur (Liberg, 1990; 2006: 2007b).

Skoog (2012) har undersökt hur det tidiga skriftspråkslärandet konstrueras i förskoleklass och årskurs 1 . Av studien framkommer att det till viss del lämnas utrymme för barnen att skriva i sammanhang som kan beskrivas som funktionella, det vill säga där det fyller en reell funktion för barnen. Skoog lyfter bland annat fram ett exempel där barnen i en av undersökningens förskoleklasser skriver egna påhittade meningar till en given bild, vilket lämnar ett visst utrymme för barnen att själva skriva ett textinnehåll samtidigt som de också utforskar relationen mellan ljud och bokstav. Men eftersom eleverna sammantaget sällan uppmuntras att skriva fritt och självständigt konstaterar Skoog att "... den potential som ett utforskande skrivande kan erbjuda för att stödja elevernas tänkande och lärande” (Skoog, 2012, s. 204) inte utnyttjas i klassrummet.

De lärare som ingår i Fasts (2007) studie förhåller sig olika till barnens skrivande. Några av lärarna låter barnen skriva fritt relativt tidigt i förskoleklassen. Barnen får exempelvis skriva dagböcker och egna böcker om olika ämnen. Andra lärare låter inte alls barnen skriva fritt utan de får framför allt skriva av ord från whiteboardtavlan. 
Hur 41 barn som går i första klass talar om sitt skrivlärande och vilken strategi barnen använder sig av i sitt skrivande har undersökts i en studie av Gustafsson och Mellgren (2005). Resultatet visar bland annat att det finns barn som upplever läs- och skrivundervisningen som otydlig. Barn som uttrycker svårigheter med sitt skrivlärande använder sig av minneslappar där bokstäverna och orden finns nedtecknade. Flera barn uttrycker oro över att de inte kan tillräckligt mycket. Barn som läser och skriver uttrycker någon form av emotionellt missnöje eller upplever krav på att prestera, men det finns också barn som uttrycker att de saknar utmaningar. Resultatet visar även att barn tar egna initiativ för att komma vidare i sitt skrivlärande vilket inte är givet att läraren är införstådd med att barnet gör.

Traditionellt har läs- och skrivundervisningen gått från att lära barn att läsa till att lära dem skriva. På senare år har de emellertid setts som kompletterande processer. En del forskare har dessutom argumenterat för att skrivningen ska stå i centrum istället för läsningen när det formella skriftspråkslärandet startar. Vid skrivning utgår barnet från ord som de själva valt, till skillnad från läsningen där någon annan valt orden. Barnet deltar därför mer aktivt i processen när de skriver än när de läser (Björk \& Liberg, 2004; Liberg, 1990). När många barn själva väljer så närmar de sig skriftspråket genom skrivandet (Björk \& Liberg, 2004; Liberg, 2006).

\section{En balanserad läs- och skrivundervisning}

Diskussionen bland forskare och lärare har genom åren internationellt och nationellt stundtals varit hätsk då det gäller vilken metod som är mest lämpad att utgå ifrån då barn ska lära sig läsa. Två läsinriktningar, ljudmetoden (phonics) och helordsmetoden (whole language), har varit framträdande (Liberg, 2003; Snow \& Juel, 2007). De två inriktningarna har olika synsätt på den tidiga läsundervisningen. Den förstnämnda utgår ifrån delarna i språket, fonemen och bokstäverna. Dessa ljudas samman för att få ett läsflyt så att en förståelse för innehållet kan uppnås, en så kallad bottomup- process. Den senare utgår ifrån helheten och man utnyttjar hela texter, fraser och ord för att förstå delarna, en så kallad top-down-process (Liberg, 2003; Snow \& Juel, 2007).

De olika synsätten på läs- och skrivinlärning har beskrivits i termer av ett "reading war". I USA var "the reading war" mest aktuellt under 1950och 60-talet (Liberg, 2003; Snow \& Juel, 2007). I Sverige förekom liknande

diskussioner under 1970-talet (Hjäme, 1999). Gradvis har meningsskiljaktigheterna om vad som är god läsundervisning tonats ner efter att bland annat Snow, Burns, och Griffin (1998) publicerade National Research Council's (NRC) konsensusrapport. I rapporten förespråkas en balanserad syn på läsandet där ståndpunkter från båda inriktningarna finns 
representerade. Rapporten lyfter fram betydelsen av att barn behöver få en klar uppfattning om kopplingen mellan tal- och skriftspråk, men också att läsning och skrivning behöver ingå i meningsfulla sammanhang där barnen får möjlighet att utveckla strategier för att förstå en text. I rapporten framkommer vikten av att arbeta med fonologisk medvetenhet och att utveckla barns ordförråd i förskolan då det är av betydelse för barns senare läsförmåga. Vellutino och Scanlon (1986) har i sin forskning visat att barn får en bättre läsutveckling när både ljudmetod och helordsmetod tillämpas än när bara en av läsinriktningarna används. Detta kommer också Myrberg (2001) fram till i den svenska konsensusrapporten. Enligt Liberg (2003) förordas numera "så kallade balanserade program inom vilka ljudmetod och helordsmetod kombineras" (Liberg, 2003, s. 209).

Vidare menar Liberg (2008) att det i varje undervisningssammanhang finns minst tre olika sätt att arbeta med metoder. Den första undervisningsformen kännetecknas av att man arbetar fristående med det som ska läras utan att sätta in det i ett sammanhang där det fyller en funktion. Detta är ett exempel på en starkt formaliserad undervisning. Den andra undervisningsformen utmärks av att man sätter in det som ska läras i det sammanhang där det fyller en funktion, men eleverna görs inte uppmärksammade på sammanhanget utan de får själva försöka upptäckta det. Detta är ett exempel på en starkt funktionaliserad undervisning. Liberg förordar en tredje typ där det råder en balans mellan dessa båda undervisningsformer. Det som ska läras är anpassat till ett sammanhang där det fyller en funktion, men det studeras även separat och strukturerat. Ett undervisningssammanhang där det råder balans mellan en formaliserad och funktionaliserad undervisning är den där språkets form, innehåll och funktion är i samspel med varandra.

\section{Högläsning och samtal om texter}

Det finns ett starkt forskningsstöd för att högläsning och samtal om texter har en central roll för ett barns språkutveckling (Adams, 1990; Baker, Santoro, Chard, Fien, Park, \& Otterstedt, 2013; Liberg, 2003; 2007b; Leppänen, Aunola, \& Nurmi, 2005; Snow, Burns, \& Griffin, 1998). I sammanhang där högläsning och samtal om texter förs förekommer ofta begreppet textrörlighet. Att vara textrörlig innebär enligt Liberg (1990; 2007b) att kunna röra sig i en text på olika sätt och genom sitt sätt att samtala, läsa eller skriva om innehållet i texten så visar man sin textrörlighet. Liberg framhäver betydelsen av textrörlighet när hon ser på ett barns förmåga att förstå texter och menar att grunderna för textrörlighet börjar innan barn läser och skriver själva. Libergs syn på begreppet textrörlighet är inspirerat av Langers (1995) sätt att se på meningsskapande 
när det gäller läsning av skönlitteratur. Langer menar att meningsskapande äger rum genom att läsaren bygger föreställningsvärldar (mentala textvärldar). Langer urskiljer fyra faser som läsaren kan växla mellan under samma läsning. Den första fasen innebär att läsaren går in i en föreställningsvärld utifrån de kunskaper och erfarenheter som läsaren har samt utifrån de ytliga drag som texten har. Läsaren bekantar sig med texten. I den andra fasen är läsaren inne i och rör sig genom en föreställningsvärld. Läsaren begrundar då känslor, motiv och relationer som finns i textens handling. Den tredje fasen handlar om att stiga ur texten och jämföra det lästa med sina tidigare erfarenheter. Den sista fasen innefattar att läsaren håller texten ifrån sig och reflekterar över den. Texten begrundas och jämförs med andra liknande texter, samt granskas kritiskt (Langer, 1995; Liberg, 2007b).

Liberg (2014) har inspirerats av de olika faser som Langer (1995) menar att en läsare kan röra sig i en text. Ett sätt handlar om att röra sig i texter intratextuellt. Rörelserna leder till att individen rör sig inom texten på ett horisontellt eller vertikalt sätt. Genom horisontella rörelser rör sig individen på textens yta exempelvis för att hitta enskilda detaljer i texten. Genom vertikala rörelser rör sig individen för att komma på djupet av texten och exempelvis se samband mellan olika inslag och dra enkla slutsatser. Ett annat sätt handlar om att röra sig i texter intertextuellt. Rörelserna leder till att individen rör sig ut från texten och in i andra texter och andra sammanhang. De intertextuella rörelserna medverkar exempelvis till att knyta an till egna erfarenheter, knyta an till helt andra texter eller upplevelser eller distansera sig från det skrivna eller sagda för en mer kritisk granskning. Olika typer av textrörlighet krävs i olika sammanhang och därför finns det inte ett sätt som är bättre eller sämre än något annat (Liberg, 2014).

Det sätt som samtal om texter förs på har betydelse för ett barns läs- och skrivutveckling. I en longitudinell studie visar De Temple och Snow (2001) att barn vars mödrar högläser böcker och samtidigt samtalar med ett mer dekontextualiserat ${ }^{4}$ språk visar en gynnsammare literacyutveckling jämfört med de mödrar som använder ett mer kontextualiserat ${ }^{5}$ språk med sina barn. Studien visar också att vilket språk mödrarna använder hänger samman med deras socioekonomiska status. Generellt sett är det mödrar med låg utbildning och med en högre risk för social utsatthet som använder sig av ett mer kontextualiserat språk. Barn som deltagit i kontextualiserade samtal har enligt Liberg (2003; 2007b) inte lika god läs- och skrivutvecklingsprognos som barn som deltagit i dekontextualiserade samtal.

\footnotetext{
4 Samtal som syftar till att distansera sig från textens betydelse.

5 Samtal som syftar till redogörelse för vad som precis står i texten.
} 
Jönsson (2007) beskriver i sin avhandling elevers läsning av skönlitteratur och det litteraturarbete som finns runt läsning i en klass där hon själv verkar som lärare. Studien har sitt fokus mot årskurs F-3. Resultatet visar att under litteraturarbetet använder sig läraren och eleverna kontinuerligt av strategier såsom att förutspå, ställa frågor, reda ut otydligheter och summera i sitt förståelsearbete. Intervjuer med eleverna visar att den gemensamma läsningen får olika betydelser för olika elever. En elev ställer sig till exempel positiv till de högläsningsböcker som läraren läser och vill själv läsa samma böcker som läraren läst, medan en annan elev som först hade en skeptisk hållning till läsningen genom samtalen drogs med in i läsningen under tiden som arbetet varade. Studien visar att eleverna arbetar aktivt med att förstå och skapa mening under läsningen, det vill säga att de bygger föreställningsvärldar.

Cochran-Smith (1984) undersökte i en studie hur lärare och barn i åldrarna 3-5 år samspelar i ett antal högläsningssituationer. Av studien framgår att läraren samtalar med barnen i samband med att hon läser texten högt. Genom att ställa frågor till barnen knyter läraren det lästa till barnens egna erfarenheter (life-to-text strategies). Läraren kopplar också böckerna till det arbete som pågår på förskolan (text-to-life strategies). Läsning och skrivning är så mycket mer än bara avkodning och kodning då dessa färdigheter även behöver sättas samman med skriftens funktion fastslår Cochran-Smith. "Without knowledge of how to use print, the abilities to encode and decode print are meaningless" (Cochran-Smith, 1984, s. 258).

Att den högläsning som eleverna möter utgör ett fristående inslag i undervisningen framkommer i Skoogs (2012) studie. De böcker som lärarna väljer att läsa har inte någon innehållskoppling till det som eleverna för övrigt sysslar med. De samtal som förs mellan lärarna och eleverna rör sig mestadels på textens yta och på så sätt uteblir de mer fördjupade samtalen. Skoog konstaterar att det finns en didaktisk utmaning i hur lärare, som arbetar mot de yngre skolåldrarna, ska ge elever möjlighet att "... läsa, skriva och arbeta med olika typer av texter för att gradvis utveckla sin förmåga att se innebörden i och förhålla sig kritiskt till de texter de möter” (Skoog, 2012, s. 207).

Betydelsen av att barn ges stöd $i$ att utveckla förståelsestrategier förordas av flera forskare (exempelvis Mohammad Reza \& Hairul Nizam, 2012; Pilonieta \& Medina, 2009; Pressley, 2006; Spörer, Brunstein, \& Kieschke, 2008). Palincsar och Brown (1984) är ett par av de forskare som menar att stöttningen av den utvecklingen kan ske genom textsamtal. De har i sin forskning urskilt fyra olika förståelsestrategier som goda läsare använder för att förstå en text. Goda läsare (a) förutspår handlingen, (b) ställer egna frågor om texten, (c) reder ut otydligheter och (d) sammanfattar texten. När läraren introducerar strategierna för eleverna gör hon det genom att vara modell där läraren visar strategierna högt. Allteftersom kan eleverna själva 
ta över och de får pröva att agera så som läraren gör. Genom detta sätt att arbeta blir undervisningen reciprok. Målet med undervisningen är att uppmuntra eleverna att delta aktivt i att gemensamt skapa förståelse för en text och att eleverna ska få ett metaperspektiv på sitt eget lärande (Palincsar \& Brown, 1984). När arbetet med högläsning och de fyra strategierna sker med barn i yngre åldrar kan strategierna göras mer elevvänliga genom att exempelvis använda dockor eller andra redskap som symboliserar de olika strategierna (Myers, 2005; Oczkus, 2003).

Att ställa frågor till texten och att sammanfatta texten lyfter också National Reading Panel (2000) fram som betydelsefulla strategier för utveckling av läsförståelse. Andra strategier som framhävs är samarbete mellan elever och att övervaka förståelsen, det vill säga att vara medveten om när man inte förstår och att då kunna sätta in lämplig åtgärd. Även att koppla till egna erfarenheter är en strategi som lyfts fram för utveckling av elevers läsförståelse (Roberts, 2013). Att sammankoppla flera av förståelsestrategierna på en och samma text verkar också ge effekt (Duke \& Pearson, 2002; National Reading Panel, 2000; Palinscar \& Brown, 1984).

Myers (2005) beskriver i en studie sitt lärararbete med en grupp femåringar där högläsning och reciprok undervisning förekom under tre månader. Hon intervjuade barnen före och efter projektet, samt gjorde videoinspelningar under projektets gång för att se vilken förändring arbetet haft. Resultatet visar att barnen självmant och aktivt började använda strategierna och inte bara på högläsningstexter utan även i andra sammanhang. Barnens intresse för högläsning ökade. Barnen utvecklade sin förmåga att vara samtalsledare och de utvecklade även en medvetenhet om sitt eget lärande. Slutsatsen Myers drar är att "Kindergarten students are not too young to learn strategies that will help them assume responsibility for their own learning and to lead discussion groups for their peers" (Myers, 2005, s. 323).

Att som lärare vara flexibel när det gäller arbetssätt kring texter har samtidigt visat sig vara betydelsefullt i arbetet med att utveckla barns läsförståelse. McKeown, Beck, och Blake (2009) har i en studie följt lärare och elever i några klasser i årskurs fem och två år framöver. Några av klasserna arbetade med att förstå berättelsen utifrån ett fokus på läsförståelsestrategier medan andra klasser arbetade med texten där ett fokus låg på att förstå innehållet och helheten i berättelsen. Studien visar att ett ständigt pågående fokus på läsförståelsestrategier under läsningen ger mindre effekt på elevernas läsförståelse än när ett fokus ligger på att diskutera helheten i berättelsen med eleverna. Forskarna menar att det behöver råda en balans mellan de två olika sätten att arbeta med läsförståelse i klassrummet för att få den bästa effekten. 


\section{Sammanfattning}

I detta kapitel har forskning med relevans för att förstå lärares och barns handlingar i samtals- och skriftspråksorienterade lärarledda aktiviteter redovisats. I forskningsgenomgången framkommer att organiseringen av klassrummets interaktion har betydelse för ett barns deltagande i samtal. I klassrumssamtal är exempelvis IRE/F strukturen av betydelse där framför allt lärarens tredje tur får relevans för barnets deltagande i samtalet. Forskningsgenomgången visar på betydelsen av ett dialogiskt klassrum vilket innebär att både lärarens och barnens röster blir hörda. Vidare pekar forskningsgenomgången på ett antal faktorer som är av betydelse för ett barns skriftspråkstillägnande, till exempel fonemisk medvetenhet och bokstavskunskap. Läsningens och skrivningens komponenter och olika forskningsinriktningars syn på dessa har belysts. Forskningsgenomgången visar att det finns två olika synsätt på den tidiga läsundervisningen. På senare år har de två synsätten emellertid kommit att ses som varandra kompletterande. Att högläsa och samtala om texter visar sig ha betydelse för barns språkutveckling. I dessa samtal behöver läraren bland annat ge barnen stöd i att utveckla strategier för att förstå texter. 


\section{Teoretiska utgångspunkter}

I detta kapitel ges en presentation av studiens teoretiska utgångspunkter. Kapitlet inleds med en beskrivning av det sociokulturella perspektivets syn på lärande, utveckling och språk och några för studien centrala begrepp definieras. Då studien riktar sitt fokus mot lärares och barns handlingar i samtals- och skriftspråksorienterade lärarledda aktiviteter ges även en presentation av den sociokulturellt inriktade literacyforskningens centrala utgångspunkter.

\section{En sociokulturell syn på lärande och utveckling}

Ur ett sociokulturellt synsätt är lärande en aspekt av alla mänskliga handlingar och kan därför inte ses som något som enbart sker i skolan. Lärande handlar om hur individen tar till sig och gör kunskapen till sin egen i sin egen takt eller med en sociokulturell terminologi, approprierar de kunskaper och färdigheter som denne möter (Säljö, 2000; 2013). Förståelse av lärande innebär att kunskaper och lärande anses som situerade, alltså något som konstrueras i den sociala praktiken (Säljö, 2000; 2003). Interaktionen mellan individen och kollektivet är i fokus och de kunskaper och erfarenheter man tillägnar sig anses tidigare utvecklats i samhället och mellan människor. Lärandet och tänkandet ska emellertid inte ses som något som står still utan istället något som utvecklas genom hela livet. Genom att till exempel resonera med andra kommer nya insikter som individen handlar efter. Genom att se på hur individer handlar vid olika slags aktiviteter och vilka erfarenheter de då gör, det vill säga deras sätt att skapa mening, blir en individs allmänna egenskaper mindre viktiga när det gäller att försöka förstå och förklara lärande. Att delta i aktiviteter blir på så sätt en nödvändighet för människors lärande och utveckling (Säljö, 2013).

Begreppet appropiera är enligt Björklund (2008) hämtat från Wertsch där Wertsch och Rogoff i sin tur hämtat begreppet ifrån Batkin (1981). Rogoff (1990) har sedermera utvecklat begreppet till deltagande appropiering. Detta för att framhålla deltagandets betydelse i lärandet. Internalisera är däremot det begrepp som Vygotskij (1978; 1934/2010) använder. Vygotskij menar att mentala funktioner först finns mellan individer (interpersonellt) och därpå inom individen (intrapersonellt). Detta betyder till exempel att språket först utvecklas i ett socialt sammanhang och därefter införlivas och sedan kan användas av individen för att tänka (Vygotskij, 1978; 1934/2010). Säljö (2000) och Rogoff (1990) menar att 
detta synsätt, att gå mellan en gräns av yttre och inre, kan tolkas som att det finns en åtskillnad mellan kroppen och tanken, en åtskillnad mellan intellektet och fysiska och sociala handlingar, vilket är något som det sociokulturella perspektivet vill komma ifrån. Säljö menar att det i internaliseringsbegreppets innebörd finns en tanke om att ersätta kunskaper, färdigheter och ståndpunkter med andra. Gamla kunskaper får på så sätt bereda plats för nya. Sammantaget menar Säljö att man hellre bör se på lärande utifrån ett situerat sätt och på så sätt försöka förstå vad som händer när människor tillägnar sig kunskaper. Säljö konstaterar att

Lärandets problem handlar om vilka erfarenheter människor gör i en situation och vilka innebörder, tolkningar och handlingsmönster man tar med sig till andra kontexter senare i livet. Lärande handlar om att bli delaktig i kunskaper och färdigheter och att förmå bruka dem på ett produktivt sätt inom ramen för nya sociala praktiker och verksamhetssystem (Säljö, 2000, s. 151).

Det görs heller ingen distinkt gräns mellan tanke och tal. Det handlar om ett aktivt deltagande där människor ger och tar i samverkan med varandra (Säljö, 2000; 2013). Med ett sociokulturellt perspektiv på lärande suddas gränsen mellan något yttre och något inre ut (Säljö, 2000).

\section{Språkets centrala roll}

Språket har ett antal olika funktioner. Det har bland annat en utpekande funktion som att människor kan benämna saker i sin omgivning eller använda gester för att peka ut dem. Språket har även en semiotisk (semantisk) funktion vilket innefattar förhållandet mellan det språkliga uttrycket och den erfarenhet det refererar till. Språket har dessutom en retorisk funktion som handlar om hur människor använder språket i olika sammanhang (Säljö, 2000; Vygotskij, 1934/2010).

Kommunikation med språket som redskap intar en särställning vid tillägnandet av gemensamma kunskaper och kulturer. Men, språket används också som redskap för tänkandet och ger dessutom tillträde till tolkningsgemenskaper (Säljö, 2000; 2013). Språket blir ett medierande redskap för att individen ska förstå sin omvärld och fungera i den. Mediering är ett centralt begrepp inom det sociokulturella perspektivet (Säljö, 2000; 2013; Vygotskij, 1934/2010). Begreppet innebär att en individ inte möter världen direkt utan världen förmedlas med hjälp av redskap. Förutom språket som ett medierande redskap och som Vygotskij (1978) menar ingår i gruppen för psykologiska redskap, använder vi även fysiska redskap såsom pennor och böcker. För att ”...förstå hur människor fungerar och lär i sociala praktiker, hur hon utvecklar verksamheter och tar del av dem, kan vi inte bortse från att vi gör våra erfarenheter med hjälp av 
medierande redskap” (Säljö, 2000, s. 80). I praktiken är psykologiska och fysiska redskap nära förknippade med varandra. Om man exempelvis använder en karta på en idrottslektion så nyttjar man ett fysiskt redskap, men det fysiska redskapet förutsätter måttenheter och tecken som är språkliga och symboliska (Säljö, 2013). De redskap som används vid mediering ska emellertid inte bara ses som döda objekt. De har utvecklats av människan och därför också något vi samspelar med när vi handlar (Säljö, 2000). Mediering är inte heller bara något som underlättar kommunikation och förståelse. Medierande redskap kan vara abstrakta och svåra att förstå sig på för den som inte är bekant med dem. Att till exempel spela efter noter är svårt för den som inte lärt sig hur noter medierar musik (Säljö, 2013). När man som i denna studie undersöker vad som sker i en skolverksamhet blir såväl psykologiska som olika slags fysiska redskap centrala eftersom deltagarna interagerar genom dessa.

Interaktionen och kommunikationen är följaktligen viktiga för att förstå lärande och utveckling på både kollektiv och individuell nivå. En människas sätt att handla eller samtala är ständigt avhängigt kontexten och de redskap som finns tillgängliga (Säljö, 2000). Alla samtal har en historia, men också en framtid och äger rum mellan särskilda människor på en specifik plats och tid menar Mercer (1995). Samtal skildrar Säljö (2000) som ett samarbete mellan två eller flera personer. Genom att parterna talar med varandra och lyssnar på varandra tar de del av varandras analyser och slutsatser. En kontinuitet i tänkandet mellan parterna uppkommer och genom språklig kommunikation kan parterna skapa en gemensam förståelse. Den gemensamma förståelsen kan skapas oavsett om parterna är överens eller inte i en fråga eftersom de då i grunden är ense om att de inte är det. Språklig kommunikation lyfts således särskilt fram då det är "ett sätt att re-presentera världen för oss själva och för andra, ett sätt att göra den tillgänglig för diskussion och att lyfta fram de aspekter och perspektiv på händelser som är intressanta i en given situation” (Säljö, 2000, s. 114, författarens kursivering).

\section{Närmaste utvecklingszonen och stödstruktur}

Lärande behöver förstås i ett kommunikativt och sociokulturellt perspektiv. Individens egna tänkande är socialt betingat och ett resultat av det sociala samspelet med andra människor (Säljö, 2000). Vygotskij (1978; 1934/2010) använde i detta sammanhang begreppet den närmaste utvecklingszonen, vilket innebär att det finns en skillnad mellan vad ett barn kan utföra på egen hand och det ett barn kan uppnå i samarbete med andra. Dessa andra kan vara en vuxen eller mer kunniga kamrater och det är dessa personer som vägleder den mindre kompetente. Vygotskij (1978) uttrycker det som "... what a child can do with assistance today she will be able to do 
by herself tomorrow” (Vygotskij, 1978, s. 87). Han menar också att det finns en gräns för vad barn kan göra i samarbete, vilket också kan se olika ut för olika barn. Det som ett barn ska lära ska inte ligga i zonen för vad man redan behärskar, utan individens potentiella utveckling ska vara i fokus och på så sätt blir individen utmanad i sitt lärande (Vygotskij, 1978; 1934/2010). Att som lärare anpassa undervisningen till varje barns närmaste utvecklingszon blir därför centralt (Vygotskij, 1934/2010).

Imitation ingår som en del i den närmaste utvecklingszonen och ska enligt Vygotskij (1978) ses som ett återskapande och inte som en kopiering. Redan i tidig ålder och innan ett barn utvecklat ett muntligt språk imiterar de andra människor. Ett imiterande innebär att barnet lär genom att försöka förstå vad den andre gör. Vid processen sker ett aktivt närvarande som kan leda till gemenskap och barnet kan imitera olika aktiviteter som går bortom gränsen för var denne kan klara själv. Genom imitation är barnet förmöget att utföra mer krävande aktiviteter under vägledning av exempelvis en vuxen, men imitationen behöver då ske inom ramen för den närmaste utvecklingszonen (Vygotskij, 1978).

Ett vanligt begrepp som förekommer i sammanhang med den närmaste utvecklingszonen är stödstruktur (scaffolding6). Wood, Bruner, och Ross (1976) menar att det stöd som en vuxen ger i undervisningen ska vara relaterat till elevernas kompetensnivå. Om en elev har stora problem med att lösa en uppgift behöver eleven ha mer stöd från den vuxne jämfört med en annan elev som har en större kompetens för att lösa uppgiften. Utmärkande är att den vuxne förändrar sitt stöd efterhand som en elev lär och utvecklas. Först kan således den vuxne behöva ge mycket stöd, men gradvis kan stödet minska för att så småningom fullständigt upphöra då den lärande behärskar den aktuella färdigheten eller begreppet (Wood et al., 1976). Stödet kan ske genom samtal med barnet, men stödet behöver inte komma från en person utan kan vara att barnet följer skriftliga instruktioner eller använder fysiska redskap som är lämpliga för att lösa en uppgift (Säljö, 2000). Stödstruktur i denna studie kan ske med hjälp av språket exempelvis genom samtal med såväl vuxna som andra barn i en klass, men även med hjälp av andra medel såsom fysiska redskap.

En helt annan innebörd av stöd i undervisningen har begreppet lotsning. Lotsning innebär att den vuxne leder eleven förbi ett problem med hjälp av språket. Den mer kunnige lotsar eleven igenom en uppgift på ett sådant sätt att eleven klarar av den, exempelvis genom att ställa ledande frågor. Eleven behöver inte ha förstått det hon eller han svarat på utan läraren kan genom sin lotsning få en falsk bekräftelse på elevens förståelse (Kilborn \& Lundgren, 1975).

6 En direkt översättning av det engelska begreppet scaffolding är byggnadsställning. 


\section{Begreppet handlingar}

En utgångspunkt i ett sociokulturellt perspektiv är att individer handlar inom ramen för sociala praktiker. En individ handlar utifrån vilken situation denne befinner sig i (Säljö, 2000). Individen handlar utifrån sina egna kunskaper och erfarenheter och vad man bedömer att omgivningen vill eller kräver i en bestämd verksamhet (Säljö 2000; 2013; Wertsch, 1985). Individens handlingar finns således i den sociala praktiken och tänkande, kommunikation och fysiska handlingar är förbundna till situationen, det vill säga är situerade i denna kontext (Säljö, 2000). Säljö (2000; 2013) och Wertsch (1985) refererar till Leontievs 7 handlingsbegrepp där handlingar anses vara medvetna, men de kan också vara omedvetna hos individen eftersom de blivit automatiserade efter det att de utförts på ett rutinmässigt sätt. I ett sociokulturellt perspektiv ses sålunda individers handlingar som målinriktade och måste förstås utifrån det sammanhang och den verksamhet handlingarna ingår $\mathrm{i}$.

Alla våra handlingar, det vill säga vad vi gör och kan göra, och vår förståelse är delar av kontexter och kontextuella förutsättningar. Det finns därför inte först en kontext och därefter en handling utan handlingarna "ingår i, skapar och återskapar kontexter. Delar och helheter definierar varandra, och kontexten kan ses som det som väver samman en social praktik eller verksamhet och gör den till en identifierbar helhet” (Säljö, 2000, s. 135). Att förstå sambandet mellan handlingarna och kontexten är därför centralt i ett sociokulturellt perspektiv. Att socialiseras innebär med detta resonemang att individen skaffar sig kunskap om var och när olika regler är användbara menar Säljö (2000), inte att individen lär sig en rad regler utantill och sedan följer dem helt och hållet. I föreliggande studie riktas fokus mot de samtals- och skriftspråksorienterade lärarledda aktiviteter som sker i förskoleklassen där dessa aktiviteter utgörs av deltagarnas handlingar i tal och skrift, samt deras fysiska handlingar såsom gester och ansiktsuttryck. Handlingarna kommer till uttryck genom de sätt som lärare och barn och barn sinsemellan interagerar med varandra, men också genom deras sätt att interagera med den omgivande fysiska miljön.

\section{Literacy}

Internationellt, och så även i Sverige, började under 1960-talet det engelska begreppet literacy förekomma i texter om människor som lärt sig sitt lands språk, det vill säga att de är skriftspråkliga (Kullberg, 2007). Någon entydig

7 Leontiev var student och senare kollega med Vygotskij. Han utvecklade verksamhetsteorin med utgångspunkt i Vygotskijs tankar om mediering. 
översättning av begreppet literacy till svenska finns inte, och i texter kan man finna ord som till exempel litterat, skriftkultur, litteracitet och skriftspråklighet. Även det engelska begreppet literacy förekommer i svenska texter. I den här studien kommer båda begreppen literacy och skriftspråklighet att användas, men med samma innebörd.

Begreppet literacy står i ständig förnyelse (Barton, 2007). Från att begreppet från början bara omfattade skriftspråket har begreppet under åren utvidgats och fördjupats. Numera ingår såväl det talade språket som multimodala texter, det vill säga texter i vilka bilder, skrift och ljud samverkar (Kullberg, 2007; Liberg, 2007b). Barn använder hela sin repertoar av språk såsom talspråk, kroppsspråk och skriftspråk och sina sinnen såsom syn och hörsel genom ett antal olika uttrycksformer, till exempel litteratur och bild för att skapa mening (Liberg, 2007a). Denna utvidgning av begreppets innebörd har gjort att många forskare idag talar om det i pluralform, alltså literacies 8 (Barton, 2007; Lankshear \& Knobel, 2003; Skoog, 2012). Säljö (2013) poängterar att skriftspråkliga aktiviteter, det vill säga literacy, är komplexa och varierade. Literacy berör inte enbart den tekniska färdigheten att avkoda ord, "utan långt mer om att kunna dra slutsatser, att göra associationer, att koppla det man läser till vad man vet om världen i övrigt och vad man läst i andra sammanhang, att förstå men ändå kunna förhålla sig kritisk och så vidare” (Säljö, 2013, s. 208). I föreliggande studie kommer begreppet literacy omfatta tal (verbalt), skrift (läsning och skrivning) och bilder.

\section{Literacy som social aktivitet}

Barton (2007) nyttjar tankemodellen skriftspråkets ekologi i samband med studier av människors användning av literacy. Användandet av skriftspråket är en mänsklig verksamhet som sker i samspel med omgivningen. Literacy är således en social aktivitet som Barton framhåller kan skildras genom begreppet literacy practices (literacypraktiker). Människor ingår i olika domäner och sociala relationer där olika typer av literacy används, vilket gör att det sociala sammanhanget där literacy events (literacyhändelser) sker, behöver beskrivas. Barton menar att

Literacy events are the particular activities where literacy has a role; they may be regular repeated activities. Literacy practices are the general cultural ways of utilizing literacy which people draw upon in a literacy event (Barton, 2007, s. 37).

8 I detta sammanhang förekommer även begreppet multiliteracies för att visa på den mångfald av användningsområden och funktioner som begreppet innehar. 
Det ges många tillfällen i en människas vardagsliv där läsandet och skrivandet får stor betydelse. Det betyder att det förekommer många literacy events i vårt dagliga liv. De kunskaper vi har om läsning och skrivning använder vi sedan i olika situationer och i olika literacy practices.

Liknande tankegångar kring begreppen har Street (2000). Han menar att literacy practices står för det sociala och kulturella användandet av literacy i olika situationer medan literacy events kan ses som en situation där en aktivitet kring skrift finns och som då är uppkommen ur denna praktik. De båda begreppen står därmed i nära förbindelse med varandra. Literacy events går många gånger att iaktta till skillnad från literacy practices där samma händelser kan vara mer osynliga. "You can photograph literacy events but you cannot photograph literacy practices" (Street, 2000, s. 21).

Människor lär sig att olika literacy practices passar för olika roller och att det i vissa roller finns en maktbalans som är ojämlik. Barton (2007) menar att det ligger en skillnad i hur literacy används beroende på om det är påtvingat eller självvalt. Han sätter detta i relation till Streets (1993) begrepp om dominant literacy och vernacular literacy. Dominant literacy bärs i hög grad upp av olika samhällsinstitutioner såsom skolan, medan vernacular literacy utgår ifrån de handlingar som människor gör inom ramen för det privata dagliga livet. Dominant literacy har högst status och är därför det som blir styrande i ett samhälle.

Literacy är baserat på ett system av symboler som människor använder för att kommunicera med varandra menar Barton (2007). Ett exempel på ett symbolsystem är skriftspråket, vilket bygger på vårt talade språk. Literacy ingår i vårt sätt att tänka och därmed har begreppet ett förhållande till människors attityder, värderingar och känslor, vilket också styr var och ens handlingar och engagemang. Detta betyder att de erfarenheter vi har av literacy, positiva eller negativa, påverkar våra handlingar. Dessutom har literacy en historia och människors liv innehåller, från barndom fram till vuxen ålder, därför många och av varandra olika erfarenheter av literacy. Lärandet kan därför inte heller begränsas till en bestämd arena såsom skolan. Såväl barn som vuxna utvecklar ständigt literacy, vilket inverkar på den personliga utvecklingen. Slutligen menar Barton att dagens literacypraktiker har skapats från det förflutna, men är aldrig detsamma genom tiderna. I begreppet literacy ingår på så sätt också en social och kulturell historia. När man talar om literacy blir således händelser där skriften praktiseras betydelsefulla att undersöka. I föreliggande studie används begreppet literacy events för att identifiera händelser där lärare och barn är involverade i olika skriftspråksorienterade aktiviteter i de undersökta förskoleklasserna. De identifierade händelserna med de mönster som framträder vid analysen av dessa kan förstås som delar av en literacypraktik. 


\section{Emergent literacy}

Under tidigt 1980-tal började forskare studera användningen av skriftspråket i olika sociala praktiker (se exempelvis Heath, 1983; Scribner \& Cole, 1981; Street, 1984). En förändring från den tidigare synen på läsning och skrivning där framför allt kognitiva förmågor varit i fokus kan därmed skönjas (Liberg, 1990).

Den tidsperiod hos barnet som leder till skriftspråklighet har kommit att benämnas emergent literacy (Kullberg, 2007). Den nyzeeländska forskaren Clay anses vara en av de forskare som banade vägen för emergent literacyforskningen. I sina studier fann hon att många barn utforskar skriftspråket i samspel med andra människor långt innan den formella läsoch skrivinlärningen tar vid (Clay, 1966; 1975). Utforskandet av exempelvis bilder, text och symboler sker inte vid ett speciellt tillfälle eller på en särskild plats utan i de vardagliga sammanhang som barnet befinner sig i. I detta sammanhang lyfts vuxnas, och framför allt föräldrarnas betydelsefulla roll fram. Genom att barnet och föräldrarna samtalar och samspelar i olika läs- och skrivsituationer eller att barnet på eget initiativ utforskar skriftspråket och här får stöd och uppmuntran från föräldrarna tillägnar sig barnet skriftspråklig kompetens (Teale \& Sulzby, 1986).

I början av 1980-talet fick forskningen kring emergent literacy en större genomslagskraft genom att antropologer som Taylor och Heath började intressera sig för skriftspråkstillägnande utifrån ett etnografiskt synsätt. Taylor (1983) myntade begreppet family literacy då hon följde sex familjer under tre år och undersökte hur barnen utvecklade kunskap om skriftspråket i deras egna hem. Denna, liksom Heaths (1983) numera klassiska studie, visar på liknande sätt att föräldrarnas sociala och kulturella tillhörighet är av stor betydelse för hur barnen socialiseras in i skriftspråket. Heaths studie visar att föräldrarnas olika sätt att bemöta och utveckla barnens språk får stor betydelse för barnen när de sedan möter skolans mer formella undervisning.

Scribner och Coles (1981) undersökning anses också vara en klassiker i detta sammanhang där studien går utanför skolans ram. En slutsats som Scribner och Cole drog var att olika typer av literacy förvärvades och användes för olika sociala och kulturella ändamål. Paralleller kan utifrån en svensk kontext dras till Fasts (2007) studie där betydelsen av barns språkliga möten i hemmiljön påvisas. De första mötena med skriftspråket kan se mycket olika ut beroende på vilken social och kulturell bakgrund barnet har. Somliga barn ingår redan i tidig ålder i olika skriftspråkliga aktiviteter, medan andra på allvar kommer i kontakt med skriftspråket först i skolåldern (Fast, 2007).

De senaste åren har en ny forskningsinriktning kallad early childhood literacy vuxit fram ur forskningen om emergent literacy. Ett antagande 
inom early childhood literacy forskningen är att barnen under sin barndom befinner sig i sin literacy och agerar med skriftspråket på sina egna villkor och utifrån vad som är meningsfullt för dem själva. Man ser på literacy som något som ett barn föds med, man är alltså litterat från början och inte som ur ett emergent literacy perspektiv, något som växer fram (Gillen \& Hall, 2003). Teale och Sulzby (1986) uttrycker det som "...children in the process of becoming literate, as the term emergent indicates (Teale \& Sulzby, 1986, s. xix, författarnas kursivering). Björklund (2008) som i sin avhandling utgår ifrån ett early childhood literacy perspektiv uttrycker skillnaden som en fråga om att bli eller vara litterat. Hon menar att med ett early childhood literacy perspektiv kan man se på litteracitet som olika tillstånd som finns och förändras genom att barn upptäcker och tillägnar sig ny mening i mötet med litteracitetshändelser. Yngre barn testar och undersöker hela tiden sin omgivning och därför tar inte deras litteracitet en bestämd väg. Björklund menar på så sätt att ”...litteracitet i de tidiga åren snarare är än växer fram och blir litteracitet” (Björklund, 2008, s. 56, författarens kursivering).

\section{Sammanfattning}

I detta kapitel redogörs för det sociokulturella perspektivets syn på lärande och utveckling där språket har en central roll. Inom det sociokulturella perspektivet framhålls betydelsen av att undervisningen anpassas till barnets närmaste utvecklingszon där stödstrukturer behöver vara relaterade till barnets kompetensnivå. I kapitlet beskrivs begreppet handlingar. Centralt är att individers handlingar behöver förstås utifrån det sammanhang och den verksamhet handlingarna ingår i. Vidare redogörs för literacyforskningens centrala antaganden om literacy som en social praktik.

\section{Det sociokulturella perspektivet i denna studie}

I detta kapitel har det sociokulturella perspektivet presenterats, vilket utgör studiens teoretiska ram. Centralt i ett sociokulturellt perspektiv är att mänskliga handlingar situeras i sociala praktiker (Säljö, 2000). I denna studie är förskoleklassen en sådan praktik. Genom att studera lärares och barns handlingar i samtals- och skriftspråksorienterade lärarledda aktiviteter i förskoleklassen möjliggörs att dra slutsatser om vilka förutsättningar för barns samtalande och skriftspråkande som skapas i interaktion mellan läraren och barnen i de lärarledda aktiviteterna. Det sociokulturella perspektivet ger på så sätt stöd åt studiens syfte och 
frågeställningar och används för att analysera och förstå det insamlade datamaterialet. 


\section{Metod}

I följande kapitel redovisas inledningsvis valet av metod. Därefter beskrivs hur den empiriska undersökningen genomförts där bland annat de metoder som använts vid datainsamlingen och min egen erfarenhet av det fält som studerats redovisas. Sedan följer en redogörelse för hur det insamlade datamaterialet bearbetats och analyserats. Kapitlet avslutas med att behandla intern logik och de forskningsetiska överväganden som gjorts i relation till denna studie.

\section{Val av metod}

Föreliggande studie har inspiration från etnografisk ansats. Begreppet etnografi förekommer i olika sammanhang och på skilda sätt, vilket gör begreppet svårdefinierat (Beach, 2008; Bryman, 2011; Fangen, 2005; Hammersley \& Atkinson, 2007). Etnografi översätts av Fangen (2005) med ordet folkbeskrivning. Enligt Delamont (2012) innebär begreppet att man som forskare försöker förstå den kultur som deltagarna befinner sig i, samt förstå hur deltagarna uppfattar den. För att fånga de händelser och handlingar som sker och som för deltagarna är helt naturliga och vardagliga, behöver etnografen befinna sig i deltagarnas sociala sammanhang under en längre tidsperiod (Alvesson \& Sköldberg, 2008; Fangen, 2005; Hammersley \& Atkinson, 2007). I sökandet efter mönster som kan sägas vara kännetecknande för vad som sker i förskoleklassen riktas därför intresset mot lärares och barns handlingar i denna verksamhet.

\section{Urval och tillträde}

För att kunna göra en etnografisk studie behöver forskaren få tillträde till det fält som ska studeras. Hammersley och Atkinson (2007) kallar de personer som ger forskaren tillträdet för "gate-keepers". Dessa personer innehar nyckelroller på fältet och är de som bestämmer om forskaren ska få tillträde till den miljö som hon eller han vill studera eller inte. Efter att ha besökt olika kommuners hemsidor där skolor presenterar sin verksamhet i förskoleklass och årskurs 1 och om de aktivt arbetar för en fungerande övergång häremellan, ringde jag till tre rektorer på olika skolor. Mitt val av dessa tre skolor grundade sig, förutom att de hade en verksamhet som riktade sig till förskoleklass och årskurs 1, således också på att skolorna själva uttrycker att de har ett fungerande samarbete mellan verksamheterna. 
Dessutom avgjordes valet av att jag själv inte tidigare haft någon kontakt eller arbetsrelation med skolorna.

Två av rektorerna gav sin tillåtelse direkt per telefon, men med förbehållet att ansvariga för de tänkta förskoleklasserna också gav sitt medgivande. En telefonkontakt togs med de respektive namn jag fått från rektorerna och efter att jag presenterat studien för dem, gav de sina samtycken. Den tredje rektorn ville ha ett personligt möte med mig innan ett svar om deltagande kunde ges. Under mötet gav rektorn klartecken för att skolan kunde tänka sig att delta i studien. Rektorn och jag besökte tillsammans de tänkta förskollärarna direkt efter vårt möte och jag fick möjlighet att då presentera studien även för dem. Urvalet kan därmed beskrivas som ett kedjeurval, vilket innebär att forskaren tar kontakt med några personer som är lämpliga utifrån studiens syfte, vilka sedan används för att få kontakt med ytterligare relevanta personer (Bryman, 2011).

\section{Deltagande lärare och barn}

I studien ingår tre förskoleklasser från tre olika skolor. I varje förskoleklass finns cirka 20-25 barn uppdelat på ungefär lika många flickor som pojkar. Till varje klass finns två förskollärare och/eller grundskollärare kopplade. Stundtals kan även fritidspedagoger arbeta i verksamheten. Då deltagarna i studien består av olika personalkategorier kommer begreppet lärare användas som ett samlingsnamn. Jag har även valt att använda begreppet barn istället för elever eftersom det oftast användes av deltagarna själva.

\section{Delvis deltagande observation}

Vid etnografiska studier är det vanligt att använda sig av olika datainsamlingsmetoder (Fangen, 2005; Howitt 2010). Denna studie utgår framför allt ifrån deltagande observationer där fältanteckningar skrivits för att dokumentera dessa, men jag har även samlat in dokument från fältet och haft informella samtal med lärare och barn. Deltagande observation kommer enligt Fangen (2005) till användning då forskaren vill beskriva vad människor säger och gör när de befinner sig i sina naturliga sammanhang, vilket på så sätt kan vara ett passande val av metod utifrån syftet med denna studie.

Observationerna är gjorda under veckans alla arbetsdagar. De genomfördes vid olika tidpunkter under dagen även om ett större antal av observationerna utgick ifrån klassernas första pass på morgonen med start omkring klockan 8.00. Enligt Hammersley och Atkinson (2007) bör forskaren sprida ut sina dagar och tider när hon eller han observerar 
eftersom det minimerar risken för att dra slutsatser om händelser som bara sker vid ett bestämt tillfälle i veckan. Sju observationer har genomförts i varje förskoleklass under perioden september 2012 och april 2013. Varje observation varade i cirka två timmar och omfattar alla de aktiviteter som skedde i verksamheten, såväl inne som ute. Tabell 1 visar en sammanställning av antalet observationer, antalet timmar per observation och tid i timmar för lärarledd aktivitet i varje observation.

Tabell 1. Antal observationer, antal timmar per observation och tid $i$ timmar för lärarledd aktivitet $i$ varje observation.

\begin{tabular}{lccc}
\hline Förskoleklass & $\begin{array}{l}\text { Antal } \\
\text { observationer }\end{array}$ & $\begin{array}{l}\text { Antal } \\
\text { timmar/ } \\
\text { observation }\end{array}$ & $\begin{array}{l}\text { Tid i timmar för } \\
\text { lärarledd aktivitet } \mathrm{i} \\
\text { varje observation }\end{array}$ \\
\hline Blåsippan & 7 & 2 & $1: 15$ \\
Gullvivan & 7 & 2 & $1: 00$ \\
Smörblomman & 7 & 2 & $1: 15$ \\
Totalt & 21 & 42 & $24: 30$ \\
\hline
\end{tabular}

Jag har även observerat de tre förskoleklasserna under årskurs 1, men valt att fokusera på förskoleklassen i denna studie.

Min roll som forskare kan beskrivas som den som Fangen (2005) benämner som delvis deltagande observatör. Det är en vanlig observatörsroll inom den etnografiska traditionen. Forskaren deltar då i det sociala samspelet, men inte i de aktiviteter som deltagarna ägnar sig åt (Fangen, 2005). Redan under studiens inledande skede samtalade jag med lärarna om vilken roll jag ville ha i klassrummet. Min utgångspunkt var att inte delta i aktiviteterna, men ändå vara i närheten. Ofta placerade jag mig strax bakom samlingsringen och med detta ville jag visa att jag deltar, men lite på distans. Min förhoppning med en sådan placering var också att dra till mig så lite uppmärksamhet som möjligt och att deltagarna helst skulle glömma att jag var där. Under mina första observationer i de besökta förskoleklasserna upplevde jag dock att barnen och lärarna till exempel ofta sneglade åt mitt håll under samlingarna, men med tiden och antalet observationer blev blickarna allt färre. Mellan det första och sista observationstillfället förflöt cirka 8 månader. Under denna tid besökte jag skolorna med jämna mellanrum, vilket kan ha bidragit till att jag blev ett välbekant ansikte för deltagarna och därmed inte någon som ådrog sig mer 
uppmärksamhet än någon annan. Deltagarna var också vana vid andra vuxenbesök än mina. Emellanåt var exempelvis föräldrar eller mor- och farföräldrar på besök samtidigt som jag. Att deltagarna därmed även var vana vid att andra personer fanns där än de som vanligtvis ingår $\mathrm{i}$ verksamheten, menar jag minskar risken för att deltagarna förställer sig eller att aktiviteter tillrättaläggs. Besök blir således en naturlig del av verksamheten. Med detta, och med stöd av Granström (2004), anser jag det vara troligt att observationerna påverkat de situationer som studerats $\mathrm{i}$ begränsad grad, vilket kan visa på situationernas autenticitet. För att en situation ska anses vara autentisk, det vill säga inte avvika från det vanliga, behöver den situation som studerats vara representativ för den typ av interaktion som forskaren ämnar beskriva (Granström, 2004).

Ibland kunde jag emellertid uppleva det svårt att inte aktivt delta i de aktiviteter som pågick. Jag fick framför allt i början av studien frågor från barnen om jag exempelvis ville läsa en saga för dem eller vara med och spela ett spel. Jag svarade alltid med att hänvisa till mitt första besök i klassen där jag berättat att jag bara var där för att se vad de gjorde i klassen och att jag inte själv skulle delta i några aktiviteter. Med tiden blev sådana frågor allt färre. Under hela studiens gång fick jag emellertid frågor där barnen ville ha min hjälpande hand med praktiska sysslor till exempel att dra upp dragkedjan på en jacka eller knyta ett skosnöre, vilket jag alltid hjälpte till med.

Jag upptäckte ganska tidigt att det inte alltid var så lätt att hålla fokus under en observation. Jag ville vara där "det hände" och jag gick därför i snabb takt från exempelvis ett rum till ett annat och från en samling barn till några andra. Efter ett tag insåg jag att man som observatör inte kan registrera allt som händer i en miljö, vilket också Fangen (2005) poängterar inte är möjligt. Även Hammersley och Atkinson (2007) anser att en forskare är i behov av att avgränsa sig. De menar att forskaren måste göra en kompromiss och välja mellan djup eller bredd då observation på flera platser medför mindre tid på var och en av dessa. Jag valde därför många gånger att vara kvar i ett rum under en hel aktivitet och fokusera på just det som hände där och då.

\section{Fältanteckningar}

Etnografiska fältanteckningar förordas vara grundliga och ge en känsla av närvaro (Fangen, 2005; Larsson, 2005), vilket Larsson (2005) framhåller har betydelse för en studies kvalitet. Fältanteckningar bör också innehålla direkta citat (Fangen, 2005; Hammersley \& Atkinson, 2007). Hammersley och Atkinson (2007) rekommenderar att beroende på vad som är passande behöver man anteckna så nära observationen som möjligt, men optimalt är att "...make notes during actual participant observation” (Hammersley \& 
Atkinson, 2007, s. 176). Därefter behöver observatören så snart som möjligt och med hjälp av minnet och fältanteckningar renskriva anteckningarna till beskrivningar (Fangen, 2005; Heath \& Street, 2008). Under tiden för observationerna förde jag löpande fältanteckningar med hjälp av penna och anteckningsblock. Anteckningarna innehåller en blandning av korta ord och meningar, men också mer eller mindre exakta citat från deltagarna. Ett exempel på när avsteg kan ha gjorts från deltagarnas exakta uttalanden är när de använt talspråksord. Svenska språknämnden (2005) rekommenderar att när man i skrift återger vad någon berättat i vanlig samtalsstil behöver man vanligtvis redigera formuleringarna så att de blir läsbara.

Jag har i nära anslutning till observationerna renskrivit alla anteckningar till beskrivningar på dator. Oftast skedde detta under en och samma dag, men ibland fortsatte också arbetet dagen efter. Jag har strävat efter att ge så fylliga beskrivningar som möjligt för att på så sätt tydliggöra resultaten. Larsson (2005) menar att en kvalitetsaspekt i studier är innebördsrikedom vilket betyder att resultatbeskrivningen ska vara rik på innebörd, fånga det väsentliga samtidigt som den även innefattar nyanserna.

Enligt Fangen (2005) bör fältanteckningarna också innehålla tolkningar, medan Hopkins (2008) menar att de tolkningar som observatören gör ska antecknas efter det att observationen är gjord och inte under den. Jag har fältanteckningar där jag gjort tolkningar under observationen, men också sådana där detta inte finns utan en första tolkning har istället gjorts efter renskrivningen av observationen. Alla tolkningar, men också de analyser och frågor som uppstod hos mig själv under observationerna har lagts i särskilda dokument.

\section{Dokument och informella samtal}

De dokument som samlats in från fältet är främst sådana som ger en bakgrund till en aktivitet eller händelse och därför har detta material inte varit en del i analysen. Dokumenten kan exempelvis vara teckningar som jag har fått från barnen. De insamlade dokumenten har producerats under den tid som jag varit närvarande i klasserna.

De informella samtal som förts har skett spontant både före, under och efter en aktivitet. Jag har småpratat med deltagarna rent allmänt, men vi har också pratat direkt kring de aktiviteter som de har gjort. Med lärarna har jag till exempel samtalat om vad en kommande aktivitet ska innehålla och med barnen om hur de exempelvis upplevt att arbeta med en uppgift. Med barnen har samtalen förts enskilt, men också i mindre grupper. Samtalen har noterats i samma anteckningsblock som fältanteckningarna och även dessa anteckningar har renskrivits på dator. Detta material har använts i analysen som stöd till beskrivningarna av observationerna. För att komma 
deltagarna nära behöver forskaren delta i det vardagliga samspelet och samtala med dem. Det är emellertid viktigt att inte komma deltagarna "för nära” (Fangen, 2005).

\section{Närhet och distans till fältet}

Inom den etnografiska forskningsprocessen används begreppet "go native", vilket innebär att man som forskare behöver se upp med att man inte kommer deltagarna för nära och blir en av deltagarna (Bryman, 2011; Hammersley \& Atkinson, 2007). Det handlar om att komma deltagarna så nära att man som forskare kan ge en rättvis bild av fältet, men samtidigt också hålla en viss distans för att kunna upprätthålla en kritisk blick (Fangen, 2005). För att undvika att komma alltför nära rekommenderar Fangen att man då och då stannar upp och kritiskt reflekterar över sina fältanteckningar och sitt förhållningssätt. Jag har under forskningsprocessen bearbetat det empiriska materialet med frågor som "var det verkligen det här jag såg eller var det något jag ville se?” Detta för att försöka hålla den distans som Fangen talar om och som är nödvändig för att forskaren ska kunna bevara sin kritiska blick.

Att som forskare vara förtrogen med det fält som studeras kan både ses som en möjlighet, men också som ett hinder i forskningsprocessen (Hammersley \& Atkinson, 2007). Eftersom jag har erfarenhet av det fält som studerades, både som grundskollärare, lärarutbildare och förälder, försökte jag komma bortom det som kan vara självklart och förgivettaget. Det gjorde jag genom att försöka anamma en position till fältet "som om jag inte visste något” om den, vilket också är ett råd som Fangen (2005) ger. Hon menar att det är ett synsätt som behövs för att ny kunskap ska kunna genereras. I praktiken försökte jag förhålla mig öppen och nyfiken till fältet så att mina förhandsantaganden inte skulle bli alltför styrande. Enligt Heath och Street (2008) handlar det om att "...making the familiar strange" (s. 32).

Att som forskare vara förtrogen med fältet genom att tala samma språk och ha erfarenhet av liknande aktiviteter och händelser upplevde jag även som en tillgång. Vid samtalen med deltagarna kunde jag ofta låta dem "prata på” eftersom jag förstod i vilken kontext de rörde sig. Det gjorde också att jag upplevde att vi hade en gemensam referensram och med detta följde att det kändes som att det skapades en slags förtrolighet mellan mig och deltagarna. Då forskaren redovisar sin förförståelse genom att berätta om sina personliga erfarenheter av det fält som studeras talar Larsson (2005) om perspektivmedvetenhet vilket han också lyfter fram som ett kvalitetskriterium. Redovisningen blir viktig eftersom tolkningarna görs utifrån denna förförståelse (Larsson, 2005). 


\section{Analys av det empiriska materialet}

I tabell 3 visas den identifikations- och transkriptionsmall som har använts för att skildra valda citat i det empiriska materialet.

Tabell 3. Identifikations- och transkriptionsmall

\begin{tabular}{ll}
\hline Symboler & Innebörd \\
\hline Pojke; Flicka & oidentifierbar pojke; flicka \\
Pojke 1; Flicka 1 & $\begin{array}{l}\text { siffror används för att skilja mellan } \\
\text { olika barns repliker som förekommer } \\
\text { inom samma exempel }\end{array}$ \\
Läraren & läraren i förskoleklassen \\
Marcus; Ebba & barn i förskoleklassen \\
Alla & $\begin{array}{l}\text { flera barn uttrycker något och det går } \\
\text { inte att urskilja någon specifik individ }\end{array}$ \\
Några & $\begin{array}{l}\text { några barn uttrycker något och det går } \\
\text { inte att urskilja någon specifik individ }\end{array}$ \\
/S-a-n-d-r-a/ & ihopljudning eller utljudning av ord \\
[...] & utelämnade turer \\
(...) & längre paus \\
& $\begin{array}{l}\text { kommentarer, tilläggsinformation om } \\
\text { vad deltagarna gör }\end{array}$ \\
\hline
\end{tabular}

Som tidigare beskrivits har till viss del en första tolkning och analys gjorts under genomförandet av fältarbetet, vilket är vanligt vid denna typ av forskning (Fangen, 2005; Hammersley \& Atkinson, 2007). Denna bearbetning har lagt en första grund till att börja se mönster i det empiriska materialet, men det var först efter avslutat fältarbete som en mer genomgripande kodning av materialet gjordes. Empirin ligger således som 
grund för kodningsprocessen och därmed kan analysen enligt Braun och Clarke (2006) mer betecknas som induktiv än deduktiv.

Inom kvalitativ forskning är tematisk analys en vanligt förekommande metod. Tematisk analys innebär att forskaren kodar sitt datamaterial för att på så sätt identifiera olika teman. Analysmodellen består av sex steg där det första steget handlar om att göra sig bekant med sitt datamaterial (Braun \& Clarke, 2006). Detta gjordes i samband med att fältanteckningarna renskrevs till beskrivningar samt att eventuella tillhörande tolkningar och analyser till dessa skrevs ner på ett särskilt dokument. Fortsatt bekantskap med materialet gjordes också genom att ofta gå tillbaka och läsa dessa dokument under tiden som datainsamlingen pågick. Det empiriska materialet är insamlat från tre olika skolor, men analyseras som en helhet då avsikten inte är att jämföra dem med varandra utan snarare hitta fenomen som bildar mönster för de handlingar som sker i förskoleklassverksamheten. Under det andra steget skapades initiala koder. Vid genomläsningen av varje beskrivning som finns för respektive observationstillfälle fördes en nära och öppen kodning. Det innebär enligt Howitt (2010) att kodningen ligger i nära anslutning till de beskrivningar som görs. Koderna skrevs i marginalen på textmaterialet och består av alltifrån något enstaka ord till längre meningar, exempelvis "veckodagsång" eller "läraren ber barnen räcka upp handen”. De framskrivna koderna lades i ett särskilt dokument som efter många gångers genomläsning och färg och/eller figurkodning kunde ordnas i grupper där teman då också tog form. Att formulera teman är analysmodellens tredje steg. Tabell 2 visar hur ett tema konstruerades genom att åskådliggöra relationen mellan koder och underteman i temat "Samtalets möjligheter och begränsningar”. 
Tabell 2. Exempel på koder, undertema och tema

\begin{tabular}{lll}
\hline Koder & Undertema & Tema \\
\hline Undrar hur vädret är & Frågebank &
\end{tabular}

Undrar vad som händer i ～Frågebank

helgen

Barnen berättar efter hur Turordning

de sitter i ringen

Samtalets möjligheter

och begränsningar

Går laget runt

Turordning

Ber barnen räcka upp Handuppräckning

handen

Många av barnen räcker

upp sin hand

Handuppräckning

Under det fjärde steget gjordes en kritisk granskning av de identifierade temana. Här granskades respektive temas samstämmighet och i samband med det lästes materialets beskrivningar om igen. Jämförelser mellan koder, teman och data gjordes. De arbetsnamn som temana haft och där vissa också bytt namn efter vägen preciserades och fastställdes. Utgångspunkten har varit att låta datamaterialet visa vägen för skapandet av teman. Under det femte steget gjordes ännu en kritisk granskning för att se om temana bidrog till att ge svar på studiens syfte och frågeställningar. Till sist, under det sjätte steget, gjordes ett urval av citat som ska belysa de olika temana.

Efter att ovanstående analysmodell genomförts analyserades även datamaterialet med hjälp av begrepp från tidigare forskning (se vidare kapitel 2) och utifrån de teoretiska utgångspunkterna (se vidare kapitel 3). Frågor som exempelvis ställdes till datamaterialet var: "Vilken typ av samtalsstruktur framträder?" och "Vilka medierande redskap använder läraren och barnen?”

Den ovanstående beskrivna analysprocessen kan tolkas som att processen gått som en rak linje från det ena steget till det andra. I praktiken har processen mera varit "fram och tillbaka mellan stegen" och 
beskrivningen ska därför mer ses som en översiktlig redogörelse över hur analysprocessen gått tillväga. Enligt Braun och Clarke (2006) är detta ett vanligt tillvägagångssätt vid kvalitativ analys.

\section{Kvalitetsaspekter i forskningsprocessen}

Ovanstående avsnitt har behandlat kvalitetsaspekter som innebördsrikedom och perspektivmedvetenhet. Även situationernas autenticitet har behandlats. I relation till studiens kvalitet har även kvalitetskriterierna intern logik och forskningsetiska överväganden uppmärksammats, vilka beskrivs nedan.

\section{Intern logik}

Ett vetenskapligt arbete ska vara som ett slutet system där alla delar hänger samman, det vill säga att det råder harmoni mellan forskningsfrågan, antaganden om forskning, datainsamlingen, analystekniken, resultaten och diskussionen (Larsson, 2005). Larsson uttrycker harmonin mellan arbetets del och helhet som intern logik, vilket han också lyfter fram som ett kvalitetskriterium. Utgångspunkten är att syfte och forskningsfråga styr valet av datainsamlingsmetod och analys.

För att skapa en intern logik har studiens inledande syfte, det vill säga att studera lärares och barns handlingar i förskoleklassen, varit ledande när det gäller val av datainsamlingsmetod. Studiens inledande syfte preciserades dock senare till lärares och barns handlingar i samtals- och skriftspråksorienterade lärarledda aktiviteter för att öka den interna logiken ytterligare. Delvis deltagande observation som datainsamlingsmetod valdes som den mest lämpliga för att ge svar på detta. Presentationen av tidigare forskning och teoretiska utgångspunkter har skett med avseende på den relevans de har för studien och dess forskningsfrågor. Det har till följd att i resultaten återfinns begrepp från tidigare forskning och teoretiska utgångspunkter vilka också bidrar till att diskutera och förstå resultaten.

\section{Forskningsetiska överväganden}

Vetenskapsrådet (2011) rekommenderar forskaren att redovisa hur deltagarna i studien behandlats, det vill säga hur individskyddskravet upprätthållits. I individskyddskravet ingår kravet om informerat samtycke. Informerat samtycke innebär att de som deltar i studien ska få information om projektet för att därefter kunna meddela om de vill delta eller inte. 
I ett inledande skede av denna studie tog jag som tidigare nämnts, muntlig kontakt med skolornas rektorer för att informera om studien och få deras samtycke till deltagande. Jag förklarade i vilket sammanhang studien ingår, samt att syftet med licentiatstudien var att följa den verksamhet som sker i förskoleklassen. Även de förskollärare och grundskollärare som ingår i studien har fått denna information och efter detta har de gett sitt samtycke till att medverka. De lärare som arbetar i förskoleklasserna på respektive skola skickade sedan i samband med ett veckobrev ut samma information till barnen och deras vårdnadshavare. Brevet innehöll också uppgifter där vårdnadshavarna kunde få kontakt med mig om de undrade över något eller för att meddela att deras barn inte skulle ingå i studien, men någon sådan kontakt togs aldrig. Vid första observationstillfället med varje förskoleklass presenterade jag mig och berättade varför jag var där, samt hur ofta jag skulle komma på besök. Eftersom jag främst riktade mig till barnen försökte jag förklara på ett så konkret och tydligt sätt som möjligt. Jag avlutade med att fråga om någon undrade över något, men fick inte någon fråga. Däremot kom barn fram till mig vid senare observationstillfällen och ville veta mer om mig som person, som till exempel var jag bodde eller om jag hade några barn. Någon gång fick jag också frågan om vad jag skrev i mitt anteckningsblock. Mitt svar blev alltid "Jag skriver vad ni gör i förskoleklassen” och med det upplevde jag att barnen nöjde sig. Jag fick också vid ett flertal tillfällen möjlighet att presentera mig själv och studien när barnens närstående var på besök samtidigt som jag. Vid dessa tillfällen upplevde jag att det fanns ett genuint intresse för mitt arbete. Samma upplevelse har jag med de lärare som ingår i studien. Många av dem sa till exempel att de tyckte att det var roligt att någon intresserade sig för just deras verksamhet, vilket de inte ansåg vara vanligt.

Vidare rekommenderar Vetenskapsrådet (2011) forskaren att redovisa hur krav på anonymisering, tystnadsplikt och konfidentialitet behandlats. Alla person- och förskoleklassnamn samt namn på platser har ersatts med fingerade namn och på så sätt kan kravet om anonymitet anses vara uppfyllt. Krav på tystnadsplikt handlar om att forskaren så långt som det är möjligt inte berättar varifrån empirin är hämtad vilket även är intentionen i föreliggande studie. Utskrivet datamaterialet förvaras inlåst och datorn där materialet finns sparat har ”logg in”. Därmed kan kravet på konfidentialitet anses vara uppfyllt. Dessutom rekommenderar Vetenskapsrådet forskaren att redovisa i vilket syfte det empiriska materialet nyttjas. Allt insamlat datamaterial kommer endast att användas till forskningsändamål. 


\section{En presentation av studiens förskoleklasser}

Följande kapitel ger en beskrivning av de tre förskoleklasser som ingår i studien. Beskrivningen syftar till att ge läsaren möjlighet att sätta in de efterföljande resultatkapitlen i ett sammanhang och ska förstås som en sammanfattande och förenklad version av de tre förskoleklassernas verksamheter.

\section{Lärarna och barnen}

Antalet barn som går i de respektive förskoleklasserna Blåsippan, Gullvivan och Smörblomman är ungefär detsamma, cirka 20-25 barn i varje klass. Varje klass består av ungefär lika många flickor som pojkar. Ibland sker aktiviteterna i grupp och barnen är då indelade i två ungefär lika stora grupper. Dessa två grupper är bestämda över hela förskoleklassåret och består av nästan lika många flickor som pojkar. Förskoleklassen Gullvivan har emellertid ingen schemalagd och därmed ingen planerad gruppindelning på sitt schema.

I förskoleklassen Blåsippan heter lärarna Ulla och Evy. De är båda förskollärare och har arbetat i yrket under många år. Ulla är huvudansvarig för verksamheten i förskoleklassen och Evy kommer in då de ska arbeta med barnen i grupp. Antingen arbetar Ulla och Evy med samma innehåll även om de har var sina grupper i skilda rum eller så har Evy skapande arbete med sin grupp medan Ulla har en skriftspråksaktivitet med den andra gruppen. När Ulla och Evy arbetar med olika innehåll byter de grupper med varandra under dagen.

I förskoleklassen Gullvivan heter lärarna Mona, Birgitta och Susanne. Mona och Birgitta är förskollärare och har mångårig erfarenhet av yrket. Susanne är fritidspedagog och även hon har många års erfarenhet av yrket. En fast timme i veckan har Mona, Birgitta och Susanne arbetslagsmöte tillsammans med andra kollegor och då ersätts de av två fritidspedagoger. Under den tid Mona, Birgitta och Susanne är borta har barnen alltid fri lek. Vanligtvis arbetar två av de tre lärarna under en arbetsdag. De två lärare som arbetar brukar alternera ansvaret över en aktivitet, men ibland tar en av dem ett mer övergripande ansvar.

I förskoleklassen Smörblomman heter lärarna Helene och Ella. Helene är förskollärare och Ella 1-7 lärare med inriktning mot de yngre barnens lärande i grundskolan. Helene har arbetat som förskollärare i många år medan Ella har några års erfarenhet av att arbeta i förskoleklass och 
grundskolans tidiga år. Helene har huvudansvaret för verksamheten och är den person som barnen träffar mest. Helene är emellertid ledig en dag i veckan och då tar Ella över ansvaret för verksamheten. Ella arbetar även andra dagar i förskoleklassen exempelvis när klassen är delad i två grupper. Vanligtvis arbetar Helene och Ella med samma innehåll i sina respektive grupper, men de befinner sig i skilda rum.

\section{Förskoleklassernas lokaler}

Gemensamt för de tre förskoleklasserna är att de har ett eget klassrum att tillgå. I klassrummet sker alltid någon form av aktivitet under den tid som verksamheten pågår. De tre klassrummen är fysiskt utformade på ett liknande sätt.

Klassrummen är möblerade med runda och/eller ovala bord och stolar, samt med en soffa. På de flesta av borden står burkar med blyertspennor, tuschpennor och suddgummin. Borden är placerade så att de lämnar fria golvytor för lek och samling i helklass. Längs väggarna finns barnens egna lådor där de förvarar sitt arbetsmaterial. Runtomkring finns skåp, hyllor och bänkar. De är fyllda med materiel och leksaker såsom papper, pennor, kritor, saxar, lego, spel med mera. Faktaböcker och skönlitterära böcker finns i backar eller på hyllorna. På väggarna sitter alster som barnen har gjort. Längs en av väggarna finns en stor vit whiteboardtavla. På denna sitter veckobrev och annan information uppsatta med magneter. Kort med veckans dagar och månader finns också uppsatta på whiteboardtavlan. Även kort gällande dagens eller veckans frukt- och/eller plingvärd finns här tillsammans med namnet på det barn som har det specifika uppdraget. I närheten av whiteboardtavlan finns en almanacka och skolans matsedel uppsatta. Ovanför whiteboardtavlan eller högst upp längs en av klassrummets andra väggar sitter bilder med alfabetets bokstäver, samt bilder med sifforna ett till nio uppsatta. På en av väggarna finns också en bokstavsplansch med pilar utritade för i vilka steg varje bokstav i alfabetet ska skrivas. Bredvid whiteboardtavlan har läraren sitt skrivbord och där står även en dator, samt ett piano.

Förskoleklasserna har också ett eller två grupprum att tillgå under den tid som verksamheten pågår. Grupprummen är till stora delar utformade på ett likartat sätt. Utmed grupprummens väggar finns mängder av materiel vilka antingen förvaras i skåp eller på hyllor. Här finns exempelvis pennor, papper och spel. Även här hänger alster på väggarna som barnen har gjort. Grupprummen är möblerade med antingen bord och stolar och/eller en soffa. Delar av ett grupprum kan ha sin tydliga profilering mot en viss lek, till exempel en hörna med dockor, dockkläder och dockvagnar. Också i 
grupprummen finns fria golvytor. Även andra rum i skolans lokaler kan användas som grupprum i den mån de är lediga.

\section{Förskoleklassernas aktiviteter}

Gemensamt för lärarna är att de leder olika slags aktiviteter under en arbetsvecka. De aktiviteter som avses i den här studien förekommer under den tid som det på schemat står samling eller gruppmoment. Vid samling eller gruppmoment leder läraren planerade aktiviteter med ett särskilt styrt innehåll. När det är samling närvarar alla barnen i förskoleklassen och vid gruppmoment är klassen delad i två ungefär lika stora grupper. Aktiviteterna förekommer mestadels på samma tid varje dag och är vanligen uppdelade på två till fem pass om dagen. De varar från cirka tio till sextio minuter per gång, men kan variera i tid beroende på vilket innehåll de har eller vad som för övrigt ska hända under dagen. Andra personer än lärarna och barnen kan finnas närvarande under de lärarledda aktiviteterna exempelvis studenter eller föräldrar.

En samling eller ett gruppmoment kan börja med att läraren och barnen först samtalar och sedan gemensamt arbetar med exempelvis en skriftspråklig uppgift. Därefter kan barnen arbeta individuellt med en liknande uppgift. Det förekommer också att ett par eller några av barnen på eget initiativ arbetar tillsammans med uppgiften vilket lärarna ibland uppmuntrar, men de kan även uttrycka "Försök nu jobba själva med uppgiften”. Någon enstaka gång händer det att läraren delar in barnen i mindre grupper, exempelvis när de spelar ett spel med skriftspråkligt innehåll.

När lärarna leder aktiviteterna sitter de bland barnen i en ring på golvet eller så står de strax bakom ringen. De gånger barnen arbetar med egna uppgifter sitter barnen på stolar vid borden eller så sitter eller ligger de på golvet. Lärarna befinner sig då i närheten av barnen.

Hos de tre förskoleklasserna förekommer liknande aktiviteter under en arbetsvecka. Nedan ges en översiktlig presentation av de olika aktiviteter som vanligtvis förekommer under den tid som det på schemat står samling eller gruppmoment.

\section{Morgonsamling med berättarstund}

Morgonsamlingen följer vanligen ett bestämt mönster och har ett innehåll som återkommer varje dag. Morgonsamlingen börjar med att lärarna och barnen tillsammans sjunger eller ramsar en god morgon-hälsning till varandra. Om någon utomstående är på besök får personen presentera sig själv och därefter hälsas den besökande särskilt välkommen. 
Lärarna kontrollerar varje morgon närvaron på olika sätt, exempelvis genom att fråga barnen om de saknar någon kamrat. Ibland får något barn $\mathrm{i}$ uppgift att räkna de barn som är närvarande, men ibland räknar de också alla tillsammans medan läraren pekar på varje barn som sitter i ringen. Därefter kan läraren fråga "Det är 21 barn här idag och vi ska vara 23, hur många fattas då?”

Ett återkommande moment under morgonsamlingen är att uppmärksamma dagens datum, dagens namn och vilken lunch som serveras i matsalen. Oftast brukar ett av barnen få "dra av lappen” från almanackan och berätta vilket datum det är. Barnet berättar då, ibland med stöd av läraren, vilken veckodag, månad och år det är. Sedan upprepar alla detta högt och ibland skriver lärarna också upp datumet på whiteboardtavlan. Samma barn får också läsa dagens namn och dagens lunch, men det förekommer även att en lärare läser detta själv. När dagens namn läses brukar flera barn uttrycka att de känner någon med de aktuella namnen. Ibland får barnen berätta vem personen är och ibland påpekar läraren att det räcker med att barnen tänker på personen ifråga.

För att barnen ska vara förberedda på vad som ska hända under dagen går lärarna igenom schemat varje dag. Oftast skriver en lärare dagens schema på whiteboardtavlan efterhand som hon tillsammans med barnen går igenom det, men det kan också förekomma att schemat finns uppskrivet innan barngruppen samlas och att tidsintervallet för de olika aktiviteterna är angivna. Dessutom kan namnen på de lärare som ansvarar för de olika aktiviteterna finnas uppskrivna. Texten till varje aktivitet brukar få ett tillhörande kort som symboliserar den aktivitet som ska ske under dagen. Korten är handmålade eller så är det fotografier på barn som går i förskoleklassen och som utför den aktuella aktiviteten. Det kan till exempel vara ett kort där barnen sitter i en rund ring på golvet och bredvid kortet skriver läraren samling.

Under morgonsamlingen sker ett byte av dagens eller veckans fruktoch/eller plingvärd. Att vara plingvärd innebär att ett barn får klinga i en liten klocka för att uppmärksamma kamraterna på att en aktivitet är slut. Vanligtvis får det barn som haft uppdraget dra en namnlapp ur en burk och själv eller tillsammans med läraren läsa namnet på den person som ska få ta över uppdraget.

Ett dagligt moment är också att lärarna och barnen har berättarstund. Då samtalar de om ämnen och händelser som är nära förknippade med barnens vardag och intressen. Samtalen kan till exempel handla om vad barnen ska göra eller har gjort i helgen eller hur de tog sig till skolan. Det kan även handla om de fritidsaktiviteter som barnen sysslar med. Det förekommer att barnen tar med sig saker hemifrån som de vill berätta om och visa upp för sina kamrater och lärare. Det kan exempelvis vara något som de har fått i present eller visa ett kort på ett nytt syskon. 
Under morgonsamlingen diskuteras även problem som kan finnas i förskoleklassen till exempel om barnen är oense om något. Under morgonsamlingen får barnen dessutom information om sådant som direkt berör klassen eller skolan.

\section{Skriftspråkliga aktiviteter}

När lärarna och barnen arbetar med skriftspråket utgår lärarna ibland från läromedlen Trulle eller Bornholmsmodellen. Enligt författarna till läromedlen syftar Trulle och Bornholmsmodellen till att träna den språkliga medvetenheten genom att barnen får leka med språket (Bryntse \& Palmkvist, 1996; Lundberg, 2007). Övningarna i läromedlen innehåller moment som att arbeta med exempelvis sammansatta ord och att lyssna efter ljud i ord. Till materialet Trulle hör dockorna Trulle och Trulsa vilka följer barnen genom de olika övningarna. Vid dessa tillfällen har lärarna ibland lärarhandboken till något av läromedlen bredvid sig och tar emellanåt stöd i den under tiden som aktiviteten pågår. Vid andra tillfällen används inte några färdigproducerade läromedel som underlag, exempelvis när svåra ord behöver förklaras eller när de arbetar med rimövningar. De skriftspråkliga aktiviteterna innehåller också inslag av skrivande där barnen får öva på att använda alfabetets bokstäver. Barnen skriver då ord och meningar, ofta utifrån ett av läraren angivet ämne.

Högläsning av berättelser förekommer genom att läraren, men ibland också barnen, läser högt. När läraren högläser kan barnen samtidigt äta frukt, vilket inte sker när något barn läser. Det är läraren som väljer vilken bok hon eller barnen ska läsa. Ibland berättar läraren varför hon valt en viss bok, till exempel att en bibliotekarie rekommenderat den. När barnen högläser berättelser som de haft i läxa, bestämmer däremot varje barn tillsammans med läraren vilken berättelse hon eller han ska läsa.

När läraren högläser läser hon antingen en hel berättelse vid ett högläsningstillfälle eller så läser hon ett avsnitt ur en berättelse och då tar det några tillfällen innan hela berättelsen är färdigläst. Barnen i sin tur läser alltid klart sin berättelse vid ett högläsningstillfälle.

\section{Matematikaktiviteter}

Under matematikaktiviteterna arbetar lärarna och barnen med olika matematikområden såsom problemlösning och diskussion av matematiska begrepp. Lärarna kan ha satt samman en mindre bok som innehåller arbetsblad med övningar från olika matematiska områden. Alla barnen har då en egen bok och arbetar med den i sin egen takt under den tid som aktiviteten pågår. 


\section{Skapande aktiviteter}

Barnen målar/ritar bilder eller pysslar ofta under den tid som de har skapande aktiviteter. När barnen ritar utgår motiven vanligtvis från det som händer eller har hänt nära barnen. Förskoleklassen kan till exempel ha varit i skogen och barnen får rita en egen bild från utflykten. Det som barnen ritar sätts vanligen upp i klassrummet, grupprummet eller i kapprummet.

Att öva på att klippa ut motiv med sax, göra figurer med hjälp av lera eller göra pyssel där barnen får öva på att sy är också vanliga aktiviteter.

\section{Slutsamling}

Dagen i förskoleklass avslutas med en kort slutsamling då läraren och barnen samlas i en ring på golvet. Läraren prickar av vilka barn som ska gå hem och vilka barn som ska gå till fritidshemmet. Om det är något som barnen särskilt behöver komma ihåg brukar läraren påminna om det. Det kan till exempel handla om att de ska visa veckobrevet för föräldrarna eller att de ska ta med kläder till morgondagens idrottslektion. Slutsamlingen avslutas vanligen med att man sjunger en "hejdå-sång” tillsammans. 


\section{Samtalet}

Detta kapitel handlar om mötet mellan läraren och barnen under lärarledda samtal. Det är hur läraren och barnen i interaktion med varandra handlar och hur det skapar möjligheter och begränsningar för barnen att delta i samtalet som är i fokus. Samtalen förekommer på schemat under benämningarna samling och gruppmoment. Vid dessa tillfällen leder läraren samtal där aktiviteterna har olika innehåll, som exempelvis högläsning av berättelser eller diskussion av matematiska begrepp. Samtalen har således olika innehåll beroende på vilken aktivitet det handlar om. Hur läraren organiserar och strukturerar barnens deltagande i samtalet går dock till på ett likartat sätt oavsett vilken aktivitet som är i fokus.

Kapitlet handlar även om lärarhandlingar som i mötet med barnen framstår som inkonsekventa. Lärarens olika sätt att kommunicera och interagera blir då motsägelsefullt för barnen men som barnen på olika sätt ändå måste förhålla sig till.

\section{Samtalets möjligheter och begränsningar}

I följande avsnitt är det samtalets möjligheter och begränsningar som står i fokus. I analysen av det empiriska materialet har tre underteman identifierats: (a) frågebank (b) turordning och (c) handuppräckning.

I undertemana frågebank, turordning och handuppräckning pågår ett arbete med språkets funktion, det vill säga hur deltagarna använder språket i olika sammanhang. Det handlar till exempel om hur läraren och barnen samspelar om talutrymmet, hur de använder sitt kroppsspråk och valet av det ämne de samtalar om.

\section{Frågebank}

När läraren initierar ett samtal använder läraren sig oftast av öppna frågor. En öppen fråga kan inledas med frågeord som vad, hur eller varför, exempelvis "Vad tror ni att boken handlar om", "Hur kom du till skolan idag?” eller "Varför går man i förskoleklass?”. En del av frågorna vet läraren redan svaren på, men inte på andra. Läraren ställer frågorna antingen till alla närvarande barn eller till ett specifikt barn i gruppen. Någon gång händer det att barnen får bestämma samtalsämne. Läraren kan exempelvis fråga "Är det någon som har något att berätta idag?”. Det är framför allt under en del av morgonsamlingen som barnen bestämmer 
samtalsämne. Lärarens frågor utgår emellertid vanligtvis ifrån ett samtalsämne som hon själv har valt.

Exempel 6:1 Hur är vädret?

Läraren: $\quad$ Undrar vad jag kan säga om vädret idag?

Många händer kommer i luften, men ingen säger något högt. Ulla ger först ordet till Johanna och fördelar sedan ordet vartefter händerna räcks upp, antingen genom att säga barnets namn, peka på eller ta ögonkontakt med barnet.

Johanna: Snö

Sara: $\quad$ Kyla och kallt

Läraren: Ja, idag var det bara minus fem grader. Igår var det 15 minus när vi skulle åka och spela handboll. Var det ljust eller mörkt när ni gick hit idag?

Flicka: $\quad$ Ljust

(Observation, 2012-12-10)

Ulla ställer en fråga om dagens väder och många barn räcker upp handen. Svaret från ett av barnen utmynnar i att Ulla svarar med ett eget inlägg. Därefter ställer Ulla en fråga med två svarsalternativ. Frågan om vädret engagerar barnen att delta i samtalet. Frågan inbjuder också barnen till att besvara den på olika sätt och med det får barnen mer möjligheter till att delta i samtalet. När läraren följer upp ett barns svar gör hon det genom att utveckla svaret själv, vilket visar på ett turtagande utifrån IRF-strukturen. Läraren initierar till samtal genom att ställa en fråga. Ett barn svarar på frågan och läraren följer upp svaret genom att vidareutveckla svaret själv. Situationen avslutas med en sluten fråga som stänger samtalet.

När läraren ställer en fråga har en del barn mycket att berätta och använder en större del av det gemensamma talutrymmet. Läraren kan då stoppa samtalet och istället ge ordet till ett annat barn eller byta samtalsämne och på så sätt gå vidare.

I nedanstående sekvens har morgonsamlingen precis börjat och läraren Helene ber Emilie sätta sig i den för dagen framtagna guldstolen istället för att sätta sig på sin plats i ringen. När Emelie sätter sig ner på stolen ler hon. Helene säger att Emilie ska få berätta om sin födelsedagsmorgon, men först ska de sjunga "god morgon-sången" och kontrollera vilka av barnen som inte är där idag. När detta är gjort tänder Helene några värmeljus som står på en liten pall framför Emilie. Det sjätte ljuset vill inte ta sig och Helene småskrattar. 
Läraren: Ja, du får låtsas att det är sex. Det verkar som att stearinet är slut. Hur var din morgon Emilie?

Emilie berättar fort och livligt om föräldrarnas födelsedagssång medan hon låg kvar i sängen. Hon berättar att hennes bästa present var en cykel och säger med en något högre röst att det var en stor cykel. Hon berättar också att hon cyklade med den till skolan. Emelie ler och är på väg att berätta något mer, men hennes första ord försvinner bort [tittar på Helene med uppspärrade ögon] eftersom Helene i samma stund säger:

Läraren: Vad har hänt sedan förra veckan?

Vi har gått in i en ny månad

(Observation, 2012-09-03)

Det är Emiles födelsedag och Helene har ställt fram en stol och tänt ljus. Emilie berättar en längre stund entusiastiskt om sin födelsedagsmorgon. När Helene avbryter berättandet och går vidare med ett nytt innehåll blir Emilie förvånad och tystnar. Den öppna frågan som läraren först ställer gör det möjligt för Emelie att berätta om sin present och dela med sig av sin upplevelse till kamraterna och läraren. Emilies glada ansikte och entusiastiska sätt att berätta visar att hon gärna vill berätta om vad hon har varit med om under morgonen. När läraren sedan avbryter berättandet genom att ställa en fråga till hela gruppen tystnar Emelie. Lärarens handlingar begränsar således Emelies talutrymme och möjlighet till fortsatt deltagande i samtalet. I den efterföljande frågan integrerar läraren inte heller Emelies svar. Hon tar därmed inte vara på innehållet i det som Emelie berättar för att fördjupa samtalet utan väljer istället att byta samtalsämne.

Det finns även barn som inte uttrycker sig så mångordigt utan berättar med några enstaka ord eller inte alls vill prata inför gruppen. Läraren låter det vara så eller så ställer hon frågor som hjälper barnet att komma på något att säga. En del av de följdfrågor läraren ställer vet hon redan svaret på medan andra frågor är mer öppet hållna.

Exempel 6:3 Följdfrågor som utvecklar det berättade

Peter: $\quad$ Nästa vecka ska jag och mamma och pappa åka till Lyckan och åka pulka

Läraren: $\quad$ Ska ni till den stora backen då?

Peter: Ja

Läraren: Noel

Noel: $\quad$ Igår åkte jag skridskor

Läraren: Var någonstans?

Noel: $\quad$ I lekparken 
Läraren: Var är du då?

Noel: $\quad$ Skogsviken

Läraren: $\quad$ Gick det bra att åka skridskor då?

Noel: $\quad$ Ja

Flicka: Igår skulle vi göra pepparkakshus. Det var som krossat godis som vi satte ihop. Det var kul.

Läraren: Det tror jag det

Sedan berättar flera barn att också de gjort pepparkakshus i helgen. Efter en stund undrar Noel om de inte ska dra dagens plingvärd istället för att prata om helgen. Ulla menar att de ska göra det strax, men att det verkar som att det finns fler barn som har saker att berätta då några sitter med handen uppe. Ulla låter sedan alla barn som har handen uppe berätta det de vill.

(Observation, 2012-12-10)

Ulla följer upp barnens svar med följdfrågor vilka de besvarar kortfattat. När ett barn berättar om en händelse från helgen svarar Ulla genom att hålla med barnet. Därpå följer andra barn efter och berättar om liknande erfarenheter. Ett barn vill gå vidare, men Ulla håller fast vid att alla som räcker upp handen ska få svara först. De följdfrågor läraren ställer ger barnen en möjlighet att utveckla sina svar, men dessa kräver inte några längre och fördjupande sådana utan barnen svarar på en fråga med ett fåtal ord. Följdfrågorna är på så sätt oftast utformade som ledande frågor till barnen. Lärarens följdfrågor kan dock ses som en ingång och en början till ett dialogiskt klassrum, men detta bryts efter några samtalsturer då läraren istället ger ordet till nästa barn. Eftersom läraren låter de barn som vill komma till tals kan antalet barn som vill svara sätta begränsningar för hur många frågor hon kan ställa till varje barn, men även vilken karaktär frågorna kan ha. När läraren följer upp Noels svar gör hon det genom att ställa en ny fråga till honom, vilket visar på ett turtagande utifrån IRFstrukturen. Genom att läraren håller med om det som ett barn säger bekräftar läraren barnets svar genom att värdera det. Då ett barn berättar om en händelse från helgen inspirerar det flera barn att berätta om liknande erfarenheter. Ett barns inlägg kan på så sätt vägleda andra barns berättande. När läraren och ett barn samtalar turas de om att ha ordet vilket ger barnet möjlighet att träna på samtalets turtagning. Under tiden som läraren och ett barn samtalar kan övriga deltagare lyssna till det som sägs och genom det få möjlighet att träna sin förmåga att lyssna. För att kunna svara på lärarens frågor behöver även det barn som har ordet lyssna till vad läraren frågar om. När barnen ger sannolika svar på lärarens frågor eller räcker upp handen är tillfällen då barnen troligtvis intar en position i samtalet som lyssnare. Noels önskan om att byta moment kan vara ett uttryck för att han inte orkar lyssna mer eller för att han tappat intresset och vill göra något annat istället. 
De följdfrågor som läraren ställer så att barnen kan tänka vidare och utveckla sina svar kan ses som stödstruktur för att samtalet ska utvecklas. Genom lärarens följdfrågor får barnet möjlighet att berätta mera om en händelse och därigenom får barnet fler möjligheter att utveckla sin språkliga förmåga. Däremot är tekniker som skulle ge möjlighet till en fördjupning av samtalet frånvarande här.

När läraren och ett barn samtalar med varandra kan de barn som inte deltar i samtalet stundtals viska eller prata med varandra. De kan också ha svårt att sitta still eller att sitta kvar på sina platser. När läraren och barnen sitter vända mot varandra i en ring på golvet vänder de exempelvis ryggen mot den gemensamma sittningen, drar sig utanför ringen, lägger sig på ryggen eller magen eller börjar plocka med någon leksak. Läraren säger då ”Sätt er ordentligt i ringen” eller "Jag vet att det är jobbigt att lyssna, men för det måste man sitta upp”. Om barnen leker med någon leksak uppmanas de att plocka undan leksaken. Ibland får de visa upp leksaken för de andra barnen innan den tas bort. Det förekommer att barnen genast gör som läraren ber dem, men ibland gör de inte det och läraren upprepar sitt önskemål. Barnen kan då protestera muntligt eller demonstrativt överdriva sina rörelser när de till exempel sätter sig upp igen. När ett barn börjar "skruva på sig”, följer vanligen också fler efter. Det finns barn som gör någon eller flera av handlingarna och samtidigt lyssnar till vad som sägs och när de får en fråga från läraren svarar de med vad som kan förväntas. Det förekommer också att barn sannolikt inte lyssnat på det samtal som försiggått då de inte kan berätta vad som nyss sagts när läraren ber dem redogöra för det.

Det är fredagsmorgon och Evy och barnen pratar om vad barnen ska göra i helgen. Under tiden som några av barnen berättat har Anton sakta dragit sig undan sin plats i ringen. Han sitter nu lite utanför ringen med ansiktet vänt mot ett bordsben och trummar sina fingrar emot benet. Evy vänder sig mot Anton och ber honom sätta sig i ringen igen.

Exempel 6:4 Vad har du för planer för helgen?

Anton hasar sig sakta tillbaka till ringen utan att titta på Evy.

Läraren: $\quad$ Vad har du för planer då?

Anton: Träffa kusinerna [tyst och surt]

Läraren: Jamen, det låter ju kul!

(Observation, 2013-04-12)

Anton återvänder långsamt till sin plats utan att möta Evys blick. Evy frågar om hans planer för helgen vilket han svarar kort och undfallande på. Evy ger därefter en positiv återkoppling på hans svar. Genom sitt avvisande kroppsspråk där Anton drar sig undan den gemensamma sittningen, 
trummar fingrarna mot ett bordsben, långsamt återvänder till sin plats utan att titta på läraren, samt svarar med ett missnöjt tonfall, verkar det som att samtalsämnet inte intresserar Anton särskilt mycket. Antons sätt att handla kan vara ett uttryck för att han gör motstånd mot det pågående samtalet. Då läraren följer upp Antons svar genom att berätta vad hon tycker om det som han berättar om ger hon ett svar som positivt värderar Antons inlägg. Turtagandet mellan läraren och barnet utgår därmed från IRE-strukturen. Läraren initierar till samtal genom att ställa en fråga till Anton. Han svarar på frågan och läraren följer upp svaret genom att värdera det svar Anton ger.

Det finns också barn som till synes verkar lyssna uppmärksamt på det samtal som försiggår genom att de med blicken följer den som har ordet. Ibland skrattar barnen även med när andra skrattar eller upprepar någon kamrats kommentar. När barnen själva får ordet följer de emellertid inte samtalstråden, utan börjar prata om något som inte kan knytas till det pågående samtalet.

I nedanstående sekvens har Ulla och barnen morgonsamling. De pratar om vad som hände i gårdagens avsnitt av julkalendern på TV. Barnen ger en snabb resumé av handlingen och då och då inflikar Ulla med en fråga. Ibland berättar något barn samma sak som någon tidigare berättat, men ingen kommenterar det utan alla sitter tysta och vänder sig mot den som för tillfället har ordet. Wojcek vill ha ordet och Ulla nickar åt honom.

\section{Exempel 6:5 Vad hände i julkalendern?}

Wojcek berättar om ett kalas han varit på, vad flickan hette som hade kalaset och att hans familj köpte en present till henne. När Wojcek börjar prata höjer Ulla på ögonbrynen och hennes ögon spärras upp något. Under tiden som han berättar ställer Ulla ett par frågor till det som han berättar om. När han pratat klart frågar Ulla om hon förstått det hela rätt med att det är ett kalas han varit på och att de köpt en present till flickan som fyllde år. Wojcek nickar och därefter pekar Ulla på ett annat barn som fortsätter prata om julkalendern.

(Observation, 2012-12-11)

Wojcek byter samtalsämne och berättar om ett födelsedagskalas han varit på. Ulla reagerar förvånat på det som Wojcek berättar, men hon lyssnar, ställer frågor, repeterar det han sagt och undrar om det var så han menade. Därefter ger Ulla ordet till ett annat barn som återgår till att tala om julkalendern. Lärarens reaktion på det som Wojcek berättar handlar sannolikt om att hon förväntade sig att han skulle fortsätta prata om julkalendern. Wojcek verkar lyssna på det samtal som försiggår, men när han får ordet fortsätter han inte på det ämne de talar om utan initierar ett 
nytt. Möjligen bottnar ett ämnesbyte i en bristande förståelse för vad samtalet handlar om eller så har Wojcek tröttnat på ämnet och därför väljer att tala om någonting annat. Det kan också vara så att han utifrån samtalet om julkalendern kommit på något som han vill berätta om. När läraren repeterar det som Wojcek berättat och undrar om hon har uppfattat honom rätt ger hon Wojcek möjlighet att förtydliga det som han har berättat. Genom att läraren repeterar det som Wojcek berättat och att han också bekräftar att läraren uppfattat honom rätt, kan en gemensam tolkning uppstå. Läraren använder därmed samtalshandlingen "revoicing" för att skapa förståelse för vad Wojcek berättat. Läraren väljer sedan att inte ställa frågor på det innehåll Wojcek talat om och som skulle kunnat leda till en dialog med fler barn inblandade i det som intresserat honom. Istället återgick hon till det ursprungliga samtalsämnet.

I samtalet mellan läraren och Wojcek kan språket ses som ett medierande redskap som skapar möjligheter för en gemensam tolkning av det berättade.

\section{Turordning}

Läraren låter ofta varje barn som är närvarande komma till tals i samtalet. För att ge alla barnen möjlighet att uttrycka sig lägger läraren en hög med kort framför sig med namnen på barnen i gruppen. Läraren drar slumpmässigt ett kort ur högen och det namn som står på kortet blir också den som får börja prata till gruppen. När alla kort är dragna har alla barnen haft ordet. Ett annat sätt är att läraren "går laget runt” och på så sätt får alla barn komma till tals. Om hela klassen är närvarande sitter barnen i en ring på golvet tillsammans med läraren. Det förekommer också att läraren står strax bakom ringen. Läraren ger ordet till ett barn i taget i den ordning som de sitter. När klassen är uppdelad i två grupper sitter barnen i en halvcirkel framför läraren som antingen sitter eller står upp. Även här får barnen ordet i den ordning de sitter i halvcirkeln. Läraren ger ordet till barnen genom att säga deras namn alternativt peka eller nicka med huvudet mot det barn som står i tur att prata. Om ett barn påkallar lärarens uppmärksamhet och vill ha ordet tidigare än vid sin tur brukar läraren hålla fast vid den bestämda turordningen. Läraren svarar då "Vänta, det blir snart din tur”, men det förekommer också att läraren låter barnet berätta det som hon eller han vill. Samma barn kan senare få ordet igen när denne står på tur.

Exempel 6:6 I vilken ordning ska vi berätta?

Läraren: Ska vi ta helgen först eller plingvärden? Klara vad tycker du?

Klara: $\quad$ Helgen först [flera av barnen instämmer]

Läraren: Var ska vi börja då? 
Klara: $\quad$ Här [pekar på Sara som sitter bredvid Ulla]

Läraren: Vilket håll ska vi gå då?

Klara: $\quad$ Så [pekar på Sara och sedan med fingret i vänstervarv]

Läraren: Sara, vad har du gjort i helgen?

Sara: $\quad$ Åkt pulka och varit på Stinas kalas. Vi pysslade.

(Observation, 2012-12-10)

Ulla låter Klara avgöra vem av barnen som ska få delge sin berättelse först samt i vilken turordning de andra barnen ska få ge sin. Med hjälp av sitt kroppsspråk svarar Klara på detta. I den här situationen gör läraren därmed ett barn delaktigt i avgöranden kring turordningen. Barnen deltar i samtalet när det blir deras tur och får välja en händelse ur minnet som de sedan beskriver muntligt. Eftersom barnens deltagande i samtalet är beroende av var turordningen börjar får de vänta olika länge på att komma in i samtalet och med det kan ett barn få lyssna till många kamrater innan det själv får ordet eller motsatsen, tidigt få ordet och sedan "endast” lyssna till det som kamraterna har att säga. Det finns barn som då tappar orken och istället gör annat såsom att viska med varandra. Turordningen kan på så sätt skapa en lyssnarposition där barn gör annat än att lyssna på den person som har ordet. Barnen får genom turordningen också olika lång tid på sig att välja ut det som de vill prata om. I avsnittet om Frågebank framkom att en del barn uttrycker sig mångordigt när det är deras tur att prata inför gruppen, medan andra barn är fåordiga. Läraren avgränsar också samtalet eller ställer stödjande följdfrågor beroende på hur mycket barnet pratar. Därigenom begränsas talutrymmet för de barn som pratar mycket medan mer utförliga svar efterfrågas från de barn som inte säger så mycket. Läraren ordnar således för att samtliga barn blir delaktiga i samtalet och att de får ungefär lika stort talutrymme. Därigenom kan barnens deltagande i samtalet beskrivas som "rättvist" fördelat i meningen att alla får komma till tals, medan möjligheten till ett mer fördjupat samtal tenderar att begränsas. Genom att läraren använder sig av en turordning där samtliga barn har möjlighet att komma till tals kan läraren också på ett enkelt sätt få överblick över vilka barn som är delaktiga i samtalet.

Kroppsspråk, i form av pekningar, vilket Klara använder sig av för att svara på lärarens fråga om turordning, kan ses som en medierande resurs som möjliggör för Klara att svara på frågan. Klara uppmuntras emellertid inte att utveckla sina kortfattade svar och uttrycka sig i hela meningar, vilket innebär att en möjlighet till språkutvecklande dialog begränsas.

\section{Handuppräckning}

I klassrummet finns olika förhållningsregler uppsatta både i skrift och i bild. En regel gäller hur barnen ska agera när de vill berätta något för gruppen och uttrycks som "I detta klassrum räcker vi upp handen när vi vill säga 
något”. Läraren har antingen själv bestämt regeln eller så har läraren och barnen samtalat med varandra och gjort en överenskommelse om hur kommunikationen mellan dem ska ske. I praktiken används regeln när läraren ställer frågor och barnen visar med sitt kroppsspråk att de vill svara. De räcker då upp handen och håller den stilla i luften, men det händer även att de viftar med den, tittar intensivt på läraren och säger hennes namn eller ”Jag kan”, ”Jag vill”. Läraren behöver heller inte alltid ha ställt någon fråga till gruppen för att barnen ska visa att de vill berätta något. Efter att barnen själva visat att de vill delta i samtalet ger läraren barnen ordet genom att säga deras namn, peka på, ta ögonkontakt eller nicka åt dem. Det finns barn som visar att de vill svara på lärarens frågor flera gånger under en lärarledd aktivitet, andra visar någon gång att de vill det, medan andra inte alls räcker upp handen. Här är det vanligen samma barn som agerar på liknande sätt oberoende av vilket innehåll samtalet har.

\section{Exempel 6:7 Räck upp handen}

Sången om årets månader klingar bort.

Läraren: Räck upp handen nu om du vill säga något om Trulles utflykt

Många händer kommer i luften och Helene tittar och nickar åt flickan som sitter bredvid henne.

(Observation, 2013-04-15)

Helene ber barnen att räcka upp handen så att hon ser vilka barn som vill delta i samtalet och berätta om Trulles utflykt. Det är genom att räcka upp handen som barnen på eget initiativ visar för läraren om och när de vill prata, men det är vanligen läraren som väljer och därmed styr vilka av barnen som får delta i samtalet.

I exemplet ovan börjar läraren aktiviteten med att påminna barnen om regeln att räcka upp handen när de vill berätta något för gruppen. Det förekommer också att läraren ett flertal gånger påminner barnen om att de ska räcka upp handen om de vill säga något under tiden som en aktivitet pågår. Vid dessa tillfällen händer det att hon höjer rösten och tittar bestämt på var och en av dem. Ibland säger läraren barnens namn och talar direkt till dem som det berör. Ibland påminner läraren också om de förhållningsregler som finns uppsatta på väggen i klassrummet. Hon pekar tyst på reglerna eller säger att barnen ska tänka på vad som står skrivet och ritat där. Efter att läraren bett barnen räcka upp handen kan hon också indirekt tala om att barnen ska räcka upp handen genom att säga att de inte får prata rakt ut. För några barn är det tillräckligt att läraren säger till en 
gång för att de fortsättningsvis ska räcka upp handen när de vill berätta något eller svara på en fråga, medan det för andra krävs upprepade tillsägelser. Vanligen är det samma barn som inte räcker upp handen när de vill ha ordet utan pratar eller svarar på en fråga från läraren utan att läraren ber om det. Detta sker främst vid aktiviteter där barnet på något sätt förväntas visa vilken kunskap hon eller han har om ett ämne. Somliga barn kan följa efter och svara utan att räcka upp handen, medan andra sitter tysta.

I nedanstående sekvens ska Mona och barnen i förskoleklassen precis börja en matematikaktivitet. De sitter i en ring på golvet. Mitt på golvet ligger en mängd olika föremål utspridda. Det finns tre av varje föremål. Flera av barnen har tidigare frågat Mona om varför föremålen ligger där. Mona har svarat barnen med att konstatera att föremålen finns där.

\section{Exempel 6:8 Vi pratar inte rakt ut}

Läraren: Då så, då ska vi se vad vi har på golvet, ni hade lite bekymmer kring det, vad är det?

Många händer kommer i luften. Några av barnen berättar också vad de ser samtidigt som de räcker upp handen eller utan att räcka upp handen.

Läraren: Räck upp handen utan att säga något. Ludvig? [räcker upp handen]

Ludvig: $\quad$ Pengar

Mona tilltalar efterhand de barn som sitter med handen i luften.

Läraren: Ja, Alice?

Alice: $\quad$ Gem

Läraren: Bra. Isabelle?

Isabelle: Tärningar och kulor

Några av barnen småpratar eller viskar med varandra och Mona säger:

Läraren: Sschh! Vad säger du Eric?

Eric: $\quad$ Stenar och pengar

Läraren: Ni andra som inte fått ordet ska vara tysta, vad säger du Elias?

Elias: $\quad$ Ploppar

Läraren: Ja, bra. Vi har fler saker, ser ni? Nä, nu pratar vi inte rakt ut (Observation, 2012-10-01)

Mona korrigerar icke önskvärda beteenden och instruerar barnen hur de istället ska agera för att få ordet, det vill säga att de ska visa med handen att de vill svara. Därefter ger hon ordet till de barn som räcker upp handen. Mona besvarar barnens inlägg med att evaluera deras svar. När läraren korrigerar barnens beteenden går tid från innehållet i samtalet. Då läraren korrigerar barnens beteenden uttrycker hon muntligt sitt missnöje med deras sätt att agera. Läraren ger ordet till de barn som räcker upp handen, 
och belönar därigenom det beteende som hon tidigare uttryckt att barnen ska agera efter om de vill svara på hennes fråga. När läraren återkopplar på barnens inlägg genom att berätta vad hon tycker om svaren bekräftar hon positivt deras svar. Genom att läraren uttrycker "Vi har fler saker, ser ni?” gör hon barnen uppmärksamma på innehållet i uppgiften. Inlägget ger även en antydan om att fler barn har möjlighet att delta i samtalet.

När barnen inte räcker upp handen då de vill svara på en fråga utan istället pratar rakt ut kan läraren titta bestämt på varje barn eller peka på de förhållningsregler som finns uppsatta på väggen i klassrummet. Läraren visar på så sätt även sitt missnöje med barnens agerande med hjälp av kroppsspråket. Lärarens muntliga utsagor och hennes kroppsspråk blir därmed verktyg för korrigeringen. Genom att läraren inleder en aktivitet med att tala om hur hon vill att barnen ska agera och sedan korrigerar beteenden som inte är önskvärda, impliceras ett elevbeteende i klassrummet där barnen förväntas agera på ett visst sätt för att få ordet.

Förväntningarna på barnen att de ska handla på ett visst sätt för att få ordet kan få sin förklaring av att handlingarna förekommer i skolans praktik. Lärarens muntliga utsagor och hennes kroppsspråk ger barnen signaler om hur barnen ska bete sig när de är i skolan.

\section{Samtalets komplexitet}

I följande avsnitt är det samtalets komplexitet som står i fokus. I analysen av det empiriska materialet har två underteman identifierats: (a) barnet tar initiativ till att delta i samtalet och (b) läraren tar initiativ till samtal med barnen.

\section{Barnet tar initiativ till att delta i samtalet}

När läraren och ett barn har en dialog med varandra förekommer att ytterligare ett barn vill komma in i samtalet utan att läraren gett det barnet ordet. Emellanåt tillåter läraren detta och låter även detta barn fortsätta prata, men vanligen förklarar hon hur hon vill att barnet ska agera istället. Det kan ske efter det att barnet pratat klart. "Roligt att höra, men räck upp handen nästa gång" eller "Helt rätt, men räck upp handen innan du svarar”, är kommentarer som läraren ger. Det händer också att läraren direkt hejdar barnet antingen genom att muntligt tala om att barnet måste räcka upp handen eller så sätter läraren upp sin hand i luften, vilket gör att barnet tystnar. Efter detta kan barnet räcka upp handen och därpå få ordet av läraren eller så får barnet ordet vid ett senare tillfälle eller inte alls. Det finns barn som aldrig säger något utan att läraren ber dem, medan andra barn pratar i varierande grad. Under en lärarledd aktivitet får även ett barn 
komma till tals vid flera tillfällen fast läraren uttalat att barnet inte kommer att få ordet.

I nedanstående sekvens har Ella och barnen i förskoleklassen morgonsamling. De har pratat om vilken årstid det är och dagens datum och Victor har fått svara på en av Ellas frågor. Victor har också blivit uppmanad att vara tyst när han och några kamrater viskat med varandra. De har nu övergått till att prata om dagens schema och Ella visar en bild på varje aktivitet varvid barnen får svara på vilken aktivitet bilden föreställer. Ella skriver namnet på aktiviteterna på whiteboardtavlan efterhand och sätter sedan upp den tillhörande bilden bredvid. Många av barnen vill vara med och svara vilket de visar genom att räcka upp handen. När Ella vänder sig om efter att ha skrivit samling på tavlan tittar hon på Victor och säger med irritation i rösten:

\section{Exempel 6:9 Du har pratat färdigt nu}

Läraren: Du kan ta ner handen Victor, du får inte prata ändå

Ella vänder sig om mot tavlan och skriver "träffa?” på nästa rad samtidigt som hon säger "träffa” högt. Hon vänder sig om mot barnen

Läraren: Vadå?

Många av barnen räcker upp handen och Victor håller kvar sin i luften.

Läraren: Okej, Victor

Victor: Träffa våra faddrar

Läraren: Just det. Och ni som vet vad som ska hända då får vara lite tysta om det. Det blir lite roligare då för de som inte vet

Tillsammans går de igenom resten av dagens schema och när de kommer till den sista punkten, luciatåget, pratar de om vilka personer som ingår i ett sådant tåg, vilka som får lov att komma och titta på luciatåget och hur några av barnens luciatåg gick till på förskolan. Under tiden som samtalet pågår sprider sig mummel och småprat i rummet. Ella uppmanar dem att vara tysta och lyssna samtidigt som Victor flera gånger säger ”Ella”.

Läraren: Det räcker nu! Du har pratat färdigt nu

Victor tystnar.

(Observation, 2012-11-27)

Ella avvisar Victors önskan om att komma in i samtalet, men han fortsätter att visa med handen att han vill delta och Ella låter honom prata. Efter att Victor ytterligare en gång muntligt påkallat Ellas uppmärksamhet, upprepar Ella sitt avvisande om att inte låta Victor delta i samtalet varpå Victor tystnar. Lärarens första avvisande av Victors önskan om att delta i samtalet 
accepteras inte av Victor och läraren ger sitt samtycke genom att säga hans namn. Läraren nekar således först Victor att delta i samtalet, men strax därpå ger hon honom ordet vilket får hennes handlingar att framstå som motstridiga för Victor och de andra barnen. Då Victor inte accepterar att han inte får delta i samtalet utan håller kvar sin hand i luften ger läraren honom ordet och på så sätt får Victor mer talutrymme. När Victor återigen vill delta i samtalet avvisar läraren honom ytterligare en gång och han accepterar genom att tystna. Läraren visar på så sätt sitt missnöje med Victors agerande muntligt. Att inte acceptera att man inte får delta $\mathrm{i}$ samtalet och då utmana systemet genom att fortsätta räcka upp handen kan således göra att man får ordet av läraren. Att en gång lyckas bryta mot systemet kan också var skäl till att barnet försöker igen. Läraren kan också hejda ett barn från att delta i samtalet genom att sätta upp sin hand i luften. Läraren visar på så sätt även sitt missnöje med ett barns agerande med hjälp av kroppsspråket. Både muntligt språk och kroppsspråk blir i och med det verktyg för korrigeringen.

\section{Läraren tar initiativ till samtal med barnen}

Läraren ställer ibland en fråga till gruppen utan att i förväg förklara hur barnen ska agera för att få ordet. De barn som vill svara visar det genom att räcka upp handen. En fråga till gruppen kan också medföra att något eller några barn svarar i kör och "rakt ut". Ibland tillåter läraren detta utan någon kommentar, vid andra tillfällen påpekar hon hur hon vill att barnen ska agera istället, det vill säga med handuppräckning. Det händer också att läraren efter det att hon har ställt en fråga och barnen svarat "rakt ut”, säger ett barns namn och ber denne om ett svar. Det förekommer även att läraren överger sitt beslut om att barnen ska räcka upp handen under den pågående aktiviteten, vilket nedanstående sekvens är ett exempel på.

Vi återupptar mötet med Mona och barnen från exempel 6:8. Ett antal av de föremål som ligger på golvet är nu benämnda, men fortfarande finns några osagda. Mona inledde aktiviteten med att hon ville att barnen skulle räcka upp handen om de ville ha ordet, men har efterhand delvis frångått detta. Ändringen är inget som hon informerat barnen om.

\section{Exempel 6:10 Att få ordet utan att ha bett om det}

Läraren: Hm, Isa [räcker upp handen]. Vad har du hittat?

Isa: $\quad$ Tre av ringarna

Läraren: Hm, tre av ringarna. Lucas?

Lucas: Jag räckte inte ens upp handen!

Läraren: Ja, men det har inte andra gjort heller, men nu frågar jag dig

Lucas: Kulorna

(Observation, 2012-10-01) 
Mona fördelar ömsom ordet mellan de barn som räcker upp handen och de barn som hon vill ska svara på frågorna. Det svar som Isa ger upprepas av Mona innan hon ber Lucas om ett svar. Lucas avvisar Mona med förklaringen att han inte signalerat att han vill svara. Mona förklarar i sin tur att hon låtit andra barn svara utan att de själva visat att de så vill och håller fast vid att Lucas behöver ge ett svar, vilket han då gör. Läraren återkopplar på ett elevsvar genom att upprepa det som barnet sagt vilket kan göra att alla barnen i klassen uppmärksammar svaret en gång till. När läraren delvis frångår regeln att barnen ska räcka upp handen om de vill svara, vilket hon påtalat i början av aktiviteten, och även låter barn delta $\mathrm{i}$ samtalet som inte själva visat att de vill det och utan att tala om att det kan förekomma, framstår handlingarna som motstridiga. Lärarens handlingar kan på så sätt bli motsägelsefulla för barnen. Barnets deltagande i samtalet bygger på ett slags "här och nu" initiativ från läraren och ett barn kan därmed tilldelas ordet utan att man visat att man vill ha det. När barnet tilldelas ordet av läraren kan barnets motstånd till att delta i samtalet vara ett uttryck för att barnet förhåller sig till just det som läraren först sagt, det vill säga att räcka upp handen om man vill ha ordet. Motståndet mot att delta i samtalet kan också bottna i att barnet själv vill visa om och när man vill delta och med det ha möjlighet att kontrollera sitt deltagande. Möjligen beror lärarens handlade på att läraren vet vilka barn som kanske inte alltid själva visar att de vill delta i samtalet och därför ger barnet ordet utan att denne visat att den vill ha det. Möjligen kan det också vara så att läraren vill att samtliga barn ska delta i samtalet runt den planerade aktiviteten.

\section{Sammanfattning}

I detta kapitel framkommer att läraren använder sig av olika verktyg och handlingar för att skapa möjligheter för barnen att delta i samtalet. Läraren ställer öppna frågor där en fråga kan ha olika svar, vilket skapar fler möjligheter för barnen att delta i samtalet. Beroende på hur mångordigt barnet sedan svarar avgränsar läraren samtalet eller stödjer med följdfrågor, vilket gör att barnen får ungefär lika stort talutrymme. Med detta följer också att möjligheterna till ett mer fördjupat samtal blir begränsade. Samtalsmönstret i klassrummet präglas av att läraren ställer frågor, barnen svarar och läraren återkopplar genom att evaluera, följa upp svaret med en ny fråga eller utveckla svaret själv (IRE/F). Läraren återkopplar även på ett barns svar genom att exempelvis repetera det som ett barn har sagt. Lärarens återkoppling riktar sig mot både barnens beteende i klassrummet och mot det innehåll som samtalet har där valet av samtalsämne i hög grad bestäms av läraren. Under ett samtal kan barnen såväl med talspråket som med kroppsspråket visa sitt ointresse. Genom att använda namnkort eller 
att "gå laget runt" skapar läraren en turordning där samtliga barn deltar i samtalet. Genom handuppräckning låter läraren barnen själva bestämma om och när de vill delta i samtalet även om det sedan är läraren som vanligen styr vilka barn som får ordet. Barnen socialiseras på så sätt in i ett elevbeteende där de förväntas räcka upp handen när de vill ha ordet.

I detta kapitel framkommer även att läraren kan handla motstridigt i situationer då barnen tar initiativ till att delta i samtalet. När läraren först nekar ett barn som vill delta i samtalet, men strax efteråt ger ordet till barnet då barnet fortsätter räcka upp handen, framstår handlingarna som motstridiga. Läraren kan dessutom handla motstridigt när hon tar initiativ till samtal med barnen. Läraren instruerar barnen i början av samtalet om att de ska räcka upp handen om de vill ha ordet, men sedan till viss del frångår detta när hon också ger ordet till barn som inte själva visat att de vill svara. Handlingarna står då i strid med varandra och kan därigenom bli motsägelsefulla för barnen, vilket kan göra det svårt för vissa barn att veta vilket beteende som förväntas. 


\section{Skriftspråket}

Detta kapitel handlar om mötet mellan läraren och barnen då de under lärarledda aktiviteter arbetar med skriftspråket, det vill säga med läsning och skrivning. Det är hur läraren och barnen i interaktion med varandra handlar och hur det skapar möjligheter för barnen att delta i olika skriftspråksorienterade aktiviteter som är i fokus.

Arbete med skriftspråksorienterade aktiviteter innebär att skriftspråket kan vara utgångspunkten för en gemensam aktivitet exempelvis att arbeta med rim eller att högläsa en bok. Men det förekommer också inslag av skriftspråksarbete under andra lärarledda aktiviteter, det vill säga aktiviteter som inte primärt syftar till att träna skriftspråket. Det händer exempelvis när läraren och barnen har matematik och det i en uppgift ingår att barnen ska skriva en mening till det matematiska innehåll som de arbetar med.

\section{Arbete med den grammatiska koden}

I följande avsnitt är det den grammatiska koden som står i fokus. I analysen av det empiriska materialet har tre underteman identifierats som var och en innehåller ett antal literacyhändelser: (a) språkets ljud (b) ord och (c) mening.

I undertemana språkets ljud, ord och mening framkommer att det pågår ett arbete med språkets form och/eller innehåll. När läraren och barnen arbetar med exempelvis rimövningar är det språkets form som fokuseras. När läraren exempelvis förklarar ett ord för barnen är det språkets innehåll som står i fokus. Möjligen kan läsaren uppfatta att arbetet med språkets form och innehåll skett avskilt från varandra, vilket inte är fallet utan är en analytisk konstruktion i syfte att göra det tydligt för läsaren vad som händer i förskoleklassen då läraren och barnen arbetar med den grammatiska koden.

\section{Språkets ljud}

Arbete med språkets ljud utgör ett centralt inslag i förskoleklassen exempelvis genom olika rimövningar. Inför eller under en rimövning förklarar läraren för barnen hur man rimmar genom att hon hänvisar till att ljud ska återkomma i de ord man säger, men ibland ger hon ingen förklaring till hur man rimmar. Det förekommer också att barnen får förklara och även de hänvisar till att ljud ska upprepas i ord man säger eller så förklarar barnen med att rimma på egna ord. Läraren läser också böcker som är uppbyggda 
på rim med barnen. Det kan ske under tiden som barnen till exempel har fruktstund. Vid dessa tillfällen är ofta alla barnen i förskoleklassen samlade i en ring på golvet tillsammans med läraren. Läraren läser texten utan avbrott och barnen lyssnar. Det förekommer även att läraren gör barnen aktiva i läsandet genom att hon läser en mening och sedan får barnen i kör eller enskilt avsluta meningen med att tala om vilket ord som rimmar. Läraren läser till exempel "Jag vet bäst sa en..." och barnen avslutar meningen genom att säga "häst”. En annan rimövning som förekommer i förskoleklassen är Rim-memory. Denna övning genomförs under ett gruppmoment och läraren och barnen sitter även här i en ring på golvet. Innan spelet börjar lägger läraren ut små kort på golvet med bildsidan neråt. Sedan ska ett barn i taget vända upp ett av korten för att därefter komma ihåg var ett tillhörande kort finns som rimmar till den bild man valt. Om barnet tar rätt kort får barnet paret och drar ett nytt kort. Om korten inte rimmar lägger barnet ner båda korten på samma ställe där man tog dem och nästa barn som står på tur får dra ett kort. Ett ytterligare sätt att arbeta med rim är att läraren använder bilder till vilka barnen i kör eller enskilt ska berätta vilka två bilder av tre som rimmar eller att hon visar en bild som barnen själva ska komma på ett rimord till. Ibland talar läraren om vad en bild föreställer innan barnen rimmar på den, men det förekommer också att barnen får berätta vilket motiv bilden har. En liknande uppgift kan barnen sedan själva arbeta med då de får ett papper med olika bilder där de ska dra streck mellan de bilder vars ord rimmar. När ett barn inte vet vad en bild föreställer eller inte vet vilka bilder som rimmar frågar de antingen läraren eller en kamrat.

I nedanstående sekvens har barnen precis lyssnat klart på läraren Helene som läst i boken om Trulle och Rim Tim.

\section{Exempel 7:1 Nu ska vi rimma}

Läraren: Vet någon hur man rimmar?

Ett antal barn rimmar högt. Det hörs gris-fis; råtta-potta, hus-mus.

Läraren: Just det, rim ska låta lika

Helene plockar fram en guldkartong och tar bort locket. Hon stoppar ner handen i kartongen och tar fram en mängd småbilder. Helene säger att hon ska visa en bild och att barnen sedan ska rimma till bilden. När Helene berättar vad de ska göra ger många barn glada tillrop och några börjar också rimma på egna ord. Den första bilden som Helene visar föreställer en byxa. Många barn svarar högt yxa. Helene uppmanar barnen att räcka upp handen och inte svara rakt ut. Helene visar en strid ström av bilder och till varje bild ger ett barn ett rimord. Några av barnen sitter uppe med handen hela tiden även om de precis rimmat till en bild. En bild visar ett skägg och Helene ger ordet till en flicka. 
Flicka 1: $\quad$ Skepp

Läraren: Men, låter det likadant?

Flickan tittar ner i golvet och Helene ger ordet till en annan flicka.

Flicka 2: $\quad$ Ägg

Läraren: Bra, det låter likadant

(Observation, 2012-09-03)

Helene ställer frågan hur man rimmar och barnen svarar med att själva rimma på olika ord, vilket Helene bekräftar med "Just det, rim ska låta lika". Helene instruerar barnen om hur den gemensamma rimuppgiften ska gå till och ett antal barn uttrycker en spontan glädje. När Helene visar den första bilden föreslår flera barn samma rimord. Därefter får ett barn i taget ge ett rimord till den bild som Helene visar och samtliga svarar med ett korrekt rimord förutom en flicka som säger "skepp" till bilden som föreställer ett skägg. Helene låter då ett annat barn ge ett rimord. Läraren i ovanstående exempel svarar på hur man rimmar genom att positivt bekräfta barnens rimord och att rim ska låta lika, vilket inte ger en förklaring till var i orden det låter lika. Ett antal barn uttrycker en spontan glädje över rimövningen, vilket visar ett intresse för att delta i övningen. När barnen rimmar till givna bilder bestämmer de först själva vad bilderna föreställer för att därefter hitta ett rimord som passar till, vilket många av barnen löser. Genom att barnen kan rimma på egna ord finns möjligheten att de tyst kan lyssna ut hur ljuden i orden de valt låter. Flickan som föreslår ordet skepp till bilden av ett skägg väljer emellertid ett ord där det initiala ljudet låter lika som ordet för vad bilden föreställer, vilket läraren inte uppmärksammar och därmed inte kommenterar. I ovanstående övning fokuseras språkets form. Barnen får lyssna på rim och själva rimma. I rimövningen riktas barnens uppmärksamhet mot språkets ljudmässiga uppbyggnad och med det behöver de bortse från vad orden betyder. Övningen fokuserar således på hur något sägs istället för på vad som sägs.

I sekvensen framkommer att en flicka svarar med ett ord som inte rimmar och när läraren inte uppmärksammar flickans svar går en möjlighet bort att samtala om var i ord det låter lika när man rimmar. Flickans svar hade på så sätt kunnat användas som en medierande resurs för att samtala om varför ordet inte rimmar med det ord som bilden föreställer. Ett svar som är felaktigt kan på så sätt användas som en hjälp i barnens lärande. Flickan ger ett ord som inte rimmar vilket visar att hon inte på egen hand lyckas lösa uppgiften med att hitta ett rimord som passar till bilden. När hjälp och stöd för att lösa uppgiften uteblir hamnar det som ska läras i övningen utanför det område som flickan på egen hand har möjlighet att behärska, det vill säga utanför hennes proximala utvecklingszon. 
Flera av barnen visar således intresse för att arbeta med rimord och under tiden som aktiviteten pågår är de engagerade och aktiva i rimmandet. Det finns också barn som uttrycker ett motstånd när läraren berättar att de ska arbeta med rim.

Exempel 7:2 Jag kan redan rimma

Läraren: $\quad$ Nu ska vi jobba med rim

Pontus: $\quad$ Åh, nej! Det är tråkigt, tråkigt, tråkigt. Jag kan redan allt. Det har jag jobbat med på dagis. Pling-ling; hus-mus; råtta-potta [hög stämma]

Läraren: $\quad$ Såja, ta det lugnt nu

Pontus Jag kan allting, vet allting (...) Tråkigt

Läraren Evy tittar på Pontus, men säger ingenting. Ett par andra barn instämmer med Pontus och säger att de också redan kan rimma. Evy tittar ner i sitt knä, där hon har en bunt papper. På varje papper finns tre motiv målade. Två av motiven rimmar. Hon lägger fram ett papper mitt i ringen så att alla barnen kan se. Evy undrar vad som rimmar.

(Observation, 2012-09-24)

När Evy introducerar övningen om rim protesterar Pontus och uttrycker att han redan kan rimma. Med hög röst säger Pontus några ord som rimmar och Evy ber honom lugna sig innan hon sedan sätter igång den övning som hon har planerat för. Då Pontus visar att han redan kan rimma är hans reaktion möjligen ett uttryck för att han inte ser någon mening med att arbeta med rim och därför gör motstånd mot den planerade övningen. Då Pontus ger exempel på rimord, visar han också att han är medveten om sina egna rimkunskaper.

Ovanstående övning verkar således inte utnyttja Pontus närmaste utvecklingszon. Övningen ligger på en nivå som han redan behärskar och det som ska läras utgör inte någon utmaning för honom. Övningen erbjuder därmed små möjligheter för Pontus att utnyttja den lärandepotential som finns i hans närmaste utvecklingszon.

Ett återkommande mönster i förskoleklassen är att läraren uppmärksammar barnen på de enskilda ljuden i talade ord. Läraren ljudar exempelvis något av barnens namn och frågar sedan vilka ljud namnet innehåller. Ett annat exempel är att läraren ber barnen ta bort sista ljudet i ett ord och frågar vilket nytt ord som bildas, till exempel "Om man tar bort /l/ från bil, vad får man för ord då?”. Vanligtvis ljudar läraren det ord som hon ber barnen ta bort ett ljud ifrån. Läraren kan även be barnen lägga till ett ljud i ett ord som hon uttalar högt.

Läraren kopplar emellanåt också samman ljud och bokstäver, ofta i kombination med skriven text. När läraren till exempel skriver ett ord på 
whiteboardtavlan ljudar hon samtidigt ordet för att sedan tala om vilket ord det blev. Det förekommer även att läraren pekar på varje bokstav i ordet eller drar sitt pekfinger under ordet samtidigt som hon ljudar det. Ibland frågar hon barnen vad hon har skrivit och som regel är det alltid något barn som ger det rätta ordet. Läraren uppmärksammar barnen på att ord både stavas och inte stavas som de låter när man uttalar dem. De räknar till exempel gemensamt antalet ljud och bokstäver i ord. Att räkna antalet ljud och bokstäver i ord samt ljuda ut ordet är ett vanligt förekommande inslag i verksamheten. Det kan exempelvis ske då de byter dagens eller veckans frukt- och/eller plingvärd.

Hos Ulla och barnen sker ett byte av plingvärd varje dag. Att vara plingvärd innebär att ett barn får klinga i en liten klocka när olika aktiviteter ska byta av varandra. Det här är ett uppskattat uppdrag som barnen gärna vill ha. Byte av plingvärd förekommer vid morgonsamlingen och alla barnen är då närvarande. Gårdagens plingvärd får dra en namnlapp ur en burk och det barn som har sitt namn på lappen får vara dagens plingvärd. I nedanstående sekvens är det Edvins tur att dra en namnlapp ur burken.

Exempel 7:3 Hur många ljud finns det i namnet?

Edvin stoppar ner sin hand i burken, tar upp en papperslapp och viker upp den.

Edvin: $\quad$ Sandra

Läraren: Oj, det gick snabbt. Hur visste du det?

Edvin: $\quad$ Det är S a n d r a [bokstaverar]

Läraren: $\quad$ Då kan vi ljuda det tillsammans då

Alla: $\quad$ /S-a-n-d-r-a/

Ulla tar papperslappen från Edvin och håller upp den så att alla barnen kan se den.

Läraren: Vi ljudar igen och titta här [pekar samtidigt på bokstäverna på papperslappen]

Alla: $\quad$ /S-a-n-d-r-a/

Läraren: Hur många ljud finns i Sandras namn?

Många av barnen räcker upp händerna.

Läraren: Tanja

Tanja: $\quad$ Fem

Läraren: Vi ljudar tillsammans igen

Alla: $\quad$ /S-a-n-d-r-a/ [läraren håller upp ett finger för varje ljud]

Läraren: Vad blev det, Tanja?

Tanja: $\quad$ Sex

(Observation, 2012-12-07) 
Ulla och barnen ljudar först ihop språkljuden i det uttalade namnet utan att läraren visar papperslappen med det skrivna ordet, för att sedan tillsammans ljuda samman namnet samtidigt som Ulla pekar på bokstäverna. På frågan om antalet ljud ger ett barn ett felaktigt svar och alla ljudar återigen samman språkljuden samtidigt som Ulla med fingrarna visar antalet ljud i namnet, vilket hjälper barnet att ge det rätta antalet. Läraren väljer att i övningen använda ord som är nära förknippade med barnen då hon använder deras förnamn. Läraren synliggör relationen mellan bokstav och ljud för barnen genom att peka på bokstäverna på papperslappen samtidigt som de tillsammans ljudar ihop språkljuden. Genom att läraren pekar på bokstäverna visar hon för barnen i vilken riktning man läser ihop dem och att ord blir till genom att bokstäver sätts samman i en bestämd ordning. Tillsammans delar de också upp namnet i antalet ljud och läraren visualiserar antalet med sina fingrar för barnen. Övningen ingår i ett sammanhang där ett barn ska få eller har haft ett uppdrag som de gärna vill ha. I exemplet ovan riktas barnens uppmärksamhet mot språkets minsta beståndsdelar det vill säga bokstäver (grafem) och ljud (fonem). Övningen ger barnen möjlighet att träna på att segmentera ord i bitar av fonemstorlek, men även att ljuda samman fonem till ord, det vill säga göra en syntes. Då läraren knyter samman ljud och bokstav genom att peka på det skrivna ordet på papperslappen ges barnen möjlighet att öva på att avkoda ord. Genom att arbeta med bokstäver och ljud i ord som ligger nära barnen, i det här fallet barnens namn, kommer övningen och därmed träningen av sambandet mellan grafem och fonem in i ett meningsfullt sammanhang.

Den hjälp som läraren ger Tanja kan ses som stödstruktur för att hon ska ha möjlighet att svara på frågan om antalet ljud i det efterfrågade namnet. Lärarens fingrar verkar fungera som en medierande resurs för att Tanja ska lyckas med detta.

\section{Ord}

En annan aktivitet som förekommer i förskoleklassen är övningar med sammansatta ord. Läraren illustrerar för barnen vad sammansatta ord är genom att säga två ord som hon sedan sätter samman till ett ord eller genom att säga ett sammansatt ord som hon sedan delar upp i två ord. Det förekommer också att läraren samtidigt som hon förklarar använder sina händer och låter ett ord "vara i varje hand" och antingen drar ihop sina händer eller drar isär dem, beroende på om hon vill visa för barnen hur ord kan sättas samman eller hur ord kan dras isär. När barnen förklarar vad ett sammansatt ord är svarar de till exempel "Två ord man sätter ihop" eller så ger de något exempel "Mask och ros, maskros" eller "Fotboll, fot och boll".

Ett exempel på arbete med sammansatta ord är när läraren visar en bild för barnen och sedan ska barnen själva komma på ett ord som kan sättas 
samman med ordet för vad bilden föreställer. Barnen visar att de vill svara genom att räcka upp handen. Ibland får vissa barn svara flera gånger då de räcker upp handen till flera av de bilder som läraren visar. Andra räcker inte alls upp handen och deltar därmed inte i att föreslå ord till de bilder som läraren visar. Det förekommer också att läraren går i tur och ordning efter hur barnen sitter i ringen och på så sätt får alla barn en bild som de ska ge ett ord till. Om ett barn inte vet vad en bild föreställer hjälper läraren eller andra barn till genom att tala om vad bilden föreställer. Det förekommer även att läraren ljudar bildens första bokstav och då brukar barnet säga vad bilden föreställer. Någon gång händer det att ett barn inte kommer på ett ord som kan sättas samman med den bild som läraren visar och då ber läraren ett annat barn att svara. Ibland hinner dock kamraterna viska ett ord till kamraten innan läraren lämnar över ordet till någon annan. Vanligen får det barn som inte kunnat svara en ny chans genom att läraren visar barnet ytterligare en bild. Det brukar resultera i att barnet föreslår ett ord som kan sättas samman med det ord som bilden föreställer. En liknande uppgift kan barnen därefter själva arbeta med då de får ett papper med olika bilder där de ska dra streck mellan de bilder vars ord kan sättas samman till ett ord. När ett barn inte vet vad en bild föreställer eller inte vet vilka bilder vars ord kan sättas samman till ett ord frågar de antingen läraren eller en kamrat.

Ett annat sätt att arbeta med sammansatta ord är att spela bingo, vilket Evy och hälften av barnen i förskoleklassen gör i nedanstående sekvens. Innan de börjar spela delar Evy in barnen i grupper om tre och varje grupp får var sin spelbricka med sexton bilder. Hon ger också barnen ett antal små gula markörer.

\section{Exempel 7:4 Spela spel med sammansatta ord}

Evy förklarar att ett barn ur varje grupp ska lägga en markör på den bild på spelbrickan som föreställer det sammansatta ord som bildas när man lägger ihop de två bilder som hon har på ett kort. Hon visar upp en spelbricka för barnen och förklarar att man har bingo när man har fyra markörer i rad. Samtidigt som Evy förklarar drar hon sitt pekfinger längs en lodrät och en vågrät rad på spelbrickan. Evy tar korten ur spellådan och lägger dem upp och ner på den blå mattan. Några av barnen hoppar då lite upp och ner där de sitter. Ett par av barnen tittar på varandra med stora ögon samtidigt som de ler. Evy drar ett kort och vänder upp det mot barnen. Det första kortet visar en bild av ett glas och två ögon. Mellan bilderna finns ett plustecken. Barnen säger "glasögon” och Evy nickar instämmande. Därefter lägger ett barn i varje grupp en markör på den bild som visar ett par glasögon. [...] Evy drar nästa kort och visar upp för barnen. Det är bild av en spindel och ett nät och barnen säger "spindelnät”. Ett barn i varje grupp lägger en markör på bilden som föreställer ett spindelnät.

(Observation, 2012-09-26) 
Evy instruerar barnen muntligt om hur uppgiften ska gå till. Hon använder även sitt kroppsspråk där hennes pekfinger visar hur barnen får bingo. När Evy inleder bingospelet med sammansatta ord uttrycker några av barnen sin iver med kroppen. Evy visar olika kort för barnen och de svarar i kör de korrekta sammansatta orden. Då läraren ger barnen instruktioner om hur uppgiften ska genomföras gör hon det möjligt för barnen att rikta uppmärksamheten mot hur de ska ta sig an uppgiften. Barnen visar med sitt kroppsspråk att de är ivriga att delta vilket tyder på att det finns intresse för övningen. Genom att spela bingo får barnen möjlighet att för sig själva fundera ut och sätta ord på vad två bilder föreställer för att sedan sätta samman orden till ett ord, vilket många av dem lyckas med på ett korrekt sätt. I ovanstående övning riktas barnens uppmärksamhet mot språkets minsta betydelsebärande enhet, det vill säga morfemet. Genom att sätta samman två ord till ett ord får barnen möjlighet att erfara att ett nytt ord bildas och att det ordet också uttrycker en ny betydelse. Övningen riktar därmed också barnens uppmärksamhet mot språkets innehåll, det vill säga språkets semantiska sida.

Lärarens muntliga och icke verbala instruktioner kan ses som stödstrukturer för att barnen ska ha möjlighet att genomföra uppgiften. Barnens sätt att förstå hur uppgiften ska genomföras medieras på så sätt genom lärarens handlingar.

När barnen arbetar med uppgifter som de uttrycker att de redan kan eller redan har gjort på ett liknande sätt förut förekommer det att barnen själva ger förslag till att förändra eller försvåra uppgiften. Ibland anammar läraren ett förslag, men oftast gör hon inte det. I den sekvens som beskrivs ovan kommenterar sedan några barn hur lätt uppgiften är och att de "vill ha något svårare". Evy svarar inte utan visar barnen ett nytt kort. Kortet visar en häst och en sko och i kör säger barnen "hästsko". Spelet fortsätter på liknande sätt tills en grupp ropar "bingo". Gruppen som fått bingo berättar vilka bilder de lagt markörer på och Evy kontrollerar så att det stämmer med de kort som hon har visat upp för barnen.

\section{Exempel 7:5 Vi vill läsa orden}

Barnen ger ett glädjetjut när Evy säger att deras bingo stämmer. Barn från de övriga grupperna stönar när de hör att de har bingo. På baksidan av spelbrickan finns ordet skrivet istället för en bild av det och några av barnen uttrycker önskemål om att hellre använda den sidan. Evy svarar:

Läraren: Det finns barn som inte kan läsa 
Evy sätter igång en ny spelomgång. Några barn stönar högt och ett par barn säger ”Jag kan”.

(Observation, 2012-09-26)

Några av barnen föreslår att de ska läsa de sammansatta orden, vilket Evy motsätter sig med förklaringen att alla barn inte kan läsa. Några barn invänder mot den förklaring som Evy ger då de menar att de kan läsa. Genom att några av barnen föreslår att de ska läsa de sammansatta orden istället för att använda bilderna försöker de göra uppgiften mer utmanande. Läraren anammar inte det förslag som barnen ger med förklaringen att alla barn inte kan läsa och på så sätt går en möjlighet att öva på att avkoda ord bort. Även en möjlighet för barnen att lagra orden som bilder och att tala om vad ett ord betyder i olika sammanhang går förlorat.

Lärarens svar till barnen om att "Det finns barn som inte kan läsa” kan ses som att läraren anpassar aktiviteten och sitt stöd utifrån den samlade gruppens närmaste utvecklingszon. För vissa barn ligger troligen stödet på rätt nivå medan det för andra ligger på en nivå där de sannolikt inte utmanas i sitt lärande och således inte behöver anstränga sig.

Ovanstående pekar på att det finns barn som visar ett intresse för att spela bingo med sammansatta ord, men när läraren inleder den ovanstående sekvensen med att först berätta vad de ska arbeta med uttrycker också några av barnen ett motstånd.

\section{Exempel 7:6 Det har vi redan gjort}

Läraren: Då, äntligen ska vi börja, ssch nu! Idag ska vi jobba med sammansatta ord Några: $\quad$ Åh, nej!

Anton: Det har vi redan gjort

Flicka: $\quad$ Det gjorde vi på dagis

Johan: Ja, det är tråkigt, tråkigt. Vi har gjort det massor av gånger ju!

[...] Sedan berättar Evy att de ska spela ett bingospel med sammansatta ord och visar upp spelet för barnen. Några barn säger att de spelat just det spelet på dagis, men Evy menar att bingo kan man spela många gånger och att det inte gör något att man spelat spelet förut.

(Observation, 2012-09-26)

När Evy introducerar aktiviteten med sammansatta ord gör några av barnen motstånd genom att berätta att de redan har gjort det i förskolan och även att de spelat just det spelet som läraren har planerat för. Evy bemöter barnens invändningar med att tidigare erfarenheter av materialet inte har så stor betydelse. Avsnittets inledande sekvens (exempel 7:4) visar dock att när läraren sedan påbörjar själva bingospelandet visar barnen ett intresse 
för spelet. Måhända är det mer att spela själva spelet som gör aktiviteten lockande än att arbeta med sammansatta ord. Spelet som sådant innehåller bland annat ett tävlingsmoment där det handlar om att bli den grupp som först får bingo, vilket i sig kan vara lockande och bidra till att barnen vill arbeta med uppgiften. Spelet blir på så sätt ett medierande redskap för att locka barnen till att arbeta med ett specifikt innehåll och som i denna situation visar sig vara sammansatta ord.

En annan aspekt av att arbeta med ord i förskoleklassen är att förklara ord. När läraren och barnen stöter på ord som läraren antar att barnen inte vet betydelsen av förklarar hon ordet eller så ber hon något barn förklara. Det händer också att något barn undrar vad ett ord betyder och då kan läraren förklara ordet. Det förekommer även att ett annat barn förklarar det ord som ett barn undrar över. Förklaringar av ord kan förekomma när som helst under de lärarledda aktiviteterna. Exempelvis när de läser dagens lunch och inte vet vad alla ord i den maträtt de senare ska äta betyder, när läraren läser ur en bok eller när någon berättar något under morgonsamlingen och använder ett ord som inte är så vanligt förekommande.

\section{Exempel 7:7 Vad betyder ordet?}

Läraren Helene sätter sig vid pianot och vänder sig mot barnen.

Läraren: Kommer ni ihåg igår? Då hade vi någon här. Han var här väldigt länge under den fria leken. Han som stämde pianot, vad menas med det?

Ett antal barn räcker upp händerna och några barn svarar utan att ha fått ordet.

Läraren: Lucas, kan du berätta?

Lucas: $\quad$ För att se om det låter bra

Läraren: Ja, så kan man säga. För att det ska låta vackert när man spelar. Vi fick också lära oss ett till nytt ord igår. Kommer ni ihåg, flexibel. Vad betyder det?

Händer kommer upp i luften och återigen börjar några av barnen prata rakt ut. Helene ger ordet till Alex samtidigt som hon säger att de ska räcka upp handen om de vill svara.

Alex: $\quad$ Om jag vill rita, men så händer det något och då får jag göra något annat Läraren: Då var du flexibel, just det. Han var ju här väldigt länge och vi kunde inte vara här då för då hör han ju inget och då fick vi vara flexibla

(Observation, 2012-11-29) 
Helene följer upp och repeterar ord som de tidigare förklarat betydelsen av och som barnen då inte visste innebörden av. Två av barnen förklarar var sitt ord och Helene styrker deras rätta förklaringar med andra ord. I den här situationen kontrollerar läraren om barnen kommer ihåg vad ord betyder som de tidigare fått förklaringar på. Att barnen förklarar orden med egna ord visar att de förstår innebörden av dem. En kunskap de troligen inte hade tidigare och med det kan fler ord ha tillkommit i barnens ordförråd. När läraren ger respons på barnens förklaringar gör hon det genom att vidareutveckla deras svar. I ovanstående exempel riktas barnens fokus mot språkets innehåll. Genom att svårbegripliga ord får sin förklaring efterhand som läraren och barnen möter orden i olika situationer så får de sin betydelse i ett konkret sammanhang. Att barnen får lära sig nya ords betydelser och på så sätt ha möjligheten att bygga ut ordförrådet bidrar också till läsinlärningen genom att barnen får en större förståelse för de texter de läser.

\section{Mening}

Arbete med språkets ljud, bokstäver och ord ingår i ett sammanhang där läraren och barnen skriver en fullständig mening. Läraren uttrycker det som att "Alla skriver meningen som står på tavlan” eller "Alla ska skriva en mening”. När barnen får höra detta kan några svara med att stöna ljudligt eller fråga "Måste man?”, vilket läraren alltid svarar jakande på. Emellanåt bestämmer läraren vilken mening alla barnen ska skriva och för att barnen ska se vilken mening det är skriver hon den på whiteboardtavlan. Ibland berättar läraren vad hon tänker skriva innan hon skriver meningen på tavlan, ibland skriver hon meningen först och talar sedan om vad hon har skrivit. Det förekommer även att läraren skriver ett ord i taget och efterhand talar om vad hon skriver. Ibland ljudar läraren också ordet samtidigt som hon skriver det. Läraren kan uppmärksamma barnen på att hon sätter ut en punkt när hon avslutar meningen på tavlan. Läraren säger "Så slutar man alltid en mening med punkt”. Ibland svarar barnen att de redan vet när man ska sätta ut en punkt och att läraren därför inte behöver tala om det. Läraren skriver meningen med versaler eller med gemener. Att alla barnen skriver den mening som läraren valt och som hon också skrivit på whiteboardtavlan förekommer exempelvis under en matematikaktivitet då Ulla och barnen arbetar med en så kallad "mattekluring”. Barnen har löst problemet och är nu igång att rita lösningen i sina räknehäften. Under tiden som barnen arbetar skriver Ulla "Pia har fyra bollar.” på whiteboardtavlan.

Exempel 7:8 Skriv meningen "Pia har fyra bollar."

Ulla ber barnen stanna upp lite och titta på det hon har skrivit. 
Läraren: Då skriver ni också meningen ”Pia har fyra bollar.”

(Observation, 2013-04-22)

Ulla högläser den mening som hon har skrivit och uppmanar barnen att skriva samma mening. Ulla poängterar att det som hon har skrivit är en mening genom att hon uttrycker ordet "meningen" innan hon läser vad som står. Genom att läraren i exemplet högläser den skrivna meningen underlättar hon för barnen att upptäcka att talade ord kan översättas i skrift. När läraren poängterar att det som hon har skrivit är en mening och sedan läser orden visar hon att en mening innehåller ett antal ord från vänster till höger.

Genom att läraren formulerar den mening som samtliga ska skriva ges inte barnen någon möjlighet att vara med och påverka innehållet i den mening som de ska skriva. Det finns barn som uttalar ett motstånd mot att skriva en given mening genom att uttrycka "Måste man?”. Möjligen kan barnens motstånd ha sin grund i att de själva inte kan vara med och påverka innehållet, men det kan också vara så att de upplever skrivandet som svårt eller jobbigt.

Det förekommer emellertid att barnen själva får bestämma vilken mening de ska skriva, men med förbehållet att meningen utgår från det innehåll som en aktivitet har. När barnen frågar läraren om de ska skriva orden i sin mening med versaler eller med gemener säger hon att barnen får välja. En lärare berättar att hon rådfrågat sina kollegor i årskurs 1 om de tycker att barnen i förskoleklass ska skriva bokstäverna med versaler eller med gemener. Läraren säger att hon har fått olika svar från kollegorna då vissa tycker att barnen bara ska skriva med versaler medan andra menar att barnen ska skriva med både versaler och gemener. Eftersom hon har fått olika svar från lärarna menar hon att barnen i förskoleklass själva får välja med vilka bokstäver de ska skriva sina ord ${ }^{9}$. När ett barn frågar läraren om hur en bokstav ser ut eller hur den ska formas hänvisar läraren till de bokstavsplanscher som finns uppsatta på någon av väggarna i klassrummet. En av bokstavsplanscherna har pilar utritade för i vilka steg varje bokstav i alfabetet ska skrivas. Barnen kan ha en miniatyr av denna bokstavplansch i sin låda som de kan ta fram när de ska skriva en bokstav. Läraren kan också visa hur den efterfrågade bokstaven ska formas genom att skriva bokstaven på ett separat papper för barnet. När ett barn undrar över hur ett ord stavas frågar de varandra eller läraren som då hjälper till genom att ljuda eller bokstavera ordet. Ibland tar barnet hjälp av det textmaterial som finns i klassrummet för att på så sätt få hjälp med hur ett ord stavas. Det

9 Fältanteckning, informellt samtal 2012-09-13. 
förekommer även att barnet talar om för läraren vilken mening hon eller han vill skriva. Läraren skriver den valda meningen på ett papper och barnet skriver sedan av meningen i sin skrivbok. Barnen bestämmer själva om de vill ha sin mening skriven på ett papper eller som läraren och barnen kallar det "ha en fusklapp". Antingen går läraren runt bland barnen och skriver fusklappar efterhand eller så får barnen innan skrivandet tar vid ställa sig på ett led framför läraren för att få en. Innan barnen börjar skriva sin mening hjälps de åt med att ge förslag på meningar som barnen kan skriva. Barnen uttrycker sig inte alltid i fullständiga meningar när de ger förslag på vad de kan skriva, men det är ett krav när de sedan formulerar sin mening i skrift.

Ett tillfälle då barnen själva får välja vad de vill skriva är när de skriver om veckans händelser. Då barnen ger förslag på vad de har gjort säger de exempelvis "Jobbat med rim", "Ritat gubbar" eller "Vi har haft friidrott". Ibland fyller också läraren på med något som de har gjort när barnen inte själva kommer på allt. Efter att läraren och barnen samtalat om vad de har gjort hämtar barnen veckoböckerna i sina lådor och sätter sig på sina platser vid borden. Det veckobrev som läraren skrivit klistrar barnen in på en sida av boken och på den andra sidan skriver barnen sin valda mening. Ibland gör barnen också en bild till den mening som de har skrivit.

I nedanstående sekvens sitter Alex, Hampus, Ebba och Alicia vid ett av de runda borden i klassrummet. Alex, Hampus och Ebba är igång med att skriva sina respektive meningar i veckoboken. Alex sitter med en bok om Trulle framför sig och skriver av ordet Trulle. Hampus och Ebba skriver utan någon förlaga då de menar att "Vi kan ju skriva”. Alicia har inte kommit igång med uppgiften. Hon sitter och tuggar på pennan och tittar ut genom fönstret.

Exempel 7:9 Vilken mening vill du skriva?

Efter en stund vänder sig Alicia mot kamraterna och frågar hur man skriver ”Jag”. Hon pekar på sig själv med pennan.

Hampus: /J-a/

Alicia tackar och börjar skriva. Barnen arbetar under småprat. Ibland frågar de varandra om stavningen på ett ord, vilken färgpenna de ska ta eller vad de ska rita för något. Prat och skratt genomsyrar rummet. Alicia skriver ordet "JA" och klistrar in det rosa veckobrevet. Därefter tuggar hon på pennan, ritar sig själv på armen och gör stora cirklar med pennan i luften. Efter en stund packar Alex, Hampus och Ebba ihop.

Alicia: $\quad$ Du, Ebba, vänta. Vad står det här? [pekar med fingret på ordet]

Ebba: $\quad$ Det står ”Ja”

Alicia blir ensam kvar vid bordet. Läraren Ella kommer fram till Alicia och sätter sig på en stol bredvid henne. 
Läraren: Vad tänkte du skriva?

Alicia: Jag vet inte. Jag tänkte skriva att jag haft gympa

Läraren: Det blir väl bra. Det vill nog mamma och pappa veta

Ella tar ett av de lösa papper som ligger på bordet och skriver ”JAG HAR HAFT GYMPA.”. Alicia tittar på medan Ella skriver.

Läraren: Här står det ”JAG HAR HAFT GYMPA.”

Alicia: $\quad \mathrm{Hm}$

Läraren: Om du vill kan du ju rita en bild till också

Ella lägger pappret framför Alicia. Alicia tar sin blyertspenna och börjar skriva av det som Ella skrivit. Ella reser sig och börjar gå därifrån samtidigt som hon säger:

Läraren: Du kan komma ut till mig när du är klar så jag får se innan du stoppar ner den i väskan.

(Observation, 2012-09-05)

Alicia ber kamraterna om hjälp med stavningen av ordet "jag”. En pojke svarar genom att säga ordet så som det låter när man uttalar det varpå Alicia skriver ordet. På Ellas fråga berättar Alicia vad hon vill skriva, vilket bekräftas av Ella, som skriver ner meningen och sedan läser den högt. Alicia observerar vad Ella skriver och skriver därefter av meningen. Att Alicia frågar kamraterna om hjälp med stavningen på ett ord tyder på att hon vet att talade ord går att översätta till skrift, men det kan också vara så att hon vet att det finns rätt och fel när det gäller stavning. För att få hjälp vänder sig Alicia till kamrater som har mer erfarenhet av stavning än vad hon själv har. Då pojken ger en ljudenlig stavning blir det också så som Alicia skriver ner ordet. Alicia ber Ebba läsa och som då läser "ja”. När läraren skriver den mening som Alicia säger att hon vill skriva och sedan läser den högt åskådliggör läraren för Alicia hur man korrekt stavar de talade orden och hur en vedertaget skriven mening ser ut. Alicia verkar motiverad att göra på samma sätt som läraren då hon riktar uppmärksamheten mot det som läraren skriver och direkt börjar skriva av den mening som läraren skrivit. Även om ramen för skrivuppgiften är fastställd genom att barnen ska skriva var sin mening utifrån ett bestämt ämne öppnar den till viss del upp för en innehållslig frihet. Utifrån veckans arbete i förskoleklassen väljer var och en vilket moment man vill uttrycka i skrift. Barnen kan då också välja att använda ord som de redan kan skriva och har förståelse för eller så kan de pröva sin kunskap gällande ljud och bokstäver på ord där stavningen är mer obekant för dem. Barnen ges således möjlighet att arbeta med att uttrycka ett innehåll som ligger dem nära samtidigt som de också utforskar skriftspråkets regler. Genom att barnen själva får formulera en mening om vad de gjort under veckan ges de möjlighet att skriva om något som har ett vidare syfte än att träna skrivning, 
det vill säga att det skrivna är tänkt att läsas av mottagare som står barnen nära. Det finns barn som uttalar ett motstånd mot att skriva då de själva får välja vilket budskap en mening ska ha. Möjligen är motståndet ett uttryck för att barnen har svårt för att välja vilken mening de ska skriva då uppgiften utgår ifrån att barnen ska skriva en mening.

I ovanstående exempel kan hjälpen från kamraterna ses som stödstrukturer för att Alicia ska komma igång med skrivuppgiften och därmed ha möjlighet att skriva det första ord som hon vill uttrycka. Även den hjälp som läraren ger Alicia verkar fungera som stödstruktur för att Alicia sedan ska ha möjlighet att skriva hela sin mening. Alicia visar att hon är motiverad att göra på samma sätt som läraren och med det kan den skrivna papperslappen från läraren fungera som en medierande resurs för henne. Utifrån den motivation som Alicia visar genom att hon riktar uppmärksamheten mot det som läraren skriver och sedan genast skriver av meningen i sin skrivbok verkar det som att stödet ligger på rätt nivå och därmed inom ramen för Alicias närmaste utvecklingszon. Alicia visar emellertid att hon har erfarenhet av att koppla samman ljud och bokstav då hon sätter ihop ljuden med de rätta bokstäverna själv efter det att Hampus ljudat ordet för henne. Möjligen hade en uppmärksamhet mot det grammatiska skrivandet där läraren istället uppmuntrat Alicia att själv ljuda orden därför kunnat utmana Alicia än mer.

Uppgiften ger barnen en viss innehållslig frihet då barnen själva kan välja vilken mening och med vilka ord den ska skrivas, samt om stödstrukturer för att skriva meningen behövs. Det här kan göra det möjligt för samtliga barn att skriva utifrån den nivå de befinner sig på och därmed bli utmanade i sitt skrivande. Det verkar följaktligen som att uppgiften är utformad på ett sätt som gör det möjligt för barnen att skriva utifrån var och ens närmaste utvecklingszon.

\section{Högläsning}

I följande avsnitt är det högläsning av berättelser som står i fokus. I analysen av det empiriska materialet har två underteman identifierats som var och en innehåller ett antal literacyhändelser: (a) läsa med avbrott och (b) läsa utan avbrott.

I undertemana läsa med avbrott och läsa utan avbrott framkommer att det förekommer ett arbete med språkets innehåll och/eller språkets form. När läraren högläser och exempelvis gör avbrott i läsningen för att ställa frågor till barnen om berättelsens handling är det språkets innehåll som fokuseras. När ett barn exempelvis läser en berättelse delvis med flyt står både språkets innehåll och form i fokus. 


\section{Läsa med avbrott}

Vid högläsning läser läraren en berättelse. Hon avbryter läsningen emellanåt för att ställa frågor. Vid sin läsning berättar läraren inte i förväg att frågor kan förekomma om det lästa utan det sker som naturliga stopp under läsningen. Läraren ställer ibland frågor om innehållet innan läsningen börjar, men det kan även ske efter att hon har läst klart. Barnen svarar på frågorna enskilt eller i kör. Ibland ställer ett barn någon fråga om det lästa som antingen besvaras av läraren eller så lämnar läraren över frågan till ett annat barn. Oftast sker högläsningen när alla barnen i förskoleklassen är närvarande, men ibland förekommer detta under ett gruppmoment och då är ungefär hälften av barnen i förskoleklassen med.

Läraren kan också göra avbrott i läsandet för att visa barnen bilderna ur en bok. Ibland kommenterar läraren eller barnen den bild som visas. Om läraren läser och barnen samtidigt äter frukt förekommer det att läraren dessutom gör avbrott i läsandet då barn prasslar med de burkar som de har haft frukten i. Läraren brukar då be barnen att ställa burkarna en bit framför sig på golvet, vilket vanligen gör att prasslandet upphör. Någon gång förekommer det att barn småpratar med varandra, vilket också kan föranleda att läraren avbryter läsandet och ber barnen att lyssna på henne istället.

När läraren gör avbrott för att ställa frågor om det lästa frågar hon om sådant som kan knytas till berättelsens handling, vilket nedanstående sekvens är ett exempel på.

Ella och barnen i förskoleklassen är samlade i en ring på golvet. Belysningen i klassrummet är neddraget och i mitten av ringen står några värmeljus och brinner. Barnen småpratar med varandra och några av dem skrattar till då och då. Ella har den pågående högläsningsboken i handen. Hon viftar lite med boken. Sorlet i klassrummet klingar sakta ut. Barnen riktar efterhand sin blick mot Ella.

\section{Exempel 7:10 Vad har hänt?}

Läraren: Kommer ni ihåg vad som har hänt? Jag har ju inte varit med och läst på ett tag. Kan någon berätta?

Flera händer kommer i luften och några av barnen börjar berätta i munnen på varandra. Ella sätter upp en hand i luften samtidigt som hon ger ordet till Ida.

Ida: $\quad$ De ska till Stockholm

Läraren: Vilka är de?

Flicka Mamman och barnen

Ella slår upp en sida i boken. 
Läraren: Det är någon bild här med godis. Har de ätit det?

Alla: $\quad$ Ja

Läraren: $\quad$ Här står också att det finns någon som heter Lisa

Alla: $\quad$ Ja

Läraren: Och Olle

Alla: $\quad$ Ja

Emilie: $\quad$ De åker tåg

Ella börjar att läsa. Hon läser med olika röstlägen och emellanåt betonar hon också ord. Efter ett tag håller hon upp boken och visar en bild. De flesta av barnen tittar mot bilden och några kommenterar det de ser. Sedan fortsätter Ella att läsa tills hon frågar:

Läraren: Vad tror ni att de fått syn på nu? Varför blir det sådant liv?

Victor: $\quad$ En mus

Läraren: $\quad \mathrm{Hm}$

Ella läser vidare. Efter en stund hörs det skrik från hallen och Ella reser sig och stänger dörren samtidigt som hon fortsätter att läsa. Skriken försvinner bort och det blir återigen bara Ellas röst som hörs.

(Observation, 2012-11-27)

Ella inleder med en öppen fråga om vad som hittills hänt i berättelsen som flera av barnen vill svara på. Hon övergår därefter till att ställa ledande frågor där barnen svarar kort och koncist. En flicka gör ett eget inlägg då hon säger "De åker tåg”, men Ella följer inte upp hennes inlägg. När en bild finns i boken visar Ella den för barnen. Flertalet barn riktar då sin uppmärksamhet mot bilden och några kommenterar den också. Vid ett lässtopp ställer Ella ett par liknande framåtsyftande frågor. En pojke svarar och Ella bekräftar svaret med ett "Hm". När störande ljud uppkommer utanför klassrummet utestänger Ella ljudet genom att stänga dörren samtidigt som hon fortsätter att läsa. Genom att läraren låter barnen redogöra för vad som hänt vid tidigare lästillfällen får barnen med hjälp av hennes frågor möjlighet att sammanfatta berättelsen. De frågor som läraren ställer ger barnen olika möjligheter att besvara frågorna och läraren skapar på så sätt olika förutsättningar för att återberätta. Den öppna frågan ger möjlighet till ett längre berättande medan de ledande frågorna begränsar återberättandet då de besvaras med något enstaka ord. Inlägget "De åker tåg” följs inte upp av läraren, vilket gör att det inte uppstår någon dialog kring inlägget. När läraren ställer ett par liknande framåtsyftande frågor ges barnen möjlighet att förutspå den kommande handlingen i berättelsen. Troligen ger pojken ett rimligt svar eftersom läraren bekräftar svaret med ett "Hm”. Då de framåtsyftande frågorna i sig indikerar att svaret inte tidigare stått i texten så läser sannolikt pojken mellan raderna för att han ska kunna ge det svar som han ger. De olika sätt som läraren ställer frågor på gör att barnen får röra sig bakåt och framåt i berättelsens text. Genom att läraren visar bilden i boken riktas barnens uppmärksamhet mot att se 
relationen mellan text och bild. Eftersom många av barnen uppmärksammar bilden och några av dem kommenterar den verkar bilden vara viktig för barnen. Läraren följer dock inte upp barnens kommentarer med frågor så att en dialog skapas om texten och bilden utan hon väljer att läsa vidare. Då varken läraren eller barnen ger intryck av låta sig bli påverkade av det störande inslag som förekommer under läsningen verkar innehållet $\mathrm{i}$ berättelsen intressera och engagera barnen. De frågor som läraren ställer i ovanstående exempel riktar barnens uppmärksamhet mot berättelsens innehåll. När läraren ställer frågor som handlar om att sammanfatta eller förutspå handlingen tillämpar hon olika strategier för att ge barnen möjlighet att förstå texten. I avsnittet om Ord såg vi exempel på ordförklaringar som förekommer i förskoleklassen och som också sker då läraren högläser berättelser. Genom att läraren ställer frågor om ords innebörd och att de tillsammans reder ut vad ett ord betyder så tillämpar hon ytterligare en strategi för att ge barnen möjlighet att förstå en text.

Lärarens frågor i form av att barnen får sammanfatta, förutspå och förklara ord kan ses som stödstrukturer för att skapa mening och förståelse för en text. Då bilderna och texten hänger samman i boken kan även bilderna ses som stödstruktur för att bygga upp en förståelse för innehållet i berättelsen. Även om läraren inte muntligt uttrycker till barnen vilket stöd hon ger dem så stiftar barnen bekantskap med hur olika lässtrategier kan hjälpa till med förståelsen av en text. Genom att barnen tar del av en mer erfaren persons handlande och sätt att fråga kan barnen gradvis komma att själva använda stödstrukturerna vid senare lässammanhang. Situationen kan därmed ses som att barnen får möjlighet att börja appropiera kunskap som gör att de efterhand kan utveckla strategier för att förstå en text.

När läraren högläser en berättelse förekommer det även att hon ställer frågor som går bortom den direkta handlingen. Frågorna har, i relation till handlingen, då en anknytning till det som de arbetar med i förskoleklassen. Ett exempel på detta är när läraren läser berättelsen om Trulle och Rim Tim i samband med att de arbetar med en rimövning (exempel 7:1).

Läraren ställer också frågor med anknytning till de erfarenheter som barnen har i relation till berättelsens handling. Det händer även att något barn på eget initiativ berättar om sina erfarenheter av det som en berättelse handlar om utan att läraren frågar om det.

Helene och barnen i förskoleklassen är samlade i en ring på golvet. Helene sitter på en liten pall mellan två barn. Hon visar upp framsidan till boken Näpp! sa Alfons Åberg samtidigt som hon berättar att det är den boken hon ska läsa idag. Helene läser om Alfons och hans sätt att säga nej till saker och ting. Efterhand som hon läser visar hon bilderna för barnen. Då och då kommenterar Helene eller något barn det som finns på en bild. 
När några av barnen inte tittar på den bild som Helene visar ber hon dem titta på bilden varpå de vänder blicken mot den. Efter att ha läst en stund frågar hon:

Exempel 7:11 Berätta om dina erfarenheter

Läraren: Hur brukar era mammor och pappor bli när ni säger att ni inte vill?

Pojke 1: $\quad$ Det tycker de inte om

Pojke 2: $\quad$ Nä, man måste ju göra som de säger

Helene läser vidare.

(Observation, 2012-11-14)

Helene ställer en fråga som kopplar samman de erfarenheter som barnen har av det hon läser om och ett par av barnen ger liknande svar på frågan. Frågan som läraren ställer ger barnen utrymme för att uttrycka sina egna erfarenheter. Genom att läraren ställer en fråga som knyter an till barnens erfarenheter så finns det inget givet svar utan frågan öppnar upp för olika svar även om det i denna situation blir två liknande svar från barnen. Genom att lärarens fråga knyter an till barnens egna erfarenheter av det lästa har barnen möjlighet att gå bortanför berättelsens handling. När läraren ställer en fråga där handlingen ska kopplas samman med barnens erfarenheter aktiverar hon den bakgrundskunskap som barnen har om ämnet sedan tidigare. Genom att läraren handlar så kan barnen skapa en närmare relation till det lästa och ge barnen en bredare bild av innehållet.

\section{Läsa utan avbrott}

Vid högläsning läser läraren en berättelse eller ett avsnitt ur en berättelse utan avbrott. Vid dessa tillfällen introducerar läraren aktiviteten genom att hon läser titeln på boken eller rubriken på det avsnitt hon ska läsa för att därefter direkt börja läsa själva texten. Under tiden som läraren läser lyssnar barnen utan några avbrott. När läraren sedan avslutar läsningen övergår hon och barnen direkt till att arbeta med en helt annan aktivitet. Att läraren läser en berättelse utan avbrott förekommer när alla barnen i förskoleklassen närvarar, men det händer även när hälften av barnen är med.

Även barnen högläser berättelser utan avbrott och medan ett barn läser lyssnar övriga kamrater och läraren. Det här förekommer när barnen högläser en berättelse som de har haft i läxa under en vecka. Läxans syfte är att öva på att läsa de meningar som finns i boken. Det barn som ska läsa högt får själv välja om man ska sitta kvar på sin plats i den halvformade cirkeln eller sitta på den plats som läraren har, det vill säga mitt emot barnen. Tillsammans med läraren väljer varje barn den bok man vill ha $\mathrm{i}$ läxa och valet av bok sker utifrån hur mycket text det finns i den. Inför valet 
frågar läraren varje barn "Vill du ha en med mer, mindre eller samma text till nästa gång?” eller "Ska vi ta en med lite mer text till nästa gång?”. Böckerna finns från en mening och en bild per sida till några meningar och en bild per sida. En lärare berättar att när de introducerade att barnen skulle läsa högt så ville alla välja en bok med mycket text, men allteftersom har fler och fler förstått att de måste klara av att läsa de meningar som finns i boken. Vidare berättar läraren att eftersom det är barnen som har sista ordet för vilken text de ska ha i läxa så får barnen lära sig att själva fundera på vad de klarar av att läsa10. När ett barn har läst sin berättelse förekommer det att hon eller han visar de bilder som finns i boken. Bildvisningen sker på eget initiativ eller när någon kamrat ber att få se bilderna. Det inträffar att läraren stoppar bildvisningen genom att hon säger "Den som vill se bilderna kan istället låna boken”. Ibland får någon bild en kommentar från något barn, men för övrigt förekommer inga samtal om innehållet $\mathrm{i}$ berättelsen. Däremot brukar läraren fråga "Hur kändes det? eller "Har du läst boken många gånger hemma?” när ett barn läst klart sin berättelse. Till skillnad från när läraren högläser får ett barn som läst högt alltid en applåd.

I nedanstående sekvens kommer barnen in och sätter sig på sina respektive platser på golvet i grupprummet. De skrattar och småpratar med varandra. När Anton kommer in i rummet säger han högt:

\section{Exempel 7:12 Att läsa upp texten utan att läsa i boken}

Anton: Kolla, jag kan denna utantill!

Anton viftar med boken framför sig. Sedan "läser” han meningar utan att titta i boken. "Fia har en nöt. Fia har en bil. Fia har en” Ett par andra pojkar avbryter honom och menar att också de kan sina böcker utantill. Pojkarna rabblar sedan några meningar högt i munnen på varandra och skrattar.

(Observation, 2013-04-22)

Anton berättar för ett par kamrater att han kan säga meningarna i sin bok utan att läsa i den. De tre pojkarna återberättar ordagrant ur minnet och utan att ha texten framför sig de meningar som enligt dem själva står i deras respektive böcker. Då Anton berättar för ett par kamrater att han kan säga meningarna i sin bok utan att läsa i boken följer kamraterna efter och gör likadant. Möjligen är pojkarnas beteende ett uttryck för att de vill visa för varandra vad de kan. Flera av de ord som Anton säger återkommer i alla de meningar som han läser upp. När samma ord återkommer i den text som han läser har Anton möjlighet att känna igen orden. Han har även möjlighet att känna igen de orden i ett annat textsammanhang. Genom att Anton återberättar meningarna högt ur minnet har han troligen läst meningarna

10 Fältanteckning, informellt samtal 2013-04-22. 
många gånger hemma och därför kan de återkommande orden finnas lagrade som bilder. Detta kan innebära att Anton befinner sig i ett begränsat effektivt läsande. Det skulle även kunna vara så att han läser meningarna såsom en erfaren läsare gör, men med tanke på att han har en bok där meningarna består av att många samma ord är det mer sannolikt att de återkommande orden mer finns som ordbilder hos honom.

Genom att flera av orden återkommer i de meningar som Anton läser upp kan upprepningen av orden ses som stödstrukturer för att Anton ska ha möjlighet att känna igen orden. När han känner igen orden får han också rytm i läsningen och kan skapa sig en identitet som läsare.

När barnen läser den berättelse som de har haft i läxa sker det med olika hastigheter. Några läser alla eller några av orden långsamt eller hackigt medan andra läser texten snabbt och säkert.

Det är Pontus tur att läsa sin bok högt i nedanstående sekvens. Pontus har valt att läsa boken från den plats där han sitter. Det är nästan alldeles tyst $\mathrm{i}$ rummet och lärarens och kamraternas blickar är vända mot Pontus. Han slår upp första sidan i boken och börjar att läsa.

\section{Exempel 7:13 Läsa genom att koppla samman ljud och bokstav}

Pontus läser mening efter mening. Han läser flera ord i följd, men stannar ibland upp och ljudar tyst ett ord innan han högt säger vad det står. När han har läst färdigt klappar alla som har lyssnat händerna och Pontus tackar.

(Observation, 2013-04-22)

Pontus läser orden automatiskt, men använder emellanåt ljudningsstrategin för att läsa av ett ord. Han verkar läsa en bok där han får möjlighet att träna på att avkoda ord. När Pontus läser använder han ljudningsstrategin på ord som han inte direkt känner igen. Han förstår därmed att det finns ett samband mellan ljud och bokstav. Då Pontus läser de flesta av orden automatiskt blir läsningen sammanhängande vilket ger honom möjlighet att fokusera på berättelsens innehåll. Ibland använder han ljudningsstrategin för att läsa av ett ord vilket riktar hans uppmärksamhet mot att avkoda ordet och då står språkets form i fokus. Genom att avkoda ord ges Pontus möjlighet att träna på att automatisera ordavkodningen och få flyt i sin läsning. När barnen läser högt, men också då läraren högläser med eller utan avbrott, ges de barn som lyssnar en möjlighet att känna igen berättelsestrukturen. Då läraren frågar barnen om de vill ha mer, mindre eller samma mängd text i läxa hjälper läraren barnen att jämföra texterna med varandra. Genom att fundera över den textmängd som ska läsas får barnen möjlighet att reflektera över vad hon eller han klarar av att läsa och 
med det reflektera över sitt eget lärande. De frågor som läraren ställer till barnet efter det att hon eller han läst klart sin berättelse är frågor som relaterar till barnets känslor om att läsa boken högt och till att kontrollera antalet läsningar av berättelsen. Genom att läraren frågar "Har du läst boken många gånger hemma?” får hon veta hur mycket barnet övat på att läsa texten inför högläsningsstunden.

I ovanstående exempel verkar texten vara på en nivå som utmanar pojkens lärande när det gäller att avkoda ord vilket visar att övningen ligger inom pojkens närmaste utvecklingszon.

Någon gång förekommer det också att ett barn får högläsa en berättelse som denne inte har haft i läxa och därmed heller inte övat på att läsa innan framförandet.

I nedanstående sekvens har Ella och barnen i förskoleklassen morgonsamling. Barnen sitter i en ring på golvet och Ella sitter på en liten pall mellan två barn. Efter att ha sjungit en sång om veckans dagar tillsammans säger Ella:

\section{Exempel 7:14 Läsa med flyt}

Läraren: Jag tänkte att du Wilma som är bra på att läsa, kan du sätta dig här [pekar på sig själv] och läsa Alla barnen reser jorden runt för oss?

Ella håller upp framsidan på boken så att alla kan se den. Wilma nickar, reser sig och går fram till Ella. Ella reser sig från pallen och Wilma sätter sig på Ellas plats. Wilma får boken av Ella och slår upp första sidan. Det småpratas bland barnen. Wilma harklar sig och några av barnen skrattar. Alla tystnar och vänder sig mot Wilma. Wilma läser mening efter mening efter vartannat. Ibland betonar hon ord. Meningarna rimmar på varandra. Efter ett tag stannar hon upp. Hon håller upp boken framför ansiktet och visar en bild. Marcus och Anton kryper framåt mot Wilma.

Läraren: Nä, sitt kvar på era platser! Det är bättre att ni får titta i den sedan. Den finns där [pekar mot listen på whiteboardtavlan] och då kan ni se bilderna istället

Marcus: $\quad$ Kan jag läsa den då?

Ella nickar och barnen kryper tillbaka till sina respektive platser i ringen. Wilma fortsätter att läsa och under tiden som hon läser skrattar emellanåt några av barnen. När boken är färdigläst klappar barnen händerna och Wilma tackar. Hon lägger boken på golvet och går tillbaka till sin plats i ringen samtidigt som Ella tackar henne för läsandet.

(Observation, 2013-04-15)

Med motivet att Wilma är bra på att läsa ber Ella Wilma att högläsa en bok. När Wilma läser lyssnar kamraterna. Wilma läser med flyt och då det finns 
en bild i boken visar hon den så att alla kamraterna kan se. När Wilma visar bilden kryper Marcus och Anton emot henne, men Ella stoppar dem med hänvisning till att boken med dess bilder kommer att finnas tillgänglig efter det att Wilma läst färdigt den. Marcus undrar om han får läsa boken senare, vilket Ellen bekräftar. Wilma läser sedan vidare utan att visa några bilder och efter läsningen ger både kamraterna och Ella henne uppskattning för läsandet. Eftersom läraren uttrycker att Wilma är bra på att läsa och ber henne högläsa en bok verkar det som att läraren vet att Wilma klarar av att genomföra ett högläsningsmoment inför klassen. Då kamraterna lyssnar på Wilma när hon läser verkar det som att de är intresserade av det hon läser om. Wilma läser meningarna i berättelsen med flyt vilket visar att ordavkodningen är automatiserad. Genom att det flyter på när Wilma läser kan hon göra det möjligt för sig själv och kamraterna att koncentrera sig på textens budskap. Då några av barnen skrattar till emellanåt kan de ha uppfattat budskapet som Wilma vid det tillfället läste om. Wilma visar en bild ur boken på ett sätt som gör att samtliga kamrater kan se. Bilden verkar särskilt fånga Marcus och Antons intresse då de kryper närmare Wilma för att se den. Då Marcus frågar om han kan få läsa boken efter det att Wilma läst färdigt den verkar det som att Wilmas läsning inspirerar Marcus till att själv vilja läsa boken. Genom att läraren stoppar Marcus och Antons närmande mot Wilma och bilden bibehåller gruppen sin form. Möjligen grundar sig lärarens stopp av bildvisningen på att flera av barnen annars kan komma att flytta sig från sina platser eller så vill hon inte att Wilmas läsning ska komma av sig och med det kanske bli sönderhackad. Möjligen kan det även vara så att läraren vill att barnen ska skapa sig egna inre bilder av det som Wilma läser om. I ovanstående exempel riktas Wilmas uppmärksamhet mot flytet i läsningen vilket möjliggör för både Wilma och hennes kamrater att koncentrera sig på textens budskap och med detta kommer innehållet i berättelsen i fokus.

Det verkar som att läraren vet att Wilma kan läsa den bok som hon ber henne att läsa högt för alla, vilket tyder på att läraren har vetskap om Wilmas aktuella utvecklingszon och vad hon kan klara av att göra på egen hand. Wilma läser berättelsen med flyt och därmed likt såsom en erfaren läsare läser. Genom att läraren låter Wilma ta över berättelseläsningen utnyttjar hon den kompetens som finns i gruppen samtidigt som Wilma får möjlighet att öva och utvecklas på att läsa högt inför en grupp. De kamrater som lyssnar när Wilma läser kan få en kamrat i liknande ålder som de själva som läsmodell. 


\section{Sammanfattning}

I detta kapitel framkommer att läraren och barnen arbetar med den grammatiska koden på olika sätt. Ett centralt inslag är att de arbetar med språkets ljud i form av rim och fonem där fonemen också sätts samman med grafem. Genom att läraren och barnen arbetar med ord där de dels sätter samman ord och dels ger förklaringar till ord som de möter i olika sammanhang får barnen möjlighet att utöka sitt ordförråd. Att integrera språkets ljud, bokstäver och ord förekommer i aktiviteter där barnen ska skriva en fullständig mening. Ibland har barnen möjlighet att påverka innehållet i den mening som de ska skriva och ibland har de inte den möjligheten. En del barn deltar med intresse i de övningar de gör tillsammans med läraren medan andra barn gör muntligt motstånd mot dem. Motståndet grundar sig bland annat på att vissa barn har kunskap om en övnings innehåll sedan tidigare. Det förekommer också att något barn föreslår en förändring av en övning så att den blir mer utmanande, men att läraren inte anammar detta på grund av att andra barn i förskoleklassen inte har den kompetens som behövs för att lösa uppgiften.

I detta kapitel framkommer även att både läraren och barnen högläser berättelser. När läraren läser kan hon göra avbrott för frågor om berättelsens handling, men hon kan också ställa frågor som går bortom själva handlingen genom att hon exempelvis knyter textens innehåll till barnens egna erfarenheter. Genom lärarens frågor kan barnen få syn på strategier som hjälper dem att förstå texters innehåll. Såväl läraren som barnen läser berättelser utan avbrott. Vissa barn läser med hjälp av ljudningsstrategin medan andra barn läser på ett automatiserat sätt. De texter som barnen läser har olika svårighetsgrader, vilket möjliggör en läsning utifrån vars och ens förutsättningar och behov. Sammantaget gör dock oftast samtliga barn i förskoleklassen samma skriftspråkliga uppgifter vilket förhindrar en utvecklad individanpassning. 


\section{Diskussion}

I följande kapitel diskuteras inledningsvis genomförandet av denna studie vilken handlar om samtal och skriftspråklighet i förskoleklassen. Därefter diskuteras resultaten i relation till tidigare forskning, studiens teoretiska utgångspunkter och forskningsfrågorna. Syftet med studien har varit att bidra med kunskaper om förskoleklassens verksamhet med fokus på lärares och barns handlingar i samtals- och skriftspråksorienterade lärarledda aktiviteter. Med utgångspunkt i syftet formulerades följande forskningsfrågor: Vad händer i mötet mellan läraren och barnen i dessa aktiviteter? Vilka förutsättningar för barns samtalande och skriftspråkande skapas i interaktion mellan läraren och barnen i de lärarledda aktiviteterna? Kapitlet avslutas med förslag till fortsatt forskning.

\section{Metodiska reflektioner}

Den här studien avgränsas till att handla om samtals- och skriftspråksorienterade lärarledda aktiviteter i förskoleklass. Studien ger således inte en heltäckande bild av den verksamhet som förekommer i de studerade förskoleklasserna. De lärarledda samtals- och skriftspråksorienterade aktiviteter som studeras äger rum vid samlingar och gruppmoment. När det står fri lek på schemat så sker den däremot för det mesta utan lärarens aktiva stöd och ledning. Även om samtliga aktiviteter i grunden är lärarledda handlar läraren följaktligen på olika sätt under dagen. Som tidigare beskrivits består det insamlade datamaterialet framför allt av delvis deltagande observationer där fältanteckningar skrivits för att dokumentera dessa. Jag har även samlat in dokument från fältet och haft informella samtal med både lärarna och barnen (se vidare kapitel 4). Vid analysen av datamaterialet gjordes en avgränsning och ljuset riktades mot de lärarledda aktiviteter som pågår vid samling eller gruppmoment. Detta innebär att datamaterial från exempelvis fri lek inte finns med i föreliggande studie även om den aktiviteten också kan innehålla inslag av skriftspråklighet och samtal.

Delvis deltagande observationer/fältanteckningar valdes som den mest lämpliga metoden för att besvara studiens syfte, men här hade videokamera med ljudupptagning och/eller enbart ljudupptagning kunnat vara ett komplement till att skriva fältanteckningar. En videoinspelning med ljudupptagning har fördelen att forskaren i efterhand kan gå tillbaka och studera situationen. Det finns också nackdelar, till exempel att det kan ske 
störningar i ljudupptagningen eller att rummets form och möblering sätter begräsningar för vad som är möjligt att spela in (Heikkilä \& Sahlström, 2003; Sparrman, 2005). Videoinspelningar fångar dessutom bara en avgränsad del av verksamheten och genom att använda fältanteckningar kunde en helhetsbild av verksamheten lättare fångas.

När studien inleddes var utgångspunkten att studera lärares och barns handlingar i förskoleklassen. Studien utgick inledningsvis från ett brett fokus vilket avgjorde valet av fältanteckningar som dokumentationsmetod istället för videoinspelningar. Jag som observatör med anteckningsblocket och pennan i hand kunde snabbt och enkelt förflytta mig mellan olika aktiviteter utomhus och mellan olika rum inomhus. Även om jag efter ett tag bestämde mig för att vara kvar i ett rum och observera det som hände, istället för att gå mellan olika rum, så framstod inte videoinspelning som ett alternativ utan jag upplevde att fältanteckningar var ett bra sätt att samla in data på.

Att observera och skriva fältanteckningar innebär att jag som forskare väljer ut ett specifikt moment att titta på och med det följer ett bortfall av andra moment. Vad som avgjorde mitt val av moment att observera var till exempel att jag redan innan en aktivitet startade bestämde mig för att vara i ett visst rum. Därigenom fick jag möjlighet att observera läraren och barnen en längre stund och se hela processer. Det innebar dock att data från andra händelser vid samma tidpunkt $\mathrm{i}$ ett annat rum gick förlorade. Hammersley och Atkinson (2007) menar emellertid att man som forskare är i behov av att avgränsa sig. De menar vidare att forskaren måste göra en kompromiss och välja mellan djup eller bredd då observation på flera platser medför mindre tid på var och en av dessa.

Att hinna med att anteckna och med hjälp av minnet beskriva det som observerats vid en aktivitet är en problematik som Fangen (2005) lyfter fram. Hon menar att i praktiken kan forskaren inte anteckna alla intryck eftersom det är svårt att komma ihåg mer än en begränsad mängd detaljer. Ett sätt att ändå få med så många detaljer som möjligt är att skriva fältanteckningar i nära anslutning till den aktivitet som observerats (Fangen, 2005). Jag valde att skriva mina fältanteckningar under tiden som jag observerade en aktivitet. Detta för att på så sätt försöka få med så många detaljer som möjligt, men precis som Fangen uttrycker finns det saker man som observatör missar, vilket också jag gjorde.

Sammantaget anser jag att det insamlade datamaterialet är rikt då det består av många observationer och informella samtal där fältanteckningar skrivits och tillsammans ger de en helhetsbild över de aktiviteter som ingår i denna studie. 
När det gäller situationernas autenticitet är det troligt att min närvaro, i begränsad grad, påverkat de situationer som studerats (se vidare kapitel 4). För att verifiera autenticiteten hade deltagarna kunnat få möjlighet att själva bedöma i vilken utsträckning de påverkats av observationerna (Granström, 2004), vilket jag i efterhand kan se att de borde fått möjlighet att tala om. Detta hade exempelvis kunnat ske genom att deltagarna fått möjlighet att berätta om sina upplevelser i uppföljande intervjuer eller att de fått redogöra för stunder under observationerna då de kände sig påverkade eller störda av mig som observatör.

Utifrån ett etiskt perspektiv hade både vårdnadshavare och barn kunnat ges större möjligheter att påverka sitt samtycke till att delta i studien genom att ett missivbrev med svarstalong begärts in. I efterhand kan jag se att det hade varit bra om denna möjlighet getts för att försäkra mig om att alla deltagare var villiga att delta i studien. En av UNICEFs (2009) och Barnkonventionens grundläggande principer handlar om barnets rätt att uttrycka sin mening och få den respekterad. Skelton (2008) menar att i relation till vad som lyfts fram i denna konvention är barn kompetenta att själva bestämma över om de vill delta i en forskningsstudie eller inte och inte som idag, att vårdnadshavarna tar det slutgiltiga beslutet. Vid mina besök försökte jag ändå läsa av barnens kroppsspråk när jag närmade mig dem eller befann mig nära de aktiviteter som de höll på med. Detta för att få en vägledning om min närvaro var önskad eller inte. Ofta frågade jag också om det var okej att jag satte mig hos dem en stund, vilket är ett tillvägagångssätt som Alderson (1995) rekommenderar för att ta reda på barnens upplevelse av forskarens närvaro.

\section{Studiens resultat}

\section{Förskoleklassens sammanhang}

Förskolan och skolan har traditionellt haft olika syn på omsorg, fostran, kunskap och lärande. I förskolan har arbetet varit fokuserat på lek, skapande, omvårdnad och omsorg, samt barns eget utforskande i temainriktade projekt, medan skolan mer inriktat sig på ett långsiktigt, systematiskt och strukturerat lärande. Förskolan har således haft en mer socialt inriktad verksamhet i förhållande till grundskolans mer kunskapsinriktade verksamhet (Proposition 1997/98:6; SOU 2010:67). När staten införde förskoleklassen som en egen skolform var intentionen att en ny praktik och ett nytt pedagogiskt förhållningssätt skulle utvecklas. Förskoleklassen skulle koppla samman verksamheten i förskolan, grundskolan och fritidshemmet (Skolverket, 2001; SOU 1997:21). Förskoleklassen skulle därmed fungera som en bro mellan förskolans och skolans pedagogiska traditioner (Proposition, 1997/98:6). Denna studie 
pekar dock, i enlighet med tidigare studier (se exempelvis Pérez Prieto et al., 2003; Skolverket, 2001), på att förskoleklassen mer anpassat sig efter skolans traditionella sätt att organisera och strukturera undervisningen. Dagarna i studiens förskoleklasser är till exempel schemalagda i olika tidsstyrda pass. Passen består av olika ämnen och inga temainriktade projekt förekommer. Ett annat exempel är att läraren har det största talutrymmet i klassrummet, och där de samtal som förs mellan läraren och barnen är strukturerade enligt ett för skolsamtal vanligt mönster som innebär att när ett barn pratat färdigt så är det återigen lärarens tur att tala (jfr exempelvis Sahlström, 2008; Sinclair \& Coulthard, 1975).

Förskoleklassen har sin verksamhet inom grundskolans lokaler, vilket man menade från statens sida skulle underlätta implementeringen av förskolepedagogiken (Proposition 1997/98:6; Proposition 1997/98:94). Genom att förskoleklassen befinner sig inom skolans ram hamnar lärarna som arbetar i förskoleklassen i minoritet på skolan och i arbetslaget, vilket möjligen kan innebära en svårighet när det gäller att få gehör för att bedriva en mer förskolepedagogiskt inriktad verksamhet i förskoleklassen. Resultatet av föreliggande studie visar att lärarna mer förhåller sig till en traditionell skolstruktur i sina handlingar. Lärarnas handlingar kan därför förstås som delar av kontexter och kontextuella förutsättningar. Handlingarna "ingår i, skapar och återskapar kontexter. Delar och helheter definierar varandra, och kontexten kan ses som det som väver samman en social praktik eller verksamhet och gör den till en identifierbar helhet” (Säljö, 2000, s. 135). Människors handlingar bidrar till att omskapa eller återskapa den verksamhet som de utförs i (Säljö, 2000). Lärarna som ingår i studien befinner sig således i en skoltradition som sätter vissa ramar för förskoleklassverksamheten.

\section{Lika för alla}

Inom det sociokulturella perspektivet anses både interaktion och kommunikation betydelsefulla för att förstå lärande och utveckling på såväl kollektiv som individuell nivå (Säljö, 2000). Samtalen i denna studie kan, i likhet med annan forskning (jfr Chapin \& O'Connor, 2007; Mehan, 1979; Mercer, 1995; Sahlström, 2008; Sinclair \& Coulthard, 1975), beskrivas som något som huvudsakligen sker mellan läraren och ett barn i taget. Läraren ställer en fråga och ett barn får ordet, antingen genom handuppräckning (exempel 6:7), eller i turordning efter exempelvis hur barnen sitter i samlingsringen (exempel 6:6), barnet svarar och läraren värderar eller vidareutvecklar barnets svar (se exempelvis exempel 6:4; exempel 6:1). Både samtalsstrukturen IRE och IRF förekommer därmed i studiens klassrum (jfr Mehan, 1979; Sahlström, 2008; Sinclair \& Coulthard, 1975). När läraren ger respons på barnets svar genom att värdera svaret är det 
enligt Hargreaves, McCaluum och Gipps (2000) en verbal handling där läraren visar sin uppskattning. När läraren ger respons på barnets svar förekommer även att läraren upprepar det som barnet sagt (exempel 6:5), vilket enligt Mercer (1995) är en samtalshandling i form av en "talk moves" som syftar till att uppmärksamma samtliga barn på svaret för att därigenom stödja deras lärande. Denna respons, där läraren upprepar barnets svar, benämner Chapin och O'Connor (2007) för "revoicing”. De menar att när läraren repeterar ett barns svar så är det en samtalshandling som har potential att höja kvalitén på diskussionen. När barn uttrycker sig mångordigt vid sin tur att prata avgränsar läraren samtalet och när barn uttrycker sig fåordigt ber läraren om mer utförliga svar då hon stödjer upp med följdfrågor (exempel 6:2; exempel 6:3). Läraren försöker på så sätt göra samtliga barn delaktiga i samtalen och ge varje barn ungefär lika stort talutrymme. Samtalen i studien kan på så sätt sägas utgå från ett deltagande som är "rättvist” fördelat i meningen att alla får komma till tals (jfr Chapin \& O'Connor, 2007). Den demokratiska potential som ligger i att fördela talutrymmet lika för alla barn kan samtidigt innebära ett hinder för att utveckla det dialogiska klassrummet (jfr Dysthe, 1996). Att försöka göra samtliga barn delaktiga i samtalen med ungefär lika stort utrymme kan vara ett sätt för läraren att hantera den utmaning det innebär att få med alla barn så att ingen tappar orken eller koncentrationen. Ett barn som känner sig delaktig i ett samtal ges större möjligheter att hålla koncentrationen längre än barn som inte upplever detta. Läraren står följaktligen ständigt inför utmaningar där hon behöver göra olika avvägningar för att samtliga barn ska kunna fokusera på det samtal och den aktivitet som pågår.

Att läraren utgår från ett förhållningssätt där strävan är att talutrymmet ska vara lika för alla barn innebär att barn som ofta sitter tysta också får möjlighet att delta i samtalet och därmed utvecklas språkligt. Ett sådant förhållningssätt kan även göra att barnen vet att det någon gång blir deras tur att prata inför gruppen. En konsekvens verkar emellertid vara att möjligheten till mer fördjupade samtal begränsas. När samtliga barn ges utrymme att svara begränsas samtalens innehåll och också möjligheten för det enskilda barnet att utveckla sina tankar, där läraren men också kamraterna kan ställa följdfrågor som expanderar eller fördjupar samtalet. Att barn ges möjligheten till fördjupande diskussioner och får träna på att argumentera är viktigt för att dessa förmågor ska utvecklas. Att ge plats åt kamraternas frågor och inlägg är därför av betydelse. I ett klassrum där ett dialogiskt förhållningssätt är i fokus är kamraternas yttranden centrala (Dysthe, 1996; Wells \& Arauz, 2006). Samtal som är på väg mot en mer dialogisk riktning kännetecknas enligt Wells och Arauz (2006) av att läraren ställer öppna frågor vilka barnen har flera möjliga svar på och där 
de uppmuntras att göra inlägg på kamraternas bidrag. I föreliggande studie får barnen vara delaktiga i samtalen genom att läraren inleder med att ställa en öppen fråga till barnen. Som ovan beskrivits sker sedan emellertid kommunikationen mestadels mellan läraren och ett barn i taget och därmed kommer lärarens uppmuntran om att låta andra barn göra inlägg på sina kamraters bidrag i skymundan. Att skapa en lärande samvaro mellan barnen där läraren inte alltid behöver vara navet ser jag som ett sätt att ge barnen möjlighet att delta i fördjupande diskussioner. Ur ett sociokulturellt perspektiv är det inte bara den vuxne som kan vara vägledare utan det kan också vara mer kunniga kamrater som vägleder den mindre kompetente (Vygotskij, 1978). I fokus för de samtal som förs i de studerade verksamheterna står således att samtliga barn ska få prata inför gruppen och tala lika mycket, vilket verkar ske på bekostnad av att kunna utveckla ett mer fördjupat samtalsinnehåll.

Arbetet med skriftspråket genomsyras till stor del av att alla barn gör samma övningar oavsett deras tidigare kunskaper, vad gäller till exempel förmågan att rimma på ord (exempel 7:2). När läraren organiserar de lärarledda aktiviteterna utifrån att alla barn ska göra lika kommer läroplanens skrivelse om en likvärdig utbildning i skymundan, i meningen att undervisningen ska anpassas till varje elevs förutsättningar och behov (jfr Skolinspektionen, 2015:03). En möjlig förklaring till att barnen gör samma övningar kan vara att det inte finns tid till att kartlägga varje barns förmågor och kunskaper. I Skolinspektionens (2015:03) kvalitetsgranskningsrapport framkommer också ett behov av att skapa förutsättningar för planering, uppföljning, utvärdering och reflektion för de lärare som arbetar i förskoleklass.

De lärarledda aktiviteterna genomförs i helklass eller halvklass och det är sällan som andra gruppkonstellationer förekommer. Under dessa aktiviteter ges samtliga barn möjlighet att delta i samtalen. Alla får ungefär lika stort talutrymme och får till stora delar göra samma skriftspråkliga övningar oavsett tidigare kunskaper. Det innebär att utrymmet för det enskilda barnet begränsas när undervisningen organiseras som det gör i studien. Ur ett sociokulturellt perspektiv handlar lärande om ett aktivt deltagande där individer ger och tar i samverkan med varandra. Att delta i aktiviteter är därför en nödvändighet för människors lärande och utveckling (Säljö, 2013). 


\section{Högläsning - att röra sig i texter på olika sätt}

Forskning visar att det finns ett starkt stöd för att högläsning och samtal om texter har en betydelsefull roll för ett barns språkutveckling (Adams, 1990; Baker et al., 2013; Liberg, 2003; 2007b; Leppänen et al., 2005; Snow et al., 1998). I studiens förskoleklasser förekommer högläsning av berättelser och samtal om texterna. Intressant att notera är att det inte förekommer läsning av några andra textgenrer såsom faktaböcker. Vanligen utgör högläsningen ett fristående inslag i undervisningen (jfr Skoog, 2012), men den kan även ha en anknytning till det som läraren och barnen för övrigt arbetar med i förskoleklassen (jfr Cochran-Smith, 1984). Ett exempel på detta är när läraren läser en berättelse om Trulle och Rim Tim i samband med en rimövning (exempel 7:1).

Vid högläsningen gör läraren ofta avbrott i läsandet för att ställa frågor om texten till barnen. Några av de literacyhändelser som då framträder är att läraren och barnen samtalar om sådant som kan knytas till berättelsens handling (exempel 7:10) eller så går samtalet bortom den direkta handlingen (exempel 7:11). När det gäller ett barns förmåga att förstå texter framhävs betydelsen av att kunna röra sig i en text på olika sätt. Liberg (2014) menar att det handlar om att kunna röra sig i texter både på ett intratextuellt och intertextuellt sätt. Båda dessa textrörligheter förekommer i samband med att läraren högläser berättelser (exempel 7:10; exempel 7:11). En intratextuell textrörlighet handlar bland annat om att kunna se samband mellan olika inslag och dra enkla slutsatser, vilket framkommer att läraren och barnen gör när de samtalar om sådant som kan knytas till berättelsens handling. Att röra sig i texter på ett intertextuellt sätt handlar exempelvis om att knyta an det lästa till egna erfarenheter, vilket läraren och barnen gör då de samtalar om sådant som går bortom den direkta handlingen.

Enligt Wood et al. (1976) ska det stöd en vuxen ger vara i relation till barnens kompetensnivå. När läraren ställer frågor som syftar till att barnen exempelvis sammanfattar eller förutspår innehållet i berättelsen och där frågorna på så sätt kan knytas till berättelsens handling, kan frågorna ses som stödstrukturer för att ge barnen möjlighet att skapa mening och förståelse för den lästa texten (exempel 7:10). Vikten av att barn behöver få stöd med att utveckla förståelsestrategier såsom att sammanfatta och förutspå handlingen förordas av flera forskare (se exempelvis Palincsar \& Brown, 1984; Pilonieta \& Medina, 2009).

Det förekommer även högläsning av berättelser utan avbrott för frågor. När ett sådant läsande sker verkar det ibland som att barn inte behöver stödstrukturer för att mening och förståelse för en text ska skapas. När till exempel ett av barnen högläser en berättelse med flyt möjliggör det både för läsaren själv och för kamraterna som lyssnar att koncentrera sig på 
textens budskap. Genom att barn emellanåt skrattar till under tiden som texten läses ges en antydan om att de skapat förståelse för textens budskap (exempel 7:14). Förståelse för en text kan således skapas både med och utan stödstrukturer.

\section{Skriva en mening - styrt och fritt}

Det finns forskare som uttrycker att när det formella skriftspråkslärandet tar vid bör skrivandet stå i fokus istället för läsandet. När ett barn skriver utgår barnet från ord som hon eller han själv valt till skillnad från när barnet läser då någon annan valt orden (Björk \& Liberg, 2004: Liberg, 1990). Det skrivande som sker i förskoleklassen visar att när barnen ska skriva en mening så förekommer både ett styrt och ett friare skrivande. Läraren styr vad barnen ska skriva genom att hon skriver en mening på whiteboardtavlan vilken samtliga barn sedan skriver av i sina arbetsböcker (exempel 7:8). Men barnen skriver även på ett friare sätt då de utifrån ett bestämt innehåll på egen hand formulerar en mening vilken sedan är tänkt att läsas av personer som är närstående till barnen (exempel 7:9). Barnen ges möjlighet att arbeta med att skriva och uttrycka ett innehåll som de själva har valt samtidigt som de också utforskar skriftspråkets regler (jfr Eriksen Hagtvet \& Pálsdóttir, 1993; Skoog, 2012). Genom att texten är tänkt att läsas av andra kommer skrivandet in i ett sammanhang som har ett vidare syfte än att bara träna skrivning. Det blir således ett undervisningssammanhang där språkets innehåll, form och funktion är i ett visst samspel med varandra. Både en formaliserad och en funktionaliserad undervisning förekommer därmed, vilket är något som Liberg (2008) rekommenderar. I det fria skrivandet hanterar barnen sålunda innehållsaspekter såväl som formaspekter parallellt (jfr Eriksen Hagtvet \& Pálsdóttir, 1993).

När det gäller att försöka förstå och förklara lärande ligger fokus ur ett sociokulturellt perspektiv på hur individer handlar vid olika slags aktiviteter och vilka erfarenheter de då gör (Säljö, 2013). Ett styrt respektive friare skrivande skapar olika förutsättningar för barns deltagande i aktiviteterna. Ett styrt skrivande kan mer sägas begränsa barnens aktiva deltagande då det är läraren som bestämmer vilken mening barnen ska uttrycka i skrift jämfört med ett friare skrivande som möjliggör för ett mer aktivt deltagande då barnen själva väljer med vilka ord de ska skriva sin mening.

När barnen skriver sina meningar kan de ta hjälp av varandra när de inte vet hur ett ord stavas. Någon kamrat som har förstått sambandet mellan ljud och bokstav förklarar då hur ett ord stavas med hjälp av ljudenlig stavning, vilket tyder på att barnet befinner sig i ett grammatiskt skrivande enligt Libergs (1990; 2006) definition. Läraren kan också hjälpa barnen genom att skriva ner den mening som respektive barn formulerat på en papperslapp, vilken barnet sedan skriver av. Papperslappen kallas av 
läraren och barnen för fusklapp. I resultatavsnittet framkommer att Alicia får en så kallad fusklapp av läraren med den mening som hon har berättat för läraren att hon vill skriva (exempel 7:9). Alicia, som är aktivt närvarande under tiden som läraren skriver hennes mening, kan sedan sägas imitera det som läraren skrivit, vilket Vygotskij (1978) ser som ett återskapande eftersom det sker inom den närmaste utvecklingszonen. Att ha en modell att skriva utifrån blir på så sätt en stödstruktur som möjliggör för Alicia att själv skriva sin mening. Papperslappen med den nedskrivna meningen, vilken ur ett sociokulturellt perspektiv kan betraktas som ett redskap för lärandet, benämns i verksamheten som ett fusk. Lärande ur ett sociokulturellt perspektiv handlar om hur en individ tar till sig och gör kunskapen till sin egen, det vill säga appropierar de kunskaper individen möter. Förståelse är något som konstrueras i den sociala praktiken där interaktionen mellan individen och kollektivet är centralt. En individ befinner sig hela tiden under utveckling och förändring. (Säljö, 2000; 2013). I situationen är Alicia aktivt deltagande och får möjlighet att börja appropiera kunskap med stöd av redskap som gör att hon får möjlighet att gradvis utveckla sin förmåga att skriva på ett vedertaget sätt.

Barnen som ingår i studien uppmuntras sällan att skriva i mer fria former vilket kan ställas i relation till forskning som visar att många barn själva väljer att närma sig skriftspråket genom skrivandet (Björk \& Liberg, 2004; Liberg, 2006). När barnen skriver utgår de från ord som de själva har valt, till skillnad från när de läser då någon annan valt orden. Barnen deltar därför mer aktivt i processen när de skriver än när de läser (Björk \& Liberg, 2004; Liberg, 1990).

\section{En pågående upprepning}

Studiens resultat visar att de lärarledda aktiviteterna i förskoleklassen till stora delar utgår från att alla barn ska göra lika, vilket innebär att undervisningen blir lika för samtliga barn. Läraren verkar på så sätt organisera undervisningen efter vad Dahllöf $(1967 ; 2002)$ och Lundgren (1972; 1989) benämner som styrgrupp. I styrgruppen ingår inte de barn som är bäst i klassen och inte heller de som lär sig långsammast. Det är istället den grupp av barn som lär sig något snabbare än de som lär sig långsammast.

Under morgonsamlingarna brukar läraren och barnen samtala med varandra om den kommande helgens händelser eller samtala om det som har hänt under den gånga helgen. Det är ett samtalsinnehåll som återkommer och upprepas under veckorna i förskoleklassen vilket en del barn gör motstånd emot. I studien framkommer också att läraren och barnen arbetar med skriftspråkliga upprepningar och att dessa upprepningar förekommer i såväl undervisningssituationen som mellan olika skolformer 
(se avsnittet om den grammatiska koden). När det som ska läras återkommer kan det ge barnen en känsla av igenkänning och därigenom en viss trygghet genom att de inte utsätts för något som är svårt eller utmanande. Vidare framkommer att arbetet med rim (exempel 7:2) och sammansatta ord (7:6) väcker en viss irritation hos några av barnen, då de redan behärskar dessa moment. De barn som exempelvis redan kan rimma gör motstånd mot att delta i övningarna vilket kan ses som att barnen söker efter att bli utmanade i sitt lärande. Detta kan ställas i relation till den närmaste utvecklingszonen vilket är ett centralt begrepp inom det sociokulturella perspektivet. Vygotskij (1978; 1934/2010) menar att det som ett barn ska lära sig inte bör ligga i zonen för vad hon eller han redan behärskar, utan individens potentiella utveckling ska vara i fokus och på så sätt blir individen utmanad i sitt lärande. För barn som inte kan rimma blir däremot arbetet med att rimma en utmaning under förutsättning att det sker inom barnets potentiella utvecklingszon. Vad barnet kan uppnå i samarbete med den vuxnes stöd eller mer kunniga kamraters stöd är avgörande. Vygotskij (1978) uttrycker det som "... what a child can do with assistance today she will be able to do by herself tomorrow" (Vygotskij, 1978, s. 87). Föreliggande studie visar således att i arbetet med rim eller sammansatta ord får inte alltid barn det stöd och/eller de utmaningar de behöver för att kunna utvecklas så långt som möjligt (jfr Skolverket, 2015). Skollagens skrivelse om att varje elev ska ges möjlighet att nå så långt som möjligt i sin kunskapsutveckling (SFS 2010:800) blir i dessa situationer inte uppfylld.

När övningar upprepas stimuleras de barn som redan kan det som ska läras i övningarna inte vidare i sitt lärande. För att ge barn möjlighet till fortsatt utveckling behövs en progression i lärandet. Upprepning av det som barnen redan kan när de kommer till förskoleklassen innebär att deras erfarenheter sedan tidigare inte tas tillvara. Inom det sociokulturella perspektivet ses inte lärandet som något som bara sker i skolan (Säljö, 2000; 2013). Studier (se exempelvis Björklund, 2008; Heath, 1983; Scribner \& Cole, 1981) inom forskningsinriktningar som emergent literacy och early childhood literacy visar att många barn utforskar skriftspråket i samspel med andra människor långt innan den formella läs- och skrivinlärningen tar vid. Utforskandet av till exempel texter och bilder förekommer inte vid ett speciellt tillfälle eller på en särskild plats utan i de vardagliga sammanhang som barnet befinner sig i. Denna studie, liksom tidigare studier (jfr Fast, 2007; Skoog, 2012) visar att det arbete som sker i förskoleklassen således inte alltid bygger vidare på de kunskaper som barnen har med sig från tidigare, till exempel från förskolan.

En möjlig förklaring till varför det förekommer upprepningar i förskoleklassen kan vara att det innehåll som aktiviteterna har grundar sig på traditioner där man i många år gjort på ett liknande sätt. Rim har 
exempelvis alltid varit ett självklart inslag i förskoleklassens verksamhet. Undervisningen styrs av förväntningar på att rim ska ingå och då undervisar lärarna det oavsett om vissa barn har kunskap om rim sedan tidigare eller ej. Att vara i det som är känt kan också skapa en känsla av trygghet och säkerhet hos läraren. En ytterligare förklaring till varför det förekommer upprepningar i förskoleklassen kan vara att det i skolsammanhang är vanligt att gruppera barnen efter antingen helklass eller halvklass. En sådan organisation kan göra det möjligt för läraren att ha kontroll över vad alla barn gör, vilket kan vara svårare för läraren om barnen arbetar i mindre sammanhang (jfr Granström, 2003).

Som tidigare beskrivits pekar denna studie mot en förskoleklass som mer anpassat sig efter skolans traditionella sätt att organisera och strukturera undervisningen, vilket kan ställas i relation till att flertalet av de lärare som ingår i studien är förskollärare. Ur ett sociokulturellt perspektiv handlar en individ utifrån sina egna kunskaper och erfarenheter och vad man bedömer att omgivningen vill eller kräver i en bestämd verksamhet (Säljö 2000; 2013; Wertsch, 1985). Individens handlingar finns i den sociala praktiken och tänkande, kommunikation och fysiska handlingar är förbundna till situationen, det vill säga är situerade i denna kontext (Säljö, 2000). Lärarnas kunskaper har sålunda sina rötter i förskolans pedagogik, men det förefaller som att de väljer bort förskolans arbetssätt mot vad de möjligen bedömer att skolan förväntar sig av förskoleklassens verksamhet.

Vikten av fonologisk medvetenhet, särskilt fonemisk medvetenhet, lyfts i forskning fram som en betydelsefull faktor för barns skriftspråkstillägnande (Adams, 1990; Bus \& van Ijzendoorn, 1999; Ehri et al., 2001; Gillon, 2004; Liberg, 2003; Lundberg et al., 2012). Föreliggande studie visar att literacyhändelser där läraren och barnen gör olika rimövningar eller på olika sätt arbetar med fonemen i vårt talade språk utgör centrala inslag i förskoleklassens verksamhet. I denna studie framkommer också att läraren och barnen gör övningar där de sammankopplar fonem och grafem. Övningar som kopplar samman fonem och grafem bidrar mer effektivt till barns läsutveckling jämfört med övningar som bara fokuserar på medvetenhet om fonem (Bradley \& Bryant, 1983; Bus \& van Ijzendoorn, 1999; Hatcher et.al., 1994; Liberg, 2003; National Reading Panel, 2000). Av tradition är detta övningar som även förekommer i årskurs 1 och som också återkommer i läromedel för årskurs 1. Att på olika sätt göra barn uppmärksamma på fonem och grafem och kopplingen dem emellan är av betydelse för att ge barn möjlighet att knäcka den alfabetiska koden. Inte desto mindre är det väsentligt att som lärare i förskoleklass och årskurs 1 stämma av vad barnen kan när de börjar respektive skolform så att en progression kan ske istället för en upprepning av det som barnen redan kan. 
I Skoogs (2012) studie, som följer barn från förskoleklass till årskurs 1, visas att det sker en upprepning då barn under årskurs 1 får möta samma typ av uppgifter som de arbetat med i förskoleklassen men med den skillnaden att arbetet med bokstäver i ettan innehåller fler moment.

Sammanfattningsvis visar studien att lärarens och barnens handlingar i de samtals- och skriftspråksorienterade lärarledda aktiviteterna i förskoleklassen har en skolinriktad prägel och att alla barn till stora delar gör samma övningar. Läraren och barnen rör sig i höglästa berättelser på ett såväl intratextuellt som intertextuellt sätt och när de tillsammans arbetar med att skriva så förekommer både ett styrt och ett friare skrivande. Lärarens och barnens handlingar under de samtals- och skriftspråksorienterade lärarledda aktiviteterna visar dessutom att det förekommer en viss upprepning av ett innehåll som vissa barn har kunskap och erfarenhet av sedan tidigare, till exempel från förskolan.

Genom att uppmärksamma lärares och barns handlingar kan studien bidra med kunskaper om betydelsen av att ta tillvara barns tidigare erfarenheter så att varje barn ges möjlighet att nå så långt som möjligt i sin kunskapsutveckling. För att detta ska kunna ske behöver läraren ta mer hänsyn till det enskilda barnets förutsättningar och behov och därigenom kan en likvärdig utbildning i högre grad komma i fokus. De lärarledda aktiviteterna kan då inte utgå från att alla barn gör lika utan behöver i högre grad varieras både vad gäller innehåll och form. När lärarens förväntningar utgår från barnets förutsättningar och behov ökar sannolikt barnets intresse och motivation för det som ska läras. Då skulle även det motstånd som vissa barn visar när de ska göra övningar som de säger sig redan kunna, troligtvis förekomma i mindre omfattning. Kanske kan skapandet av undervisningssammanhang där det råder ett samspel mellan språkets innehåll, form och funktion tjäna som utgångspunkt för läraren (jfr Liberg, 2008). Centralt blir då att arbetet med skriftspråket är anpassat till barnens olika erfarenheter samt fyller en funktion för barnen, men också vid behov studeras separat och strukturerat. Detta sätt att skapa undervisningssammanhang kan, som jag ser det, göra att undervisning som organiseras efter en så kallad styrgrupp begränsas (jfr Dahllöf, 1967; 2002; Lundgren, 1972; 1989).

I den senaste läroplanen (Skolverket, 2016) finns nu ett avsnitt om förskoleklassens syfte och centrala innehåll vilket inte funnits i tidigare läroplaner. Förhoppningsvis kan införandet av ett sådant avsnitt medföra att lärare som undervisar i förskoleklass nu får ett tydligare stöd i vad de förväntas undervisa om under förskoleklassåret. Det kan även bli ett stöd för att lärarnas diskussioner om undervisningspraktiken förstärks då de nu har en gemensam skrivelse att utgå ifrån. En förutsättning för gemensamma diskussioner är dock att lärare som undervisar i förskoleklass får tid till att samverka med kolleger inom samma praktik. De behöver också få tid till 
att samverka med kollegor i förskolan och årskurs 1 (se exempelvis Gannerud \& Rönnerman, 2006; Sandberg, 2012; Skolinspektionen, 2015:03).

\section{Förslag till fortsatt forskning}

Denna studie visar bland annat att de lärarledda aktiviteter som förekommer i förskoleklassen inte alltid bygger vidare på det som barnen redan kan. Med utgångspunkt i detta och med tanke på att datamaterial samlats in från barnens nästkommande verksamhet vore det intressant att analysera vad som händer i årskurs 1. Tidigare studier (se exempelvis Fast, 2007; Skoog, 2012) visar att övningar från förskoleklassen många gånger upprepas i årskurs 1. I relation till denna forskning vore det intressant att se åt vilket håll mitt insamlade datamaterial pekar.

Ett annat förslag till forskning är att studera tidigare eller senare övergångar. Övergången från förskola till skola (jfr Fast, 2007) eller från årskurs 3 till årskurs 4 är exempel på sådana övergångar. Vetenskapsrådet (2015) betonar att det behövs mer forskning som inriktar sig mot yngre elevers läs- och skrivundervisning. Vad händer inom läs- och skrivundervisningen vid dessa olika övergångar? Sker det en upprepning eller finns det en progression i lärandet? Vilka likheter och skillnader framträder vid dessa övergångar med övergången från förskoleklass till årskurs 1 ?

Ett ytterligare förslag till fortsatt forskning är att intervjua lärare som arbetar i förskoleklass om vilka avsikter de har med undervisningen då ljuset riktas mot samtalet, läsandet och skrivandet. Detta ger inte min studie något svar på och därför skulle det vara intressant att forska vidare om det. Vad anser lärarna att barnen ska lära i förskoleklass? Hur ska det läras? Varför ska det läras? Med hjälp av vad lär sig barnen? Med hjälp av vem lär de sig? Detta är några av de frågor som kan ligga till grund för att undersöka lärares avsikter och uppfattningar om verksamheten. Hur ser lärare i förskoleklass på barns tidigare erfarenheter? är en annan fråga som är intressant i sammanhanget. Tidigare forskning (se exempelvis Fast, 2007) visar att lärare i förskoleklass kan uppleva en vilsenhet beträffande förskoleklassens uppdrag. En fråga som kan ställas i relation till detta är hur lärare ser på förskoleklassens uppdrag med tanke på att förskoleklassen fått ett eget avsnitt i den senaste utgivna läroplanen (Skolverket, 2016) där förskoleklassens syfte och centrala innehåll finns beskrivet för första gången. Har uppdraget i och med det blivit tydligare?

Ett annat alternativ är att fokusera på förskoleklassverksamheten ur barnens perspektiv, vilket enligt SOU (2010:67) är ett relativt outforskat område. Frågorna ovan skulle även kunna användas för att intervjua barn 
som går i förskoleklass. Vad tycker till exempel barn att de ska lära sig i förskoleklass? Varför ska det läras? Med hjälp av vem anser barn att de lär sig? 


\section{Referenser}

Ackesjö, H. (2010). Läraridentiteter i förskoleklass. Berättelser från ett gränsland. Lic.-avh. Göteborg: Göteborgs universitet.

Adams, J. M. (1990). Beginning to read. Thinking and learning about Print. Cambridge: The MIT Press.

Alderson, P. (1995). Listening to children: children, ethics and social research. Barkingside: Barnados.

Alvesson, M., \& Sköldberg, K. (2008). Tolkning och reflektion. Vetenskapsfilosofi och kvalitativ metod. Lund: Studentlitteratur.

Baker, S., Santoro, L., Chard, D., Fien, H., Park, Y., \& Otterstedt, J. (2013). An evaluation of an explicit read aloud intervention taught in whole-classroom formats in first grade. Elementry School Journal, 11, 331-358.

Bakhtin, M. M. (1981). The Dialogic imagination. Austin: University of Texas Press.

Barton, D. (2007). Literacy. An introduction to the ecology of written language. Malden, Oxford: Blackwell.

Beach, D. (2008). Ethnography and representation: About representations for criticism and change through ethnography. In G. Walford (Ed.), How to do educational ethnography. (pp. 165-182). London: Tufnell Press.

Björk, M., \& Liberg, C. (2006). Vägar in i skriftspråket. Tillsammans och på egen hand. Stockholm: Natur och Kultur.

Björklund, E. (2008). Att erövra litteracitet. Små barns kommunikativa möten med berättande, bilder, text och tecken i förskolan. Diss. Göteborg: Göteborgs universitet.

Bradley, L., \& Bryant, P. (1983). Categorizing sounds and learning to read - A causal connection. Nature, 301, 419-421.

Braun, V., \& Clarke, V. (2006). Using thematic analysis in psychology. Qualitative Research in Psychology 3, 77-101.

Braze, D., Tabor, W., Shankweiler, D., \& Mencl, E. (2007). Speaking up for vocabulary. Reading skill differences in young adults. Journal of Learning Disabilities, 40, 226-243.

Bryman, A. (2011). Samhällsvetenskapliga metoder. Malmö: Liber AB.

Bryntse, A.-M., \& Palmkvist, A. (1996). Trulle: Trulle lärarbok. Malmö: Gleerups. 
Bus, A. G., \& Van Ijzendoorn, M. H. (1999). Phonological Awareness and Early Reading: A meta-analysis of experimental training studies. Journal of Educational Psychology, 91, 403-414.

Chapin, S. H., \& O`Connor, C. (2007). Academically productive talk: Supporting students' learning in mathematics. In W. G. Martin, \& M. E. Strutchens (Eds.), The Learning of mathematics. sixty-ninth yearbook (pp. 113-128). Danvers: The National Council of Teachers of Matematics.

Clay, M. (1966). Emergent reading behaviour. Diss. Aukland: Aukland university.

Clay, M. (1975). What did I write? Beginning writing behaviour. London: Heinemann Educational Books.

Cochran-Smith, M. (1984). The making of a reader. New Jersey: Ablex Publishing Corporation.

Dahllöf, U. (1967). Skoldifferentiering och undervisningsförlopp. Stockholm: Almqvist \& Wiksell.

Dahllöf, U. (2002). Nålsögon, styrgrupper eller individanpassat ramsystem. Pedagogisk forskning i Sverige, 7, 218-232.

Dalby, M., Elbro, C., Jansen, M., \& Krogh, T. (1992). Boken om leasing. Köpenhamn: Danmarks pedagogiska institut.

Davidsson, B. (2002). Mellan soffan och katedern. En studie av hur förskollärare och grundskollärare utvecklar pedagogisk integration mellan förskola och skola. Diss. Göteborg: Göteborgs universietet.

De Temple, J. M., \& Snow, C. E. (2001). Conversations about literacy: Social mediation of psycholingvistic activity. In L. Verhoeven, \& C. E. Snow (Eds.), Literacy and motivation reading engagement in individuals and groups (pp. 55-69). Mahwah, NJ: Lawrence Erlbaum Associates Publishers.

Delamont, S. (2012). "Traditionell" ethnography: peopled ethnography for luminous description. In S. Delamont (Ed.), Handbook of qualitative research in education (pp. 342-363). Cheltenham: Edward Elgar Publishing Limited.

Duke, N. K., \& Pearson, P. D. (2002). Effective practices for developing reading comprehension. In A. Farstrup, \& S. J. Samuels (Eds.), What research has to say about reading instruction (pp. 205-242). Newark: International Reading Association.

Dysthe, O. (1996). Det flerstämmiga klassrummet. Att skriva och samtala för att lära. Lund: Studentlitteratur. 
Ehri, L., Nunes, S. R., Willows, D. M., Schuster, B. V., \& YaghoubZadeh, Z. S. (2001). Phonemic awareness instruction helps children learn to read: Evidence from the National Readning Panel's meta-analysis. Readning Research Quarterly, 36, 250-287. Einarsson, C. (2003). Lärares och elevers interaktion $i$ klassrummet: betydelsen av kön, ålder, ämne och klasstorlek samt lärares uppfattningar om interaktion. Diss. Linköping: Linköpings universitet.

Einarsson, J., \& Hultman, T. G. (1984). Gormorgon pojkar och flickor. Om språk och kön i skolan. Stockholm: Liber.

Elleman, A. M., Lindo, E. J., Morphy, P., \& Compton, D. (2009). The impact of vocabulary instruction on passage-level comprehension of school-age children: A meta-analysis. Journal of Research on Educational Effectiveness, 2, 1-44.

Elwér, Å. (2014). Early predictors of reading comprehension difficulties. Diss. Linköping: Linköpings universitet.

Eriksen Hagtvet, B. (2009). När riskbarn möter klassrumspraxis. i L. Bjar, \& A. Frylmark (red.), Barn läser och skriver (ss. 169-192). Lund: Studentlitteratur.

Eriksen Hagtvet, B., \& Pálsdóttir, H. (1993). Lek med språket. Stockholm: Natur och Kultur.

Fangen, K. (2005). Deltagande observation. Malmö: Liber AB.

Fast, C. (2007). Sju barn lär sig läsa och skriva. Familjeliv och populärkultur $i$ möte med förskola och skola. Diss. Uppsala: Uppsala universitet.

Gannerud, E., \& Rönnerman, K. (2006). Innehåll och innebörd $i$ lärares arbete i förskola och skola. En fallstudie ur ett genusperspektiv. Diss. Göteborg: Göteborgs universitet.

Gillen, J., \& Hall, N. (2003). The emergence of early childhood literacy. In N. Hall, J. Larson, \& J. Marsh (Eds.), Handbook of early childhood literacy (pp. 3-12). London: Sage Publications.

Gillon, G. T. (2004). Phonological awareness. From research to practice. New York: The Guilford press.

Goswami, U., \& Bryant, P. (1990). Phonological skills and learning to read. Hove: Lawrence Erlbaum .

Gough, P., \& Tunmer, W. (1986). Decoding, reading and reading disability. Remedial and Special Education, 7, 6-10.

Granström, K. (2003). Arbetsformer och dynamik i klassrummet. i S. Selander (red.), Kobran, nallen och majjen. Tradition och förnyelse 
$i$ svensk skola och skolforskning (ss. 223-243). Stockholm: Myndigheten för skolutveckling.

Granström, K. (2004). Om tillförlitligheten i observationer inom forskning och psykologisk praktik. Nordisk Psykologi, 56, 289303.

Granström, K. (2005). Group phenomena and classroom management. A Swedish perspective. In C. M. Evertson, \& C. S. Weinstein (Red.), Handbook for classroom management research practise and contemporary issues (pp. 1141-1160). New York: Erlbaum.

Gustafsson, K., \& Mellgren, E. (2005). Barns skriftspråkande - att bli en skrivande och läsande person. Diss. Göteborg: Acta Universitatis Gothoburgensis.

Hammersley, M., \& Atkinson, P. (2007). Ethnography. Principles in practice. London: Routhledge.

Hargreaves, E., McCallum, B., \& Gipps, C. (2000). Teacher feedback strategies in primary classroom - new evidence. In S. Askew (Ed.), Feedback for learning (pp. 21-31). London: Routledge.

Hatcher, P., Hulme, C., \& Ellis, A. (1994). Ameliorating early reading by integrating the teaching of reading and phonological skills: the phonological linkage hypothesis. Child Development, 65, 4157.

Hattie, J. (2009). Visible Learning. A Synthesis of over 800 metaanalyses relating to achievment. London \& New York: Routledge.

Heath, S. B. (1983). Ways with words: language, life and work in communities and classroms. Cambridge: Cambridge University Press.

Heath, S. B., \& Street, B. (2008). On ethnography. Approaches to language and literacy research. New York: Teachers College Press.

Heikkilä, M. (2006). Kommunikativa resurser för lärande. Barns gester, blickar och tal $i$ tre skolmiljöer. Diss. Uppsala: Uppsala universitet.

Heikkilä, M., \& Sahlström, F. (2003). Om användning av videoinspelning i fältarbete. Pedagogisk forskning i Sverige, 8, 24-41.

Hjälme, A. (1999). Kan man bli klok på läsdebatten? Analys av en pedagogisk kontrovers. Solna: Ekelund.

Hoien, T., \& Lundberg, I. (1999). Dyslexi. Från teori till praktik. Stockholm: Natur och Kultur. 
Hopkins, D. (2008). A teacher's guide to classroom research. Buckingham: Open University Press.

Howitt, D. (2010). Introduction to qualitative methods in psychology. London: Prentice Hall.

Jönsson, K. (2007). Litteraturarbetets möjligheter. En studie av barns läsning $i$ årskurs F-3. Diss. Malmö: Malmö högskola.

Kilborn, W., \& Lundgren, U. P. (1975). A contribution to the analysis of arithmetic teaching and learning. Bielefeld: Institut fur Diktaktik der Mathematik .

Kirk, C., \& Gillon, G. T. (2009). Integrated morphological awareness intervention as a tool for improvning literacy. Languages, Speech and Hearing Services in Schools, 40, 341-351.

Kullberg, B. (2007). Emergent Literacy. Femton svenska forskares tankar om barns skriftspråkslärande 2006. Göteborg: Göteborgs universitet.

Lago, L. (2014). "Mellanklass kan man kalla det". Om tid och meningsskapande vid övergången från förskoleklass till årskurs ett. Diss. Linköping: Linköpings universitet.

Langer, J. A. (1995). Envisioning literature. Literacy understanding and literature instruction. New York: Teachers College Press.

Lankshear, C., \& Knobel, M. (2003). New literacies: Changing knowledge and classroom learning. Buckingham: Open University Press.

Larsson, S. (2005). Om kvalitet i kvalitativa studier. Nordisk Pedagogik, 25, 16-35.

Leppänen, U., Aunola, K., \& Nurmi, J. (2005). Beginning readers'reading performance and reading habits. Journal of Research in Reading, 28, 383-399.

Liberg, C. (1990). Learning to read and write. Diss. Uppsala: Uppsala universitet.

Liberg, C. (2003). Bilder av läs- och skrivutveckling i samspel. i S. Selander (red.), Kobran, nallen och majjen. Tradition och förnyelse $i$ svensk skola och skolforskning (ss. 205-222). Stockholm: Myndigheten för skolutveckling.

Liberg, C. (2006). Hur barn lär sig läsa och skriva. Lund: Studentlittertur.

Liberg, C. (2007a). Språk och kommunikation. i C. Liberg, K. Hyltenstam, M. Myrberg, C. Frykholm, M. Hjort, G. Nordström, \& U. Wiklund (red.), Att läsa och skriva. Forskning 
och beprövad erfarenhet. (ss. 7-23). Stockholm: Myndigheten för skolutveckling.

Liberg, C. (2007b). Läsande, skrivande och samtalande. i C. Liberg, K. Hyltenstam, M. Myrberg, C. Frykholm, M. Hjort, G. Nordström, \& U. Wiklund (red.), Att läsa och skriva. Forskning och beprövad erfarenhet. (ss. 25-44). Stockholm: Myndigheten för skolutveckling.

Liberg, C. (2008). Läs- och skrivutveckling och ett utökat läraruppdrag. Hämtad $31 \quad$ oktober 2016 från www.ep.liu.se/ecp/032/004/ecp0832004.pdf.

Liberg, C., \& Säljö, R. (2014). Grundläggande färdigheter: att bli medborgare. i U. P. Lundgren, R. Säljö, \& C. Liberg (red.), Lärande skola bildning. Grundbok för lärare (ss. 357-377). Stockholm: Natur och Kultur.

Liberg, C., Folkeryd Wiksten, J., \& Af Geijerstam, Å. (2012). Swedish - An updated school subject? Education Inquiry, 3, 477-493.

Lundberg, I. (2007). Bornholmsmodellen. Vägen till läsning: Språklekar $i$ förskoleklass. Stockholm: Natur och Kultur.

Lundberg, I., Frost, J., \& Petersen, O. (1988). Effects of an intensive program for stimulating phonological awareness in preschool. Readning Research Quarterly, 23, 263-284.

Lundberg, I., Larsman, P., \& Strid, A. (2012). Development of phonological awareness during the preschool year: the influence of gender and socio-ecnonomic status. Reading and Writing. An Interdisciplinary Journal, 25, 305-320.

Lundgren, U. P. (1972). Frame factors and the teaching process. A contribution to curriculum theory and theory on teaching. Diss. Stockholm: Almqvist \& Wiksell.

Lundgren, U. P. (1989). Att organisera omvärlden. En introduktion till läroplansteori. Stockholm: Liber .

Mc Cormack, R. L., \& Pasquarelli, S. L. (2010). Teaching reading. Strategies and resources for grades K-6. New York \& London: The Guilford Press.

McKeown, M. G., Beck, I., \& Blake, R. (2009). Rethinking Reading Comprehension Instruction: A Comparison of Instruction for Strategies and Content Approaches. Reading Research Quarterly, 44, 218-253.

Mehan, H. (1979). Learning lessons: social organization in the classroom. Cambridge, Mass: Harvard U.P. 
Mercer, N. (1995). The guided construction of knowledge: talk among teachers and learners. Clevedon: Multilingual Matters.

Moats, L. C. (2009). Knowledge foundations for teaching reading and spelling. Reading $\mathcal{E}$ Writing. An interdisciplinary Journal, 22, 379-399.

Mohammad Reza, A., \& Hairul Nizam, I. (2012). Reciprocal teaching strategy as an important factor of improvning reading comprehension. Journal of Studies in Education, 2, 153-173.

Myers, P. A. (2005). The princess storyteller, Clara Clarifier, Quincy Questioner, and the wizard: Reciprocal teaching adapted for kindergarten students. The Reading Teacher, 59, 314-324.

Myrberg, M. (2001). Att förebygga och möta läs- och skrivsvårigheter. En forskningsöversikt på uppdrag av Skolverket. Stockholm: Skolverket.

Myrberg, M. (2003). Att skapa konsensus om skolans insatser för att motverka läs- och skrivsvårigheter. Stockholm: Lärarhögskolan.

National Reading Panel. (2000). Teaching children to read: An evidence based assessment of the scientific research literature reading and its implications for readning instruction: Reports of the subgroups. Rockville, MD: NICHD Clearinghouse.

O'Connor, C., \& Michaels, S. (2007). When is dialogue dialogic. 'Human Development, 50, 275-285.

Oczkus, L. D. (2003). Reciprocal teaching at work. Strategies for improving reading comprehension. Newark: International Reading Association.

Palincsar, A. S., \& Brown, A. L. (1984). Reciprocal teaching of comprehension-fostering and comprehension-monitoring activities. Cognition and Instruction, 1, 117-175.

Pérez Prieto, H., Sahlström, F., \& Melander, H. (2003). Från förskola till skola - berättelser från ett forskningsprojekt. Uppsala: Pedagogiska inst, Univ., 2003.

Pilonieta, P., \& Medina, A. L. (2009). Reciprocal teaching for the primary grades: "We can do it, too!". Reading Teacher, 63, 120129.

Pressley, M. (2006). Reading instruction that works: The case for balanced teaching. New York: Guilford.

Proposition. (1997/98:4). Läroplan för det obligatoriska skolväsendet, förskoleklassen och fritidshemmet m.m. Stockholm: Utbildningsdepartementet. 
Proposition. (1997/98:6). Förskoleklass och andra skollagsfrågor. Stockholm: Utbildningsdepartementet.

Proposition. (2009/10:165). Den nya skollagen: för kunskap, valfrihet och trygghet. Stockholm: Utbildningsdepartementet.

Roberts, K. L. (2013). Comprehension strategy instruction during parent-child shared reading: An intervention study. Literacy Research and Instruction, 52, 106-129.

Rogoff, B. (1990). Apprenticeship in thinking. Cognitive development in social context. New York: Oxford University Press.

Sahlström, F. (2002). The interactional organization of hand raising in classroom interaction. Jourmal of Classroom Interaction, 37, 47-57.

Sahlström, F. (2008). Från lärare till elever, från undervisning till lärande: utvecklinslinjer $i$ svensk, nordisk och internationell klassrumsforskning. Stockholm: Vetenskapsrådet.

Sandberg, G. (2012). På väg in i skolan. Om villkor för olika barns delaktighet och skriftspråkslärande. Diss. Uppsala: Uppsala universitet.

Scarborough, H. S. (1998). Early identification of children at risk for readning disabilities. Phonological awareness and some other promising predictors. In B. K. Shaprio, P. J. Accardo, \& A. J. Capute (Eds.), Specific Reading Disability. A View of the Spectrum (pp. 75-119). Timonium: MD: York Press.

Schoonen, R., \& Verhallen, M. (2008). The assessment of deep word knowledge in young first and second language learners. Language Testing, 25, 211-236.

Scribner, S., \& Cole, M. (1981). The psychology of literacy. Cambridge: Harvard University Press.

SFS. (2010:800). Skollag. Stockholm: Utbildningsdepartementet.

Simeonsdotter Svensson, A. (2009). Den pedagogiska samlingen $i$ förskoleklassen. Barns olika sätt att erfara och hantera svårigheter. Diss. Göteborg: Göteborgs universitet.

Sinclair, J., \& Coulthard, R. M. (1975). Towards an analysis of discourse. London: Oxford University Press.

Skelton, T. (2008). Research with children and young people: exploring the tension between ethics, competence och participation. Children's Geographies, 6, 21-36.

Skolinspektionen. (2015:03). Undervisning i förskoleklass. Stockholm: Skolinspektionen. 
Skolverket. (2000). Förskoleklass - 6-åringarnas skolform? Integrationen förskoleklass - grundskola - fritidshem. Stockholm: Skolverket.

Skolverket. (2001). Att bygga en ny skolform för 6-åringar: Om integrationen förskoleklass, grundskola och fritidshem. Stockholm: Skolverket.

Skolverket. (2007). Vad händer med läsningen? En kunskapsöversikt om läsundervisningen i Sverige 1995-2007. Rapport 304. Stockholm: Skolverket.

Skolverket. (2009). Skolverkets lägesbedömning 2009. Förskoleverksamhet, skolbarnsomsorg, skola och vuxenutbildning. Rapport 337. Stockholm: Fritzes.

Skolverket. (2011). Läroplan för grundskolan, förskoleklassen och fritidshemmet 2011: Lgr11. Stockholm: Skolverket.

Skolverket. (2014). Förskoleklassen - uppdrag, innehåll och kvalitet. Stockholm: Skolverket.

Skolverket. (2015). Skolverkets lägesbedömning 2015. Rapport 421. Stockholm: Skolverket.

Skolverket. (2016). Läroplan för grundskolan, förskoleklassen och fritidshemmet 2011: reviderad 2016. Stockholm: Skolverket.

Skoog, M. (2012). Skriftspråkande i förskoleklass och årskurs 1. Diss. Örebro: Örebro universitet.

Snow, C. E., \& Juel, C. (2007). Teaching children to read: What do we know about how to do it? In M. J. Snowling, \& C. Hulme (Eds.), The science of reading: a handbook. (pp. 501-520). Malden, Ma: Blackwell publishing.

Snow, C. E., Burns, M. S., Griffin, P., \& National academy of sciences - national research council, W. E. (1998). Preventing reading difficulties in young children. Washington, D. C.: National Academy Press.

SOU. (1997:21). Växa i lärande. Förslag till läroplan för barn och unga 616 år. Stockholm: Fritzes.

SOU. (2008:109). En hållbar lärarutbildning. Betänkande av utredning om en ny lärarutbildning. Stockholm: Fritzes.

SOU. (2010:67). I rättan tid?: Om ålder och skolstart. Stockholm: Fritzes.

SOU. (2015:81). Mer tid för kunskap - förskoleklass, förlängd skolplikt och lovskola. Stockholm: Fritzes.

Sparrman, A. (2005). Video recording as interaction: participant observation of children's everyday life. Qualitative Research in Psychology, 2, 241-255. 
Spörer, N., Brunstein, J. C., \& Kieschke, U. (2008). Improving student's reading comprehension skills: Effects of strategy instruction and reciproacal teaching. Learning and Instruction, 19, 272-286.

Stanovich, K. (2000). Progress in understanding reading. Scientific foundations and new frontiers. New York: Guilford Press.

Street, B. V. (1984). Literacy in theory and practice. Cambridge: Cambridge University Press.

Street, B. V. (2000). Literacy events och literacy practices. Theory and practice in the new literacy studies. In M. Martin-Jones, \& K. E. Jones (Eds.), Multilingual literacies. Readning and writing Different Worlds. (pp. 16-29). Amsterdam: John Benjamins Publishing Company.

Svenska språknämnden. (2005). Svenska skrivregler, utgiven av svenska språknämnden. Stockholm: Liber AB.

Säljö, R. (2000). Lärande i praktiken. Ett sociokulturellt perspektiv. Stockholm: Prisma.

Säljö, R. (2003). Föreställningar om lärande och tidsandan. i S. Selander (red.), Kobran, nallen och majjen. Tradition och förnyelse $i$ svensk skola och skolforskning (ss. 71-89). Stockholm: Myndigheten för skolutveckling.

Säljö, R. (2013). Lärande och kulturella redskap. Om lärprocesser och det kollektiva minnet. Lund: Studentlitteratur AB.

Taylor, D. (1983). Family literacy. Young children learning to read and write. Portsmouth: Heinemann Educational Books.

Teale, W., \& Sulzby, E. (1986). Emergent literacy. writing and reading. Norwood, Ney Jersey: Ablex Publishing Corporation.

UNICEF. (2009). Barnkonventionen: FN:s konvention om barnets rättigheter. Stockholm: UNICEF Sverige.

Utbildningsdepartementet. (2015). Uppdrag till Statens skolverk om förtydligande av förskoleklassens och fritidshemmets uppdrag m.m. U2015/191/S. Stockholm: Utbildningsdepartementet.

Weizman, Z. O., \& Snow, C. E. (2001). Lexical input as related to children's vocabulary acquistion: Effects of sophisticated exposure and support for meaning. Development Psychology, $37,265-279$.

Wells, G. (2007). Semiotic mediation, dialogue and the construction of knowledge. Human Development, 50, 244-274.

Wells, G., \& Aruz, R. M. (2006). Dialogoues in the classroom. The Journal of the Learning Sciences, 15, 379-428. 
Vellutino, F. R. (2003). Individual differences as sources of variability in reading comprehension in elementary school children. In A. P. Sweet, \& C. E. Snow (Eds.), Rethinking reading comprehension (pp. 51-81). New York: Guilford Press.

Vellutino, F. R., \& Scanlon, D. M. (1986). Experimental evidence for the effects of instructional bias on word identification. Exeptional Children, 53, 145-155.

Wertsch, J. V. (1985). Vygotsky and the social formation of mind. Cambridge, Massachusetts, London: Harvard University Press.

Vetenskapsrådet. (2011). God forskningssed. Stockholm: Vetenskapsrådet. Hämtad 4 november 2016 från https:/ / publikationer.vr.se/produkt/god-forskningssed/.

Vetenskapsrådet. (2015). Kunskapsöversikt om läs- och skrivundervisning för yngre elever. Stockholm: Vetenskapsrådet.

Wolter, J. A., Wood, A., \& D'zatko, K. W. (2009). The influence of morphological awareness on the literacy development of firstgrade children. Language, Speech and Hearing Services in Schools, 40, 286-298.

Wood, D., Bruner, J., \& Ross, G. (1976). The role of tutoring in problem solving. Journal of Child Psychology and Psychiatry, 17, 89-100.

Vygotskij, L. S. (1934/2010). Tänkande och språk. Göteborg: Bokförlaget Daidalos AB.

Vygotskij, L. S. (1978). Mind in society. The development of higher psychological processes. Cambridge, Massachusetts, London: Harvard University Press. 


\section{Tidigare utgivna rapporter}

240 Westlund, Ingrid. LÄXBERÄTTELSER. Läxor som tid och uppgift. Oktober 2004.

241 Pedersen, Jens. VÄGAR TILL VÄRDERINGAR OCH VÄRDEN. Skolans sociala fostran i läroplanstexter och pedagogisk praktik. Oktober 2004. (Licentiatavhandling)

242 Colnerud, Gunnel \& Hägglund, Solveig (red). ETISKA LÄRARE MORALISKA BARN. Forskning kring värdefrågor i skolans praktik. Värdepedagogiska texter II. November 2004.

243 Matwejeff, Susanna. SVENSKFÖDDA ADOPTERADES SÖKPROCESS. Januari 2005. (Licentiatavhandling)

244 Samuelsson, Joakim. LÄRARSTUDENTERS ERFARENHETER AV MATEMATIKUNDERVISNING. Vad händer med elever när de inte förstår? Maj 2005.

245 Öfverström Christel. UPPLEVELSE, INLEVELSE OCH REFLEKTION drama som en aktiv metod i lärandet. September 2006. (Licentiatavhandling) ISBN: 91-85643-71-8

246 Eriksson Gustavsson Anna-Lena, Samuelsson, Joakim. DIDAKTISKA SAMTAL I SPECIALPEDAGOGISKA KONTEXTER. En studie av undervisning i grundläggande svenska och matematik. Februari 2007. ISBN: 978-91-85715-68-8.

247 Österström, Stefan. OM KONSTEN ATT ÖVERBRYGGA GRÄNSER. En fallstudie om kommunal äldreomsorg och samspelet med andra organisationer. Maj 2007. ISBN: 978-91-85895-04-5.

248 Engström, Arne, Magne, Olof. MEDELSTA-MATEMATIK IV. En empirisk analys av Skolverkets förslag till mål att uppnå i matematik för årskurs 3. Mars 2008. ISBN: 978-91-7393-918-8.

249 Thornberg, Robert. Vilka värden elever enligt lärare ska få med sig från skolan. April 2008. ISBN: 978-91-7393-909-6.

250 Colnerud, Gunnel Karlsson, Ingrid Szklarski, Andrzej. ALLTID REDO Lärarstudenters handlingsberedskap för varierande uppgifter i klassrummet.2008. ISBN: 978-91-7393-784-9.

251 Szczepanski, Anders. HANDLINGSBUREN KUNSKAP Lärares uppfattningar om landskapet som lärandemiljö. 2008. ISBN: 978-91-7393-889-1. 
252 Thornberg, Robert. Ett resursteams samverkan med skola, elever och föräldrar förtjänster, hinder och utmaningar. 2009. ISBN: 978-91-7393-599-9 (Finns bara i Pdf-format).

253 Hammar Chiriac, Eva. SLÄPP TANKARNA LOSS - DET ÄR NYTT. Kvalitetsgranskning av ett reformarbete. Ny speciallärarutbildning. 2009. ISBN: 978-91-7393-541-8

254 Eriksson Gustavsson, Anna-Lena, Holme Lotta. ATT GÖRA OLIKA LIKA. Universitetslärares uppfattningar om och erfarenheter av undervisning av funktionshindrade studenter. 2009. ISBN: 978-91-7393-529-6

255 Lönebrink, Thomas. PROCESSER I VÄXELVERKAN. En grundad teoretisk modell om landstingskommunal samverkan för personer med psykiska funktionshinder. 2010 (Licentiatavhandling). ISBN: 978-91-7393-242-4

256 Harlin, Eva-Marie. Överraskning och Reflektion. Lärarstudenters lärande från egen undervisning. 2010 (Licentiatarbete). ISBN: 978-91-7393-228-8

257 Eriksson Gustavsson, Anna-Lena. ”Det är tufft att plugga... men jag känner att jag klarar det”. En studie om akademiska studier och skriftspråkliga svårigheter. 2011. ISBN: 978-91-7393-183-0

258 Samuelsson, Joakim. Den skicklige matematikläraren. 2013. ISBN: 978-917519-609-1

259 Fredriksson Mårtensson, Åsa. Handledare och handledning - gymnasial yrkesutbildning på förskola. 2014 (Licentiatavhandling). ISBN: 978-91-7519269-7

260 Wallin, Jessica. Entreprenörskap i skolan. Formulering och transformering av GY11 inom gymnasieskolans hantverksprogram. 2014. (Licentiatarbete). ISBN: 978-91-7519-263-5

261 Alm, F, Jungert, T och Thornerg, R: Nyantagna lärarstudenters motiv, motivation, självtillit och akademiska engagemang. 2014. ISBN: 978-91-7519384-7 (finns bara i elektronisk version).

262 Kerekes, Klara. Undervisning om växande geometriska mönster. En variationsteoretisk studie om hur lärare behandlar ett matematiskt innehåll på mellanstadiet. 2014. (Licentiatavhandling). ISBN: 978-91-7519-135-5

263 Bergseth, Brita. Vägledande eller vilseledande? Kvalitetsmätning och ranking av universitet och högskolor. 2015 (Licentiatavhandling). ISBN: 978-91-7685937-7

264 Sveider, Cecilia. Lärares och elevers användande av laborativt material i bråkUndervisningen i skolår år 4-6. Vad görs möjligt för eleverna att erfara? 2016 (Licentiatavhandling). ISBN: 978-7685-827-1 